UNIVERSIDADE DE SÃO PAULO

ESCOLA DE ENFERMAGEM DE RIBEIRÃO PRETO

EDILAINE ASSUNÇÃO CAETANO

Participação de mastectomizadas em um grupo de reabilitação: benefícios e barreiras percebidos 


\title{
Participação de mastectomizadas em um grupo de reabilitação: benefícios e barreiras percebidos
}

\author{
Dissertação apresentada à Escola de \\ Enfermagem de Ribeirão Preto da \\ Universidade de São Paulo para obtenção do \\ título de Mestre em Ciências, Programa de \\ Pós-Graduação em Enfermagem em Saúde \\ Pública \\ Linha de pesquisa: Assistência à saúde da \\ mulher no ciclo vital \\ Orientadora: $\operatorname{Prof}^{\mathrm{a}} \operatorname{Dr}^{\mathrm{a}}$ Marislei Sanches \\ Panobianco
}


Autorizo a reprodução e divulgação total e parcial deste trabalho, por qualquer meio convencional ou eletrônico, para fins de pesquisa desde que citada a fonte.

Catalogação da Publicação

Serviço de Documentação de Enfermagem

Escola de Enfermagem de Ribeirão Preto

Universidade de São Paulo

Caetano, Edilaine Assunção Caetano

Participação de mastectomizadas em um grupo de reabilitação: benefícios e barreiras percebidos

102 f. : il. ; 30cm

Dissertação de Mestrado apresentada à Escola de Enfermagem de Ribeirão Preto/USP.

Orientadora: Panobianco, Marislei Sanches.

1. Câncer de Mama. 2. Reabilitação. 3. Enfermagem. 
CAETANO, Edilaine Assunção

PARTICIPAÇÃO DE MASTECTOMIZADAS EM UM GRUPO DE REABILITAÇÃO:

BENEFÍCIOS E BARREIRAS PERCEBIDOS

Dissertação apresentada à Escola de

Enfermagem de Ribeirão Preto da

Universidade de São Paulo para obtenção do título de Mestre em Ciências, Programa de Pós-Graduação em Enfermagem em Saúde Pública

Aprovado em:

\section{Comissão Julgadora}

Prof. Dr.

Instituição: Assinatura:

Prof. Dr.

Instituição: Assinatura:

Prof. Dr. Instituição: Assinatura: 


\section{DEDICATÓRIA}

A Deus, meu refúgio e fortaleza, onde encontro forças para não desanimar.

Às mulheres do MUCAMA, necessitadas de cuidados, mas que em muito nos ensinam, por me fazer perceber que precisamos dos sonhos para viver, como este trabalho concluído.

À minha mãe, exemplo de fé e sabedoria, pela serenidade e por nunca medir esforços por mim, sempre imprescindível para minha formação acadêmica e pessoal; ao meu pai que, mesmo não estando mais entre nós, sempre foi exemplo de luta e dedicação.

Aos meus irmãos, pelo apoio incondicional.

À minha sobrinha Jessica, que me enche de luz e felicidade, obrigada pela calma e respeito.

À minha enteada Isabella, por me proporcionar tantos momentos de alegria. "Tem jeito não" de eu viver sem você.

Ao meu companheiro, amigo, confidente e inspirador, Sérgio, que sempre me incentivou para a realização dessa trajetória, me amparando nos momentos difíceis e vibrando pelas minhas vitórias. Obrigada pela paciência e pela compreensão. Sem você nada seria possivel. 


\section{AGRADECIMENTTOS}

À minha orientadora, Profa $\operatorname{Dr}^{a}$ Marislei Sanches Panobianco, muito obrigada, por ter me acompanhado com muita confiança em meu potencial, permitindo que nosso trabalho se desenvolvesse com liberdade e responsabilidade de escothas. Obrigada por seu exemplo de vida e de determinação.

À Prof ${ }^{a} \mathscr{D r}^{a}$ Clícia Valim Cortes Gradim, coordenadora do projeto $\mathcal{M}$ UCAMA, por ceder gentilmente espaço para realização deste trabalho, por sempre me acompanhar e fazer acreditar que com trabalho e dedicação tudo se pode alcançar;

À Profa $\mathfrak{D r}^{a}$ Marli Villela Mamede, pelos infinitos ensinamentos e pela paciência.

Às professoras $\mathcal{D r}^{a}$ Ana Maria de Almeida e $\mathcal{D r}^{a}$ Thaís de Oliveira Gozzo, pelos ricos momentos de aprendizagem no grupo de estudos.

Às entrevistadas, imprescindíveis na execução e na conclusão da pesquisa, pelo acolhimento e por compartilhar comigo seus saberes e suas vivências.

Aos participantes do Programa de Enfermagem em Saúde Pública e Grupo de Pesquisa Enfermagem, Mulher e Saúde, por apontar tantas possibilidades construcionistas que contribuíram com o saber fazer pesquisa.

Aos meus irmãos Cristiane, pelas orações e por não me deixar desanimar; Kátia, pelo exemplo de garra e pela escuta; Ronan, pelo carinho e torcida.

À minha cunhada Yolanda, sempre confiante em minha dedicação.

Às companheiras de mestrado Aline, Simone, Marceila, Talita, Pamina, Bárbara, Michelly, pela amizade, pelo companheirismo e pelo respeito;

Aos funcionários do Serviço de Pós-graduação Kethleen, Flávia, Carla e Vlisses, pelos atendimentos prestados com excelência e simpatia;

À funcionária Shirley, sempre tão atenciosa e prestativa, pelo acolfimento. 
À minha amiga Fernanda, incansável no auxílio em minha trajetória, pelo carinho e pelo incentivo.

Às minhas queridas amigas Gisele, Kitéria e Natália, pela torcida, por me escutarem e auxiliarem nos momentos dificeis e por compartilharem de minhas alegrias.

À Profa Dra $^{a}$ Eliza Maria Rezende Dázio, que foi compreensiva e apoiadora na construção deste ideal.

À Coordenação de Aperfeiçoamento de Pessoal de Nível Superior - CAPES, pelo apoio financeiro.

Aos amigos, que de alguma forma me ajudaram e estiveram presentes nesta caminhada.

Aos demais familiares, em especial a Tïa Conceição, por sempre estarem presentes em meu coração.

A vocês, meu muito obrigada! 
"É fundamental diminuir a distância entre o que se diz e o que se faz, de tal maneira que num dado momento a sua fala seja a sua prática” Paulo Freire. 


\section{RESUMO}

CAETANO, E. A. Participação de mastectomizadas em um grupo de reabilitação: benefícios e barreiras percebidos. 2012. 102 f. Dissertação (Mestrado) - Escola de Enfermagem de Ribeirão Preto, Universidade de São Paulo, Ribeirão Preto, 2012.

Estudo de abordagem qualitativa, que objetivou analisar a percepção de mulheres com câncer de mama acerca da seriedade da doença, de sua suscetibilidade a ela e dos benefícios e barreiras para a participação em grupos de reabilitação. Realizado no Núcleo de Ensino, Pesquisa e Extensão Mulher e Câncer de Mama - MUCAMA, em Alfenas - MG, utilizou como referencial teórico o Modelo de Crenças em Saúde e conceitos da Teoria de Campo de Kurt Lewin. Participaram 08 mulheres operadas por câncer de mama, que compareciam regularmente ao serviço, há no mínimo três meses antes da coleta, entre maio e julho de 2011. Os dados foram coletados por meio de grupos focais e entrevistas, utilizando um roteiro semiestruturado e analisados pela Análise de Conteúdo Temática. Emergiram dos relatos dois temas e as respectivas categorias: Mulheres portadoras de câncer de mama: percepções acerca da suscetibilidade e seriedade da doença - crenças sobre a suscetibilidade ao câncer de mama; a visão da seriedade do câncer de mama; os estímulos para a ação: a busca de apoio no grupo de reabilitação - e Benefícios e barreiras percebidos na decisão sobre participar do grupo de reabilitação - o retorno às atividades cotidianas e a reabilitação psicossocial; percepção das dificuldades para participar do grupo e/ou aderir às atividades propostas. A percepção da suscetibilidade ao câncer de mama foi demonstrada quando as mulheres referiram crer que o câncer não pode ser evitado, independentemente de classe social, raça ou escolaridade. Atribuíram sua ocorrência à repressão de sentimentos e à falta de um comportamento preventivo em saúde. A percepção da seriedade do câncer de mama como uma condição crônica se mostrou ao considerarem a neoplasia estigmatizante. O medo da morte e as consequências dos tratamentos as levaram a promover novos arranjos sociais e familiares. Os estímulos para ação em procurarem o grupo de reabilitação foram o desconforto e as limitações físicas e emocionais, assim como encaminhamentos e recomendações dos profissionais de saúde e conselhos de familiares e membros da rede social. Os benefícios percebidos para participação no grupo foram a melhora física com a possibilidade de retorno às atividades diárias; atendimento gratuito e especializado; vínculo com a equipe multidisciplinar; apoio psicológico; oportunidade de compartilhar experiências, sanar dúvidas e se sentir em meio a "seus iguais”. As barreiras percebidas: dias e horários de atendimentos limitados; afazeres domésticos; espaço físico restrito; necessidade de demandar tempo e disposição para a adesão às atividades. As percepções individuais das entrevistadas acerca do câncer de mama foram influenciadas por suas crenças sobre suscetibilidade e seriedade ao longo de suas experiências com a doença e seus tratamentos, o que as levou a um comportamento em saúde de participarem do grupo de reabilitação porque viram no mesmo um meio para cuidarem de sua saúde, identificando, para isso, maiores benefícios que barreiras.

Palavras-chave: Enfermagem. Reabilitação. Câncer de mama. 


\begin{abstract}
CAETANO, E. A. Participation in a group of mastectomy rehabilitation: benefits and perceived barriers. 2012. 102 p. Dissertation (MSc) - Nursing School of Ribeirão Preto, Universidade de São Paulo, Ribeirão Preto, 2012.

A qualitative study, which aimed to analyze the perception of women with breast cancer about the seriousness of the illness, their susceptibility to it and the benefits and barriers to participation in rehabilitation groups. Held at the Center of Teaching and Research Women and Breast Cancer - MUCAMA in Alfenas - MG, was used as theorical reference the Health Belief Model and the concepts of the Field Theory of Kurt Lewin. Participated 8 women operated of breast cancer who regularly attended the service, at least three months prior the collection, between May and July 2011. Data were collected through focus groups and interviews using a semi-structured guide, and were analyzed by qualitative analysis. Two themes emerged from the reports and their categories: Women with breast cancer: perceptions of susceptibility and seriousness of the illness - beliefs about susceptibility of breast cancer; the view of the seriousness of breast cancer; stimuli for action: the search for support in the rehabilitation group and perceived barriers and benefits in deciding to participate in the rehabilitation group - the return to everyday activities and psychosocial rehabilitation; perception of difficulties to participate or join the group and the activities proposed. The perception of susceptibility of breast cancer was demonstrated when women reported believing that the cancer could not be avoided, regardless of social class, race or education. They attributed their occurrence to the repression of feelings and lack of preventive health behavior. The perception of the seriousness breast cancer as a chronic condition proved by considering the tumor stigmatizing. The fear of death and the consequences of the treatments led to new arrangements to promote social and family. The stimuli for action in seeking the rehabilitation group were discomforted, physical limitations and emotional, as well as referrals and recommendations from health professionals and advice of family and social network members. Perceived benefits to participating in the group were improved with the physical ability to return to daily activities, free care and specialized; relationship with the multidisciplinary team; psychological support; opportunity to share experiences, answer questions and feel in the midst of "their peers". Perceived barriers: the days and times of visits limited, housework, restricted physical space; necessity to demand time to attend the activities. The individual perceptions surveyed about breast cancer were influenced by their beliefs about susceptibility and seriousness over their experiences with the illness and its treatments, which led them to a health behavior to participate in the rehabilitation group because saw in others one way to take care of themselves' health by identifying, to this, barriers to greater benefits.
\end{abstract}

Keywords: nursing, rehabilitation, breast cancer. 


\section{RESUMEN}

CAETANO, E. A. Participación de mastectomizadas en un grupo de rehabilitación: beneficios y barreras percibidos. 2012. 102 f. Disertación (Máster) - Escuela de Enfermería de Ribeirão Preto, Universidad de São Paulo, Ribeirão Preto, 2012.

Estudio de abordaje cualitativo, que tuvo como objetivo analizar la percepción de mujeres con cáncer de mama acerca de la seriedad de la enfermedad, de su susceptibilidad a ella y de los beneficios y barreras para la participación en grupos de rehabilitación. Realizado en el Núcleo de Enseñanza, Investigación y Extensión Mujer y Cáncer de Mama - MUCAMA, en Alfenas (Provincia de Minas Gerais, Brasil), se utilizó como referencial teórico la Plantilla de Creencias en Salud y los conceptos de la Teoría de Campo de Kurt Lewin. Participaron 08 mujeres operadas de cáncer de mama, que comparecían regularmente al servicio, como mínimo tres meses antes de la recolección, entre mayo y julio de 2011. Los datos fueron recolectados por medio de grupos focales y entrevistas, utilizando un guión semiestructurado, y fueron analizados por el Análisis de Contenido Temático. Emergieron de los relatos dos temas y las respectivas categorías: Mujeres portadoras de cáncer de mama: percepciones acerca de la susceptibilidad y seriedad de la enfermedad - creencias sobre la susceptibilidad al cáncer de mama; la visión de la seriedad del cáncer de mama; los estímulos para la acción: la búsqueda de apoyo en el grupo de rehabilitación - y Beneficios y barreras percibidas en la decisión sobre participar del grupo de rehabilitación - el retorno a las actividades cotidianas y la rehabilitación psicosocial; percepción de las dificultades para participar del grupo y/o adherir a las actividades propuestas. La percepción de la susceptibilidad al cáncer de mama fue demostrada cuando las mujeres refirieron creer que el cáncer no puede ser evitado, independientemente de clase social, raza o escolaridad. Atribuyeron su ocurrencia a la represión de sentimientos y a la falta de un comportamiento preventivo en salud. La percepción de la seriedad del cáncer de mama como una condición crónica se mostró al considerar la neoplasia estigmatizante. El miedo a la muerte y las consecuencias de los tratamientos las llevaron a promover nuevos arreglos sociales y familiares. Los estímulos para la acción en buscar el grupo de rehabilitación fueron la incomodidad y las limitaciones físicas y emocionales, así como direccionamientos y recomendaciones de los profesionales de salud y consejos de familiares y miembros de la red social. Los beneficios percibidos para participación en el grupo fueron la mejora física con la posibilidad de retorno a las actividades diarias; atención gratuita y especializada; vínculo con el equipo multidisciplinar; apoyo psicológico; oportunidad de compartir experiencias, sanar dudas y sentirse en medio de "sus iguales". Las barreras percibidas: días y horarios de atenciones limitadas; quehaceres domésticos; espacio físico restricto; necesidad de demandar tiempo y disposición para la adhesión a las actividades. Las percepciones individuales de las entrevistadas acerca del cáncer de mama fueron influenciadas por sus creencias sobre susceptibilidad y seriedad a lo largo de sus experiencias con la enfermedad y sus tratamientos, lo que las llevó a un comportamiento en salud de participar del grupo de rehabilitación porque depositan en el mismo un medio para cuidar de su salud, identificando, para eso, mayores beneficios que barreras.

Palabras clave: Enfermería. Rehabilitación. Cáncer de mama. 


\section{SUMÁRIO}

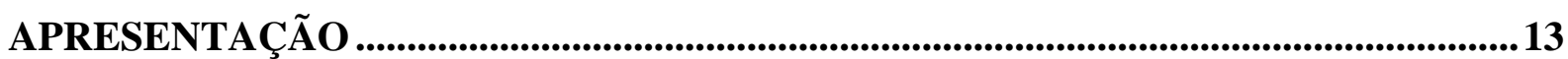

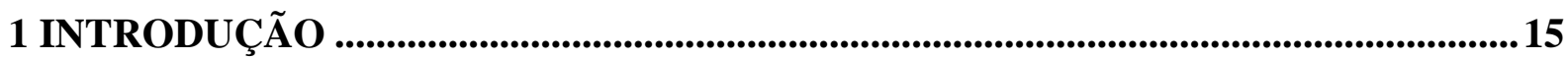

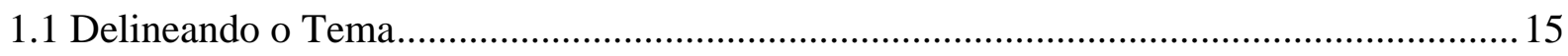



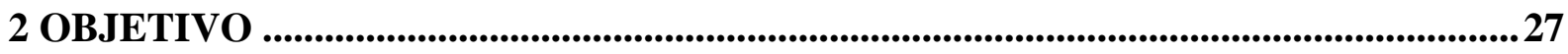

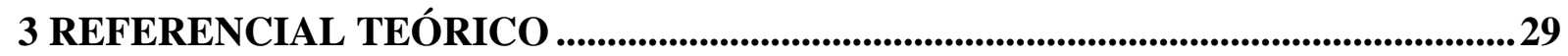

4 PERCURSO METODOLÓGICO ………………..............................................................36

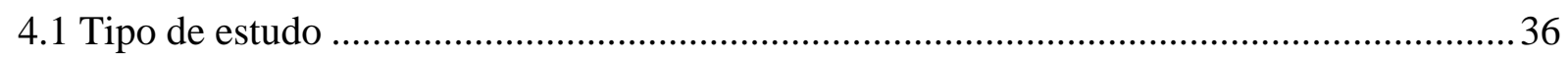

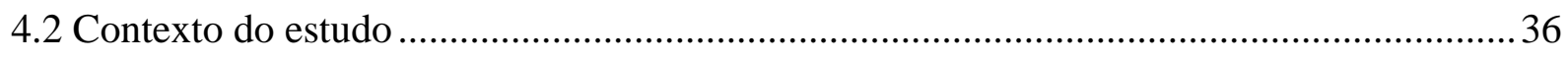

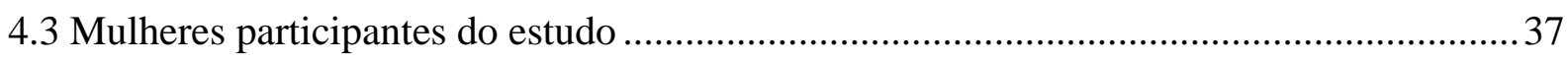

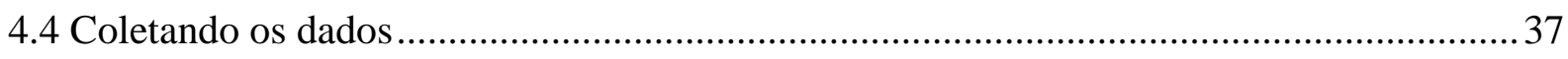

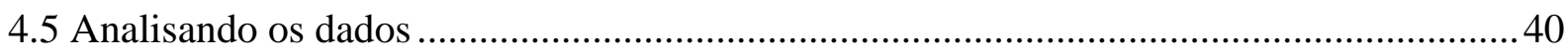

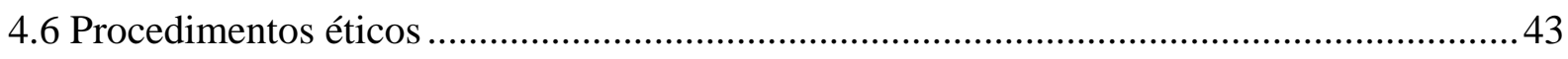

5 APRESENTANDO E DISCUTINDO OS RESULTADOS ...................................................45

5.1 Breve descrição das mulheres participantes do estudo.........................................................

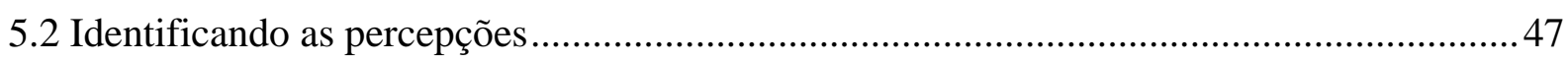

5.2.1 Mulheres portadoras de câncer de mama: percepções acerca da suscetibilidade e seriedade da doença .............................................................................................................4

5.2.1.1 Crenças sobre a suscetibilidade ao câncer de mama ........................................................ 48

5.2.1.2 A visão da seriedade do câncer de mama ........................................................................ 53

5.2.1.3 Os estímulos para a ação: a busca de apoio no grupo de reabilitação .............................63

5.2.2 Benefícios e barreiras percebidos na decisão sobre participar do grupo de

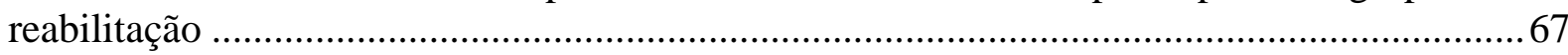

5.2.2.1 O retorno às atividades cotidianas e a reabilitação psicossocial ....................................67

5.2.2.2 Percepção das dificuldades para participar do grupo e/ou aderir às atividades

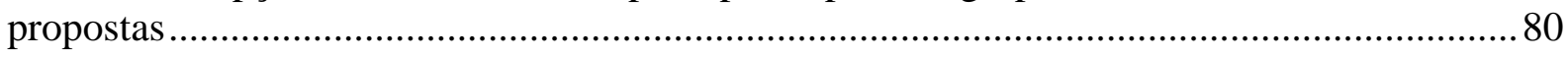

6 SÍNTESE DOS RESULTADOS DO ESTUDO E CONSIDERAÇÕES FINAIS ...........85

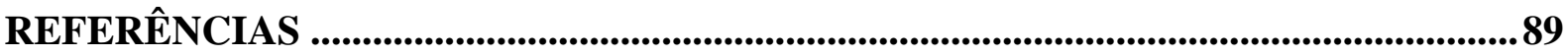

ANEXOS E APÊNDICES.........................................................................................99 
Apresentação 


\section{APRESENTAÇÃO}

Ingressei no curso de graduação em Enfermagem, pela Universidade Federal de Alfenas - MG, no ano de 2005. No ano seguinte, foi criado um projeto de extensão universitária voltado para a reabilitação global de mulheres mastectomizadas, hoje denominado Núcleo de Ensino, Pesquisa e Extensão Mulher e Câncer de Mama - MUCAMA.

Interessei-me pelas atividades desenvolvidas pelo projeto e entendi que essa seria uma oportunidade de grande aprendizado em minha formação profissional e em uma área pela qual eu tinha interesse em me aperfeiçoar.

Minha inserção no MUCAMA, desde sua criação em 2006, proporcionou-me a chance de atender mulheres com câncer de mama, em vários estágios da doença, e participar das etapas da reabilitação de mastectomizadas, tanto físico-funcional, quanto psicossocial. Além disso, pude desenvolver um trabalho de iniciação científica, em que pesquisei as reações e os modos de enfrentamento das mulheres ao receber o diagnóstico de câncer de mama. Os resultados de tal trabalho apontaram que uma das estratégias de enfrentamento da neoplasia mamária, para as mulheres, era a participação em grupos de reabilitação. Esses resultados instigaram-me a continuar investigando como um núcleo de reabilitação interfere na vida das mulheres mastectomizadas que o frequentam.

O MUCAMA propiciou-me uma aproximação com a realidade dessas mulheres e permitiu uma maior comunicação com essa clientela. Despertou-me atenção a confiança que elas depositavam no trabalho do núcleo, o valor que davam aos profissionais que as atendiam e algumas mudanças positivas no decorrer do processo de reabilitação do câncer e de seus tratamentos.

Ao participar de eventos relacionados à temática do câncer em mulheres, em especial a I Jornada de Oncologia, “Múltiplas abordagens assistenciais”, em 2006, e II Jornada de Câncer de Mama, em 2007, ambas promovidas pela Liga de Prevenção e Combate ao Câncer e pelo Núcleo de Ensino, Pesquisa e Assistência de Mastectomizadas - REMA da Escola de Enfermagem de Ribeirão Preto da Universidade de São Paulo - EERP/USP, busquei conhecer o trabalho de reabilitação de mulheres mastectomizadas em um grupo maior, já muito bem estruturado e com resultados promissores para as vidas das pacientes. Daí o interesse em cursar a pós-graduação strictu sensu na EERP/USP.

Após concluir a graduação, ingressei no mestrado, e me propus a realizar este estudo, cujos resultados acredito que poderão oferecer subsídios para a melhora da assistência a mulheres mastectomizadas, além de difundir o conhecimento e fornecer dados para novas produções científicas. 
Introdução 


\section{INTRODUÇÃO}

\subsection{Delineando o Tema}

O termo câncer, ou neoplasia, é utilizado para mais de cem doenças, que se caracterizam pelo crescimento desordenado de células, as quais invadem tecidos e órgãos, e que, quando se espalham, produzem metástases em várias partes do corpo. Multiplicando-se rapidamente, essas células tendem a ser muito agressivas e incontroláveis, determinando a origem de tumores malignos (OPAS, 2003).

A capacidade de invadir os tecidos vizinhos e de formar as metástases é responsável por levar a óbito dois em cada três pacientes com o diagnóstico de câncer (OTAKE; CHAMMAS; ZATZ, 2006). O poder de causar tantas mortes tornou essa doença muito temida pela população e é cada vez mais um problema relevante de saúde. Estima-se que a incidência de câncer aumentará de 10 milhões em 2000 para 15 milhões em 2020 (OPAS, 2003).

Os tumores mais incidentes na população brasileira, de acordo com as estimativas do Instituto Nacional de Câncer (INCA) para 2012, serão os de pele não melanoma (134 mil); próstata para os homens (60 mil); mama para as mulheres (53 mil); seguidos de cólon e reto (30 mil) e pulmão (27 mil) (BRASIL, 2012).

Em 2012, são estimados para o Brasil 52.680 casos novos de neoplasia mamária, com um risco de 52 casos a cada 100 mil mulheres. Sem considerar os tumores de pele não melanoma, esse tipo de câncer é o mais frequente nas mulheres das regiões Sudeste (69/100 mil); Sul (65/100 mil); Centro-Oeste (48/100 mil) e Nordeste (32/100 mil). Na região Norte, é o segundo tumor mais incidente (19/100 mil) (BRASIL, 2012).

Os cânceres apresentam diferentes modos de ocorrência que variam em função da causa, dos órgãos atingidos e dos tipos de tratamento requeridos. A neoplasia maligna da mama é um tipo de câncer que acomete as estruturas mamárias e pode também vir a comprometer a rede linfática proximal e desenvolver metástases à distância. Os sintomas do câncer de mama palpável são o nódulo ou tumor no seio, acompanhado ou não de dor mamária, podendo surgir ainda alterações na pele que recobre a mama, como abaulamentos ou retrações, bem como nódulos palpáveis na axila (BRASIL, 2011a).

Está bem estabelecido que fatores de risco relacionados à vida reprodutiva da mulher, tais como: menarca precoce; idade da primeira gestação a termo acima dos 30 anos; 
anticoncepcionais orais; menopausa tardia e terapia de reposição hormonal estão envolvidas no desenvolvimento do câncer de mama. Além desses, a idade continua sendo um dos mais importantes fatores de risco. As taxas de incidência aumentam rapidamente até os 50 anos, e posteriormente, ocorre de forma mais lenta, o que tem sido atribuído à menopausa (BRASIL, 2011b).

No entanto, nos dias atuais, verifica-se um aumento da incidência de câncer de mama em mulheres abaixo dos 40 anos, fato que pode ter relação com as mudanças no estilo de vida por elas adotadas, fazendo com que se exponham cada vez mais a poluentes, a ingestão de produtos enlatados, a alimentos gordurosos e a frituras (BRASIL, 2012; FERNANDES et al., 2005).

Além disso, a exposição à radiação ionizante, mesmo em baixas doses, particularmente durante a puberdade; a ingestão regular de bebida alcoólica, ainda que em quantidade moderada (30g/dia); a obesidade, principalmente quando o aumento de peso se dá após a menopausa e o sedentarismo aumentam o risco de se desenvolver câncer de mama. A prática de atividade física e o aleitamento materno exclusivo são considerados fatores protetores (BRASIL, 2009).

História familiar, principalmente em parentes de primeiro grau (mãe, irmã, filha) antes dos 50 anos é um importante fator de risco para o câncer de mama e pode indicar predisposição genética associada à presença de mutações em determinados genes. Entretanto, o câncer de mama de caráter hereditário corresponde a cerca de 5-10\% do total de casos (BRASIL, 2011b).

A ocorrência de neoplasia da mama encontra-se relacionada ao processo de urbanização da sociedade, evidenciando maior risco de adoecimento entre mulheres com elevado status socioeconômico, ao contrário do que se observa para o câncer do colo do útero. A prevenção primária desse tipo de câncer ainda não é totalmente possível em razão da variação dos fatores de risco e das características genéticas que estão envolvidas em sua etiologia (BRASIL, 2012).

Em relação ao diagnóstico, as formas mais eficazes para detecção precoce desse tipo de câncer são o exame clínico da mama e a mamografia, que somados à ultrassonografia, geralmente fornecem dados suficientes para o estadiamento clínico do tumor e para a opção entre os tratamentos (BRASIL, 2004).

Como modalidades de tratamento, podem ser utilizadas quatro terapias, em associação ou isoladamente, a saber: cirurgia, quimioterapia, radioterapia e hormonioterapia. A indicação 
de diferentes tipos de cirurgia depende do estadiamento clínico e do tipo histológico do tumor (BRASIL, 2011b).

A mastectomia é uma cirurgia mutiladora, que visa a remover todo o tumor visível. Dependendo da extensão da área acometida e do tipo histológico da massa tumoral, a cirurgia para sua remoção pode ser radical ou conservadora (SMELTZER; BARE, 2005)

A mastectomia parcial, ou conservadora, consiste na ressecção de um segmento da mama, com retirada dos gânglios axilares. É utilizada para tumores menores de três centímetros de diâmetro e realizada com margem de segurança de um centímetro do tecido mamário sem alterações (VERONESI, 2002).

Outra modalidade de cirurgia, a mastectomia radical, promove a remoção completa de todo o tecido mamário do lado afetado, incluindo a pele e o complexo aréolo-papilar. Existe, ainda, a mastectomia radical modificada, que consiste na retirada da glândula mamária e na remoção dos linfonodos axilares, com preservação de um ou ambos os músculos peitorais. No caso de haver a preservação do músculo peitoral maior, é denominada de mastectomia radical modificada Patey, e, quando os dois músculos peitorais são preservados, é chamada mastectomia radical modificada Madden (GUIRRO, 2002).

A quimioterapia, também utilizada para combater o câncer de mama, é um tratamento sistêmico com drogas antineoplásicas, a fim de eliminar células cancerosas e prevenir metástases. E ainda há a radioterapia, tratamento loco-regional que promove a irradiação de ondas de energia radioativas com o intuito de destruir as células tumorais, e a hormonioterapia, que consiste no uso de hormônios que inibem o crescimento de tumores hormôniodependentes (BRASIL, 2004).

O câncer de mama e seus tratamentos trazem para as mulheres acometidas problemas físicos e psicológicos. A mastectomia acarreta a elas mudanças em sua autoimagem, no relacionamento com o próprio corpo e afeta sua sexualidade (AMBRÓSIO, 2010; CAETANO; GRADIM; SANTOS, 2009; FABBRO; MONTRONE; SANTOS, 2008).

Acrescenta-se, ainda, o fato de que, no mundo ocidental, a mama é vista como um órgão representativo da feminilidade, de cunho erótico e de prazer sexual, além de ser responsável pelo aleitamento, pois faz à maternidade (DUARTE; ANDRADE, 2003; SILVA, 2008a).

Além da preocupação com a amputação do seio ou de parte dele, a mulher se depara com a possibilidade de vir a ter outras sequelas físicas que podem comprometer seus afazeres. Após o procedimento cirúrgico, algumas delas apresentam diminuição dos movimentos do braço (MELCHIOR, 2007) e enfrentam a ameaça do linfedema, que pode ocorrer logo após o 
procedimento cirúrgico, como pode demorar anos até o seu aparecimento (PANOBIANCO et al., 2008). Outras complicações ainda podem se apresentar, como deiscência, seroma, aderências, fibroses, celulite, problemas com o dreno aspirativo (PANOBIANCO; MAMEDE, 2002).

No que diz respeito à quimioterapia, apesar de sua comprovada eficácia, pode provocar eventos adversos, tais como: queda de cabelos, enfraquecimento de unhas, irritação e/ou sangramento gengival, anorexia, irritabilidade, desânimo, náusea, vômitos, fadiga, depressão, ansiedade, entre outros (BRASIL, 2008).

A queda dos cabelos é apontada em vários estudos como uma das consequências do tratamento para neoplasia da mama que mais causa sentimentos negativos nas mulheres acometidas. O impacto causado pela alopecia se deve ao fato de ela ocorrer de forma súbita e por ser a calvície algo visível exteriormente, difícil de esconder, o que expõe a doença e altera a autoestima de seu portador. Exerce, dessa forma, grande influência no enfrentamento das pacientes de sua condição de portadora de câncer de mama, gerando angústias e despertando a curiosidade de outras pessoas (AMBRÓSIO, 2010; CAETANO; GRADIM; SANTOS, 2009; FABBRO; MONTRONE; SANTOS, 2008).

A radioterapia é utilizada com o objetivo de destruir as células remanescentes após a cirurgia ou de reduzir o tamanho do tumor antes do procedimento cirúrgico (BRASIL, 2004). Passou a ser utilizada principalmente após a década de 1980, como coadjuvante no tratamento do câncer mamário, também induzindo alguns efeitos indesejáveis, destacando-se as lesões de pele, com formação de eritema na região irradiada. Além disso, pode causar anemia, alterações de paladar, mal-estar geral, fadiga e sonolência (SALVAJOLI; SILVA, 2008).

Ainda em relação aos tratamentos para o câncer de mama, o uso da hormonioterapia é questionável devido à produção de efeitos não desejáveis como menopausa precoce, osteoporose, disfunções sexuais e ressecamento vaginal. Porém, em tumores estrógenodependentes, permite significativa redução da mortalidade (FOLGUEIRA; BRENTANI, 2003; GRADIM, 2005).

Para Bittencourt e Cadete (2002), o diagnóstico de câncer de mama e as diferentes modalidades de tratamento interrompem os hábitos de vida da mulher e desencadeiam uma grave crise no seu equilíbrio biopsicossocial, provocando alterações em suas relações sociais e familiares, quase sempre provenientes de sentimentos de impotência e de frustração diante de um evento ameaçador que escapa ao seu controle.

No âmbito social, o câncer está relacionado à crença de que seu portador está condenado a morrer. Esse estigma é histórico devido às poucas chances de cura de que um 
paciente oncológico dispunha tempos atrás, com técnicas cirúrgicas mutiladoras e ausência de tratamentos adjuvantes eficazes (TAVARES; TRAD, 2005; TRINCAUS; CORREA, 2007). Porém, com o avanço das tecnologias médicas, tais pacientes têm maiores chances de reabilitação e de retomada de suas vidas cotidianas.

O estigma do câncer de mama leva a paciente a conviver com o preconceito e com sentimentos negativos nutridos por ela mesma. Desse modo, ela tem de elaborar novos conceitos de vida ao enfrentar sentimentos de impotência diante do sofrimento e da insegurança de cura que a doença transmite (CAETANO; GRADIM; SANTOS, 2009). Além disso, estudos evidenciam a permanência dos sentimentos de ameaça à integridade física e emocional da mulher, mesmo entre as sobreviventes de longo tempo (AMBRÓSIO, 2010; SILVA; SANTOS, 2008). Esse fato se deve ao medo da recorrência da doença, presente em muitas mulheres, quando são submetidas aos exames periódicos para controle do câncer (SILVA; SANTOS, 2008; VARELA et al., 2007).

Devido a todas essas alterações nas vidas das mulheres e de seus familiares, fica evidente a necessidade de uma assistência integral às portadoras de câncer de mama. Para Almeida et al. (2001), essa assistência deve acontecer desde o diagnóstico e o tratamento, mas se estender também a todo o processo de reabilitação após o câncer

Nesse sentido, dados do Instituto Nacional de Câncer - INCA (BRASIL, 2004) apontam que importantes avanços na abordagem do câncer de mama aconteceram nos últimos anos, principalmente no que diz respeito a cirurgias menos mutiladoras, assim como a busca da individualização do tratamento, e que uma melhor prestação de serviços em oncologia contribuiu substancialmente para aumentar as taxas de sobrevida de pessoas acometidas por essas patologias. Cho, Yoo e Kim (2006) e Almeida (2006) acrescentam que, aliado a esses avanços, um suporte para a assistência integral a portadoras de câncer de mama tem sido implementado em centros de reabilitação.

Etimologicamente, a palavra “reabilitação” refere que o prefixo latino $R E$ evoca um movimento para trás e/ou também, traduz a ideia de repetição, mudança de estado e algumas vezes, realce. Já "habilitação", é o ato ou efeito de habilitar-se por meio de um conjunto de conhecimentos, aptidões, ou seja, é capacidade. Quando juntamos a palavra “reabilitação”, esta impõe um sentido de readquirir crédito, estima ou bom conceito diante da sociedade (PITA, 1996).

O surgimento da reabilitação se deu especificamente para tratar danos físicos causados por doenças ou acidentes. Com o crescente avanço no conhecimento na área da saúde, os profissionais passaram a incorporar o conceito com uma maior amplitude, pois apenas a 
reparação de uma deficiência física não permite a maximização das potencialidades dos pacientes para manterem ou para readquirirem seus papéis sociais. Assim, o conceito de reabilitação tem sido ampliado para incluir aspectos psicossociais, vocacionais e econômicos, podendo abranger não somente o paciente, mas a família e a comunidade (JUÁREZ, 2003).

Para a Organização Mundial da Saúde (WHO, 1980), a reabilitação é um processo interdisciplinar, integrado, coordenado, de abordagem individualizada, voltada para a exploração do potencial global do indivíduo, considerando-se as dimensões física, psicológica, social e ocupacional, respeitando as suas limitações, para que a pessoa possa atingir maior grau de independência pessoal e, consequentemente, de reintegração social.

Atualmente, na oncologia, a reabilitação é considerada parte do tratamento e do cuidado do indivíduo acometido pela doença, devendo estar disponível em todas as fases, desde o diagnóstico e tratamentos, além de incorporar os sobreviventes e sua condição advinda do aumento de sua expectativa de vida. As mulheres com câncer de mama, por exemplo, estão vivendo mais de cinco anos após o término da terapêutica. Além disso, a população está envelhecendo e a prevalência de câncer está aumentando (DeLISA, 2001; GERBER, 2001).

A reabilitação no câncer deve ser entendida, portanto, como um processo educativo, dinâmico, criativo e progressivo, voltado para a identificação e para a exploração do potencial da portadora da doença, buscando sua integração ou reintegração no seu meio social, e dandolhe a oportunidade de continuar ativa e produtiva (ALMEIDA, 2006).

O conceito de reabilitação no câncer envolve, ainda, ajudar uma pessoa portadora dessa neoplasia a obter o máximo de rendimento positivo, seja ele físico, psicológico, social e até mesmo profissional, para que ela possa retomar o que parou a partir do diagnóstico (DeLISA, 2001).

Assim, o objetivo final da reabilitação no câncer, e aqui, mais especificamente, no câncer de mama, deve ser o alcance de um status funcional adequado dentro dos limites da doença, de seu tratamento e das escolhas da mulher, uma vez que fatores como possível redução da expectativa de vida, dor e co-morbidades associadas torna singular e desafiador o processo de reabilitação (ALMEIDA, 2006; DeLISA, 2001).

Faz-se necessária, portanto, a criação de espaços que ofereçam cuidados integrais às mulheres, que lhes forneçam desde informações sobre o curso da doença e suas possíveis complicações, passando por cuidados com a ferida operatória ou com o membro homolateral à cirurgia, por informações sobre reconstrução mamária até orientações sobre o autocuidado. Esses espaços podem contribuir para que a mulher elabore sua visão de um corpo modificado 
e trabalhe a aceitação de sua nova imagem e de questões ligadas à sexualidade (CHO; YOO; KIM, 2006).

As mulheres acometidas pelo câncer de mama também devem ter a oportunidade de falar sobre suas angústias, suas dificuldades, dúvidas e experiências com a doença e seus tratamentos, bem como sobre as complicações. É importante que tenham contato com pessoas que têm problemas semelhantes aos seus. Fabbro, Montrone e Santos (2008) comentam que isso colabora para o desenvolvimento de um clima de muito valor terapêutico, em que são quebradas barreiras criadas por sentimentos de solidão e de isolamento.

No que se refere ao apoio psicossocial, já é bem documentado na literatura que a participação em grupos auxilia as mulheres em relação aos sentimentos de isolamento e de solidão, ajudando também no desenvolvimento de novas maneiras de lidar com o câncer de mama, ampliando a rede de suporte social e reduzindo o impacto emocional causado pela doença, pelo tratamento e pelas complicações, aumentado assim sua autoestima (GOMES et al., 2003).

O grupo proporciona, ainda, a volta das mulheres à plenitude de suas atividades profissionais, domésticas e afetivas por intermédio de estímulos para a sua reabilitação total (OLIVEIRA; SOUZA; FERNANDES, 2008).

Percebemos a importância do espaço educacional que o grupo proporciona, pois, além de as mulheres obterem informações sobre sua doença e sobre o curso do tratamento, podem, por meio do aprendizado obtido no grupo, ajudar outras mulheres que recebem o diagnóstico de neoplasia de mama (PINHEIRO et al., 2008).

O suporte de um grupo torna-se, portanto, indispensável para a reabilitação de mulheres que tiveram diagnóstico de câncer de mama, colaborando também para o crescimento e para o desenvolvimento individual e coletivo.

Em corroboração a essas afirmações, outros estudos sugerem que uma proporção substancial de mulheres com câncer beneficia-se participando de grupos de reabilitação, e comentam que a oportunidade de conhecer outras pacientes na mesma situação e de dividir suas próprias experiências foi avaliada como um componente muito útil e muito apreciado pelas participantes de suas pesquisas (CHO; YOO; KIM, 2006; EDELMAN; CRAIG; KIDMAN, 2000; PETERSSON et al., 2000).

Nesse sentido, os artigos que abordam as atividades grupais não adotam uma conceituação única para grupos de reabilitação, que alguns consideram como um espaço em que são desenvolvidos exercícios de relaxamento e sessões de informação; outros, como um espaço educativo e interativo, mais voltado para grupo de apoio por causa da presença do 
profissional. Outros têm a característica puramente de autoajuda, em que as pessoas que compartilham de uma experiência comum dividem seus anseios, saberes e práticas. No entanto, um enfoque dado hoje aos grupos de reabilitação é aquele que os mostra como um espaço em que o indivíduo pode receber suporte profissional e multidisciplinar adequado, com o objetivo final do alcance máximo de sua funcionalidade física e psicossocial, numa perspectiva integral (EDELMAN; CRAIG; KIDMAN, 2000; PETERSSON et al., 2000, ZIMERMAN, 2000).

É a esse tipo de grupo que nos referiremos neste estudo.

A utilização de grupos de reabilitação no câncer de mama tem aumentado nos últimos anos para atender ao crescente número de casos novos e de sobreviventes da doença ao longo dos anos. Estudo desenvolvido em um núcleo de reabilitação de mastectomizadas mostrou que as intervenções físicas e psicossociais parecem obter resultados satisfatórios, uma vez que o retorno das mulheres é livre e, mesmo assim, o comparecimento das mesmas é crescente e assíduo (ALMEIDA, 2006).

Outros estudos acrescentam que a assistência prestada em grupos de reabilitação permite, ainda, que aspectos não rotineiramente observados pelo médico, e muitas vezes não expostos pela paciente, possam ser trabalhados com maior ênfase, apresentando melhores resultados (CHO; YOO; KIM, 2006) e que a participação no serviço permite que as mulheres operadas por câncer de mama focalizem a responsabilidade por sua saúde e por um estilo de vida mais saudável e de maior qualidade (SILVA, 2008b).

Estudo bibliográfico realizado por Pereira et al. (2006) apresentou os aspectos básicos de um grupo de reabilitação, que foi apontado como uma das principais estratégias de enfrentamento do câncer de mama para as mulheres portadoras. De acordo com os autores, nesses grupos, cada encontro tem um momento de educação em saúde, no qual são abordados assuntos que oferecem informações clínicas sobre o câncer de mama e sobre a mastectomia. É nesse espaço que também se reforça a importância da palpação das mamas para o conhecimento do corpo e para a detecção de possíveis alterações.

Em outro momento, é trabalhada a reabilitação física da mulher mastectomizada, realizando-se exercícios para o membro homolateral à mama afetada. Durante o encontro também são promovidas trocas de experiências entre as participantes, o que facilita o enfrentamento da situação de saúde-doença de cada uma e, por fim, são realizados exercícios de relaxamento e lazer, contribuindo para a reabilitação psicossocial (PEREIRA et al., 2006).

Fernandes et al. (2005) estudaram um grupo no qual eram desenvolvidas atividades de reabilitação física e psicossocial. As mulheres com câncer de mama, participantes de sua 
pesquisa, consideraram o grupo como um espaço de real significado para suas vidas e, assim, concluíram as autoras que a assistência à mulher mastectomizada não deve focalizar apenas a doença e a reabilitação física; deve abranger um contexto amplo, que envolva os aspectos culturais, educacionais, econômicos e sociais de cada uma das mulheres envolvidas no trabalho do grupo.

Para Fabbro, Montrone e Santos (2008), a realização de grupos em ambientes acolhedores, nos quais é possibilitada a troca de saberes e experiências, pode se constituir em um espaço para as mulheres com câncer de mama compartilharem suas preocupações, propiciando uma maior tranquilidade consigo mesmas e uma maior disponibilidade para aceitação do tratamento.

De acordo com Ambrósio (2010) e Caetano, Gradim e Santos (2009), o grupo, assim como a família, os amigos e a religiosidade são sistemas de apoio que atuam de forma positiva no desempenho de novos papéis da mulher mastectomizada. Desse modo, vários autores trazem as atividades grupais, realizadas por uma equipe multiprofissional, como principal estratégia de cuidado para a reabilitação de mulheres mastectomizadas. Com elas, busca-se promover a autoestima da mulher, contribuindo para a melhoria de sua qualidade de vida (PEREIRA et al., 2006; PINHEIRO et al., 2008; RODRIGUES; SILVA; FERNANDES, 2003).

O câncer de mama desestrutura a mulher no sentido de trazer para a sua convivência a incerteza da vida, demonstrando a suscetibilidade à doença. A possibilidade de recorrência e a incerteza do sucesso do tratamento também denotam uma característica severa à patologia, fazendo com que as pacientes sofram profundas modificações em suas vidas e necessitem de suporte para se readaptarem à sua nova condição (VIEIRA; LOPES; SHIMO, 2007).

Nesse sentido, estudo realizado por Pinheiro et al. (2008) demonstra que os grupos têm emergido como recurso para o enfrentamento da situação e da superação do sofrimento oriundo do diagnóstico e do tratamento do carcinoma mamário.

Existe, portanto, uma série de fatores que podem levar mulheres com diagnóstico de câncer de mama a participar de um grupo de reabilitação, que são citados na literatura e muitas vezes apontados pelas próprias pacientes, destacando-se, dentre eles, a prática da atividade física; a presença de profissionais especializados; o apoio psicossocial, reforçando o suporte dos familiares, bem como o incremento das orientações por meio de material ilustrativo (FRANCO, 2011; GUTIÉRREZ et al., 2007; PRADO et al., 2004).

A participação no grupo auxilia, desse modo, no que diz respeito à atitude na prática de atividade física, essencial à reabilitação motora, colaborando também para a compreensão 
das modificações físicas secundárias ao tratamento do câncer e das novas perspectivas do tratamento da doença, além de auxiliar na readaptação psicossocial (GOMES et al., 2003).

No entanto, barreiras para a participação e para a adesão às atividades empreendidas no grupo de reabilitação global de pacientes com câncer de mama também podem ser verificadas. Estudo desenvolvido por Prado et al. (2004) revelou que uma das principais barreiras apontadas pelas mulheres participantes de seu estudo foi a falta de força de vontade para aderir às orientações.

Sant’anna et al. (2010), ao realizarem uma revisão de literatura acerca da adesão à prática de exercícios para reabilitação funcional de mulheres com câncer de mama, encontraram que ela é influenciada pela falta de tempo, pelos efeitos indesejáveis dos tratamentos antineoplásicos e pelas responsabilidades familiares, que constituem as principais barreiras ao seguimento de um programa de reabilitação física. Esses resultados coincidem com os de outras pesquisas como as de Rogers et al. e de Daley et al., em dois estudos realizados no ano de 2007.

Franco (2011) apontou, ainda, que as mulheres com câncer de mama por ela pesquisadas e que frequentavam um núcleo de reabilitação de mastectomizadas sentiam necessidade de um espaço maior para o desenvolvimento das atividades, bem como maior número de dias e horários de atendimento.

Nesse estudo, pressupomos que, ao mesmo tempo em que as mulheres podem encontrar barreiras para a participação no grupo e para a adesão às atividades propostas, elas acreditam nos benefícios que podem advir do grupo para sua reabilitação, pois percebem a seriedade da doença e sua suscetibilidade a ela.

Dessa forma, compreender a percepção de mulheres com câncer de mama acerca dos benefícios e barreiras para a participação em grupos de reabilitação tornou-se o foco principal deste trabalho. Para tal propósito, consideramos que se faz necessário explorar as crenças das participantes sobre sua suscetibilidade e sobre a seriedade do câncer de mama, uma vez que elas podem guiar a tomada de ação dessas mulheres para com sua saúde e sua reabilitação.

Acreditamos que a responsabilidade que as mulheres assumem quanto à busca de boas condições de saúde e a importância que atribuem a comportamentos saudáveis, bem como a maneira como vivenciam a situação de apresentar uma doença rodeada de estigma, suas expectativas quanto à resolução do problema, suas experiências anteriores, o conhecimento que possuem relativo ao problema e suas crenças podem influenciar em suas condutas em relação à sua saúde. 
Como destacam Caetano, Gradim e Santos (2009), o desafio dos enfermeiros é prestar acolhimento e atendimento humanizado às mulheres portadoras de neoplasia mamária, para que elas tenham uma atitude positiva perante o adoecimento. Fabbro, Montrone e Santos (2008) corroboram a importância do acesso a serviços de saúde que busquem efetivamente oferecer atenção integral à mulher e que propiciem momentos de educação em saúde, de reabilitação física e psicossocial nos quais as clientes e profissionais de saúde possam compartilhar conhecimentos, experiências e vivências em relação à saúde e à doença, contribuindo, desse modo, para a melhoria da qualidade de vida.

\subsection{Justificativa}

Esperamos que os resultados deste estudo ofereçam subsídios para aprimorar a assistência prestada às mulheres mastectomizadas que frequentam serviços de reabilitação e estimulem a participação nesses serviços, assim como a adesão das mulheres às atividades e orientações, visando a melhorar sua qualidade de vida e seu bem-estar; e que o conhecimento adquirido sirva de estímulo para novas investigações científicas e para a criação de novos espaços especializados em reabilitação. 
Objetivo 


\section{OBJETIVO}

Analisar a percepção de mulheres com câncer de mama acerca da seriedade da doença, de sua suscetibilidade a ela e dos benefícios e barreiras para a participação em grupos de reabilitação. 


\section{REFERENCIAL TEÓRICO}

Utilizamos como referencial teórico o Modelo de Crenças em Saúde (MCS), que procura esclarecer o comportamento humano quanto ao processo saúde-doença, enfatizando-o como modelo explicativo dos processos cognitivos que culminam com a prática de comportamentos saudáveis (COUTO, 1998).

O MCS surgiu na tentativa de elucidar por que as pessoas não se previnem de maneira satisfatória contra certas doenças ou não utilizam programas de "screening" para detecção precoce de doenças assintomáticas (LESCURA; MAMEDE, 1990; DELA COLETA, 2004).

Elaborado inicialmente por Becker, Drachman, Kirscht e Rosenstock e publicado em 1966, o MCS buscava explicar o comportamento humano no processo saúde. Posteriormente, foi aplicado a comportamentos relacionados à manutenção da saúde em geral, incluindo o atendimento correto às orientações dos profissionais de saúde, como no caso deste estudo, às recomendações dos profissionais do grupo de reabilitação (LESCURA; MAMEDE, 1990).

Apenas uma década depois de ser publicado, autores como Janz e Becker (1984) já consideravam o MCS como principal modelo para elucidar e predizer a aceitação das pessoas de recomendações sobre cuidados com sua saúde.

De acordo com seus idealizadores, para que o indivíduo manifeste comportamentos preventivos em relação à sua saúde, é preciso que ele considere e acredite que uma determinada doença apresente chances reais para prejudicar sua saúde, estando ele suscetível a ela, e que sua possível ocorrência teria, pelo menos, moderada seriedade em algum componente de sua vida (LESCURA; MAMEDE, 1990).

Assim como o indivíduo necessita de acreditar em sua suscetibilidade à determinada doença, ele precisa crer também que as mudanças em seu comportamento relacionadas à sua saúde ocasionarão benefícios, ou seja, que tais transformações são capazes de reduzir sua suscetibilidade àquela doença, ou se a patologia já se instalou, reduzindo a sua seriedade (ROSENSTOCK, 1990).

O MCS revela que existem barreiras psicológicas significativas, capazes de impedir que o indivíduo tome ações relacionadas à prevenção de doenças (LESCURA; MAMEDE, 1990).

Ao tratar das barreiras percebidas pelo indivíduo, o MCS esclarece que existe uma relação custo-benefício na avaliação dos aspectos negativos da ação, ou seja, um indivíduo pode crer que uma determinada ação será efetiva em reduzir a ameaça da doença, porém considerar que aquela ação não é conveniente ou mesmo possível, demandando gastos, tempo, 
ou seja, considerada desagradável ou potencialmente dolorosa, etc. Esses aspectos negativos da saúde servem como dificuldades à adoção de comportamentos saudáveis e ocasionam conflitos (ROSENSTOCK, 1990).

Os elaboradores do Modelo de Crenças em Saúde observaram que, quanto maiores os benefícios percebidos à adoção de uma determinada ação de saúde e quanto menores as barreiras percebidas, maiores são as chances de adesão pelo indivíduo (LESCURA; MAMEDE, 1990).

A crença de que toda conduta é motivada é a premissa básica do Modelo de Crenças em Saúde. A motivação é a condição para a ação e os motivos agem de forma seletiva para determinar as percepções do ambiente pelo indivíduo, ou seja, uma pessoa que analisa a possibilidade de ter um dado problema de saúde e que considera, sobre todas as coisas, que o curso da ação a ser tomado poderá reduzir a ameaça, terá motivos para mudar seu comportamento em saúde (LESCURA; MAMEDE, 1990).

O quadro abaixo revela que outras variáveis podem também afetar a percepção individual, influenciando diretamente a ação final. São os fatores biográficos, estruturais e psicossociais (DELA COLETA, 2004).

Quadro 1: O Modelo de Crenças em Saúde como determinante do comportamento preventivo em saúde (LESCURA; MAMEDE, 1990):

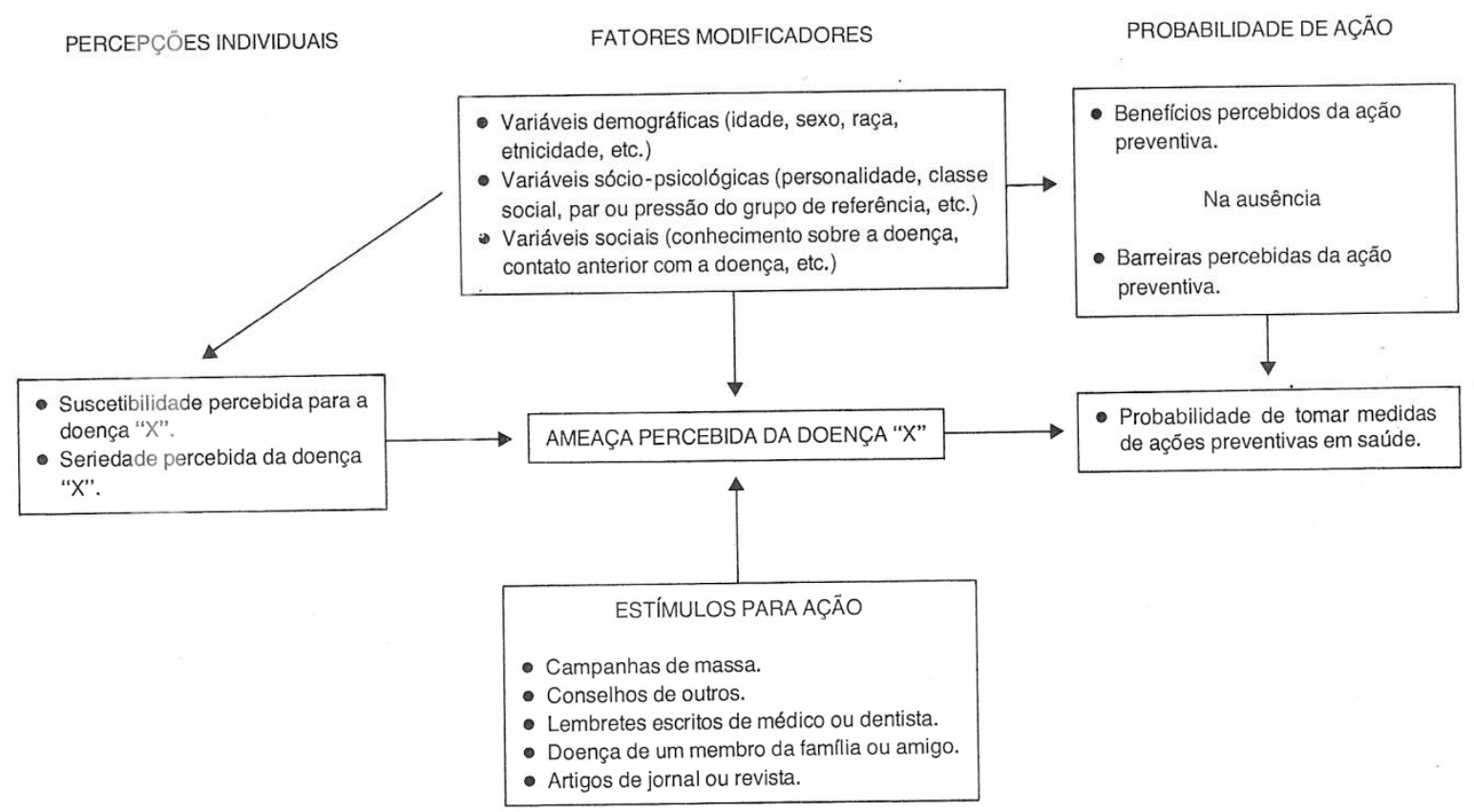


O modelo lida basicamente com quatro variáveis: suscetibilidade, seriedade, benefícios e barreiras percebidas (LESCURA; MAMEDE, 1990).

A suscetibilidade percebida diz respeito à percepção individual do risco desse indivíduo de contrair determinada doença, que varia conforme a aceitação, também pessoal, da possibilidade de contraí-la. Encontramos indivíduos que negam qualquer probabilidade de adquirir determinada condição de saúde; já outros indivíduos, podem admitir alguma probabilidade de contrair uma doença, ou outros que expressam sentimentos de estar em perigo real de adquirir a condição patológica (ROSENSTOCK, 1990).

A seriedade percebida refere-se à gravidade da doença que pode ser julgada de acordo com o grau de perturbação emocional criado no indivíduo ao pensar na doença ou também pelos tipos de consequências que a doença pode acarretar na vida dos que a contraem, como sofrer preconceitos, por exemplo (ROSENSTOCK, 1990).

Desse modo, quando falamos em "seriedade” da doença, consideramos um campo muito mais abrangente do que uma simples seriedade clínica ou médica desta, envolvendo relações familiares, posição financeira e ocupação, conforme explicam Lescura e Mamede (1990).

O comportamento que determina ações relacionadas com a saúde dependerá do grau de ameaça percebida pelo indivíduo que se traduz pela sua realidade subjetiva (LESCURA; MAMEDE, 1990).

O MCS foi influenciado pelas teorias de Kurt Lewin, cujos fundamentos se pautam na compreensão de que o mundo do percebedor é que gera suas ações e condutas e não o ambiente físico que o determina, embora este tenha significativo papel, mas sim e tão somente pela maneira pela qual ele é representado na mente do indivíduo. O foco da aplicação do modelo é ligar os atuais estados subjetivos do indivíduo com o atual comportamento de saúde (LESCURA; MAMEDE, 1990).

A Teoria de Campo de Lewin focaliza sua atenção mais no fenômeno psicológico de motivação do que no de percepção. Para Lewin (1965), a determinação da posição da pessoa dentro do espaço de vida é a primeira exigência para compreender o comportamento.

Uma das afirmações básicas da Teoria de Campo psicológico pode ser formulada da seguinte maneira: qualquer comportamento, ou qualquer outra mudança no campo psicológico, depende somente do campo psicológico daquele momento. Porém, uma situação num determinado momento na realidade não se refere a um momento sem extensão no tempo, mas a um determinado período de tempo, tendo um caráter dinâmico (LESCURA; MAMEDE, 1990). 
Dessa maneira, o efeito do passado sobre o comportamento só pode ser indireto; o campo psicológico passado é uma das “origens” do campo presente e este, por sua vez, afeta o comportamento. Relacionar comportamento com o passado, portanto, pressupõe conhecer suficientemente como o fato passado mudou o campo naquele momento, e se, no meio tempo, outros fatos modificaram ou não novamente o campo. A Teoria de Campo pressupõe que o comportamento não depende nem do passado nem do futuro, mas do campo presente. Inclui, portanto, o passado psicológico, o presente psicológico e o futuro psicológico, que constituem uma das dimensões do espaço de vida existindo num determinado momento (LESCURA; MAMEDE, 1990).

Para Lewin (1965), apenas os fatos presentes podem ser responsáveis pelo comportamento e sempre insistiu em seus trabalhos na necessidade de se levar em conta os fatos tais como eles existem psicologicamente e independentemente de sua realidade externa à pessoa. O passado e o futuro, quando considerados no presente, passam a ser presentes psicologicamente.

A Teoria de Campo dá ênfase ao fato de que qualquer acontecimento é resultante de um considerável número de fatores. O reconhecimento da necessidade de fatores interdependentes é um passo em direção da Teoria de Campo. Desse modo, um elemento não pode ser analisado isoladamente dentro da situação, sendo que sua importância não pode ser julgada sem se considerar a situação como um todo. Depois dessa primeira caracterização, os vários aspectos e partes da situação passam por uma análise cada vez mais específica (LESCURA; MAMEDE, 1990).

Assim, o nível de realidade do passado, presente e futuro psicológicos corresponde a uma situação como realmente existiu, existe e existirá de acordo com as crenças do indivíduo. Portanto, a vulnerabilidade das pessoas às ameaças à sua saúde faz com que racionalmente os indivíduos emitam comportamentos saudáveis, sendo esta a suposição dos elaboradores do MCS. A essas percepções, os indivíduos acabam por atribuir um valor que os leva a acreditar ou não na eficácia das ações tendentes à melhoria da sua saúde. Desse modo, a partir dessas crenças, é possível prenunciar diferentes comportamentos relacionados com a saúde, quer no nível da prevenção da doença, quer no nível da promoção da saúde ou da reabilitação (COUTO, 1998).

Somente a partir do momento em que o indivíduo for capaz de reconhecer benefícios que o levem a superar as barreiras, alcançará grandes probabilidades de êxito em sua decisão de cometer uma determinada ação, que se traduz numa modificação do seu comportamento (COUTO, 1998). 
As percepções de suscetibilidade, seriedade, benefícios e barreiras podem ser influenciadas por fatores modificadores constituídos, fundamentalmente, por três tipos de variáveis, enumeradas por Couto (1998):

- Variáveis demográficas: incluem sexo, raça, etnia;

- Variáveis psicossociais: personalidade, classe social, grupos de pressão;

- Variáveis estruturais: conhecimento que o indivíduo tem sobre o processo patológico e contatos anteriores com a doença.

Tais variáveis podem modificar a percepção dos benefícios e barreiras às ações preventivas, influenciando indiretamente o comportamento do indivíduo em relação à saúde.

Mesmo se o indivíduo reconhecer os benefícios, as barreiras, a sua suscetibilidade e gravidade da doença, se ele conferir pouca importância à sua saúde, o grau de adesão a uma ação proposta se torna muito baixo, logo a “disposição para a ação” proposta acaba por ser pequena ou até mesmo nula, não se materializando (COUTO, 1998).

Conforme referem Maiman e Becker (1974) esse modelo apresenta caminhos para compreender como um indivíduo poderia diminuir a suscetibilidade e a seriedade a uma dada condição de saúde e fazer uma estimativa individual de probabilidade de sucesso, baseada na percepção dos benefícios serem maiores que as barreiras. Como variável motivacional, destaca-se o estímulo para a saúde e, como conseqüência, a disposição para agir. Assinalam ainda a suscetibilidade versus a severidade (benefícios x barreiras) como as proposições básicas do modelo.

Quanto aos conceitos contidos no MCS, Rosenstock (1974), define aqueles relacionados aos diferentes comportamentos de saúde, destacando os que seguem:

- Comportamento na saúde: definido como qualquer atividade empreendida por uma pessoa que acredita estar saudável, com o propósito de prevenir doenças ou detectá-las em um estágio assintomático (LESCURA; MAMEDE, 1990);

- Comportamento frente aos sintomas: definido como qualquer atividade empreendida por uma pessoa que se sente doente, com o propósito de definir seu estado de saúde e de descobrir o remédio adequado (LESCURA; MAMEDE, 1990);

- Comportamento da doença: refere-se à atividade empreendida por aqueles que se considerem doentes, com o propósito de curar-se (LESCURA; MAMEDE, 1990).

Portanto, o referencial aqui adotado auxiliará na compreensão sobre as expectativas que as mulheres têm a respeito dos grupos de reabilitação e identificação de marcadores de importância na promoção da saúde de mulheres mastectomizadas durante o seu processo de reabilitação. 
O MCS vem sendo aperfeiçoado desde sua elaboração e também vem ocorrendo uma crescente ampliação do mesmo em diversos estudos, de diferentes áreas, principalmente na enfermagem, na psicologia e na medicina, relacionadas a moléstias e condutas em saúde (DELA COLETA, 2004). A partir das formulações do modelo, pesquisadores têm utilizado o MCS com adaptações de acordo com os objetivos propostos.

Consideramos que a fundamentação teórica escolhida está adequada a este estudo, uma vez que o MCS representa uma alternativa importante para os estudiosos que visam pesquisar ou intervir em saúde e avaliar a influência dos fatores subjetivos sobre o comportamento dos indivíduos. 
Percurso Metodológico 


\section{PERCURSO METODOLÓGICO}

\subsection{Tipo de estudo}

Trata-se de uma pesquisa de abordagem qualitativa. O estudo qualitativo aborda um universo de significados, motivos, aspirações, crenças, valores e atitudes, permitindo uma visão mais ampla das relações, dos processos e dos fenômenos relacionados às diversas áreas da vida de um ser humano (MINAYO, 2007).

\subsection{Contexto do estudo}

A pesquisa foi realizada com mulheres integrantes do projeto de extensão Núcleo de Ensino, Extensão e Pesquisa Mulher e Câncer de Mama - MUCAMA, que funciona nas dependências da Escola de Enfermagem da Universidade Federal de Alfenas - UNIFAL MG, desde 2006. Estão inscritas no serviço 116 mulheres, que são atendidas por uma enfermeira docente, uma fisioterapeuta, um odontólogo e por oito acadêmicos de enfermagem e quatro, de fisioterapia.

As mulheres chegam para participar do serviço de reabilitação por meio de encaminhamentos de médicos da região ou da indicação da Associação Vida Viva de Alfenas.

As atividades do projeto visam orientar sobre as fases do tratamento cirúrgico e adjuvante e sobre o autocuidado com o braço homolateral à cirurgia; estimular a realização de exercícios que melhoram a movimentação do braço e a postura; oferecer tratamento para pacientes que apresentam linfedema; orientar e ensinar a automassagem para drenagem linfática.

Os encontros ocorrem todas as quintas-feiras, no turno da tarde, das 17 às 19 horas, sendo que na primeira vez em que a mulher comparece ao serviço, é realizado um levantamento da história da moléstia atual e de co-morbidades associadas, com preenchimento de uma ficha que será o seu prontuário, o qual possui dados de identificação, de hábitos de vida, da cirurgia, do tratamento adjuvante e é anotada a perimetria dos braços.

No início do atendimento, das 17 às 18 horas, são realizados os exercícios físicos de forma coletiva para as mulheres com menor comprometimento funcional, e individuais para 
as iniciantes ou com complicações como o linfedema. São oferecidos e orientados por um fisioterapeuta ou enfermeira treinada. Havendo necessidade, das 18 às $18 \mathrm{~h} 30$ minutos, é feita a drenagem linfática e o enfaixamento do braço das mulheres que deles necessitam, depois de avaliadas pelas profissionais.

Após a realização dos exercícios, no horário de $18 \mathrm{~h} 30$ minutos às 19 horas, é oferecida uma atividade denominada "roda da dúvida”, espaço em que as mulheres podem questionar sobre o seu tratamento e que visa esclarecer dúvidas. Os profissionais também proporcionam a chamada “conversa terapêutica” no intuito de estimular a união e a amizade entre essas clientes e as profissionais que as assistem. $\mathrm{O}$ assunto a ser debatido é exposto pela cliente.

O MUCAMA visa, ainda, promover a realização de trabalhos científicos que possam contribuir para o progresso da ciência, além de se constituir em campo de estágio para alunos do curso de graduação em Enfermagem da UNIFAL-MG.

\subsection{Mulheres participantes do estudo}

Participaram do estudo mulheres com diagnóstico de câncer de mama que frequentavam o MUCAMA, regularmente, há pelo menos três meses do início da coleta, e que apresentaram disponibilidade e aceitação para participar voluntariamente do estudo.

Os demais critérios para inclusão dessas mulheres na pesquisa foram: ter realizado a cirurgia de mastectomia; participar efetivamente do grupo de reabilitação, de debates e de dinâmicas, regularmente, e ter boa orientação no tempo, no espaço e como pessoa.

Critérios de exclusão: dificuldades de entendimento das perguntas a elas dirigidas nas entrevistas que impedissem a participação do estudo.

\subsection{Coletando os dados}

A coleta aconteceu no período de maio a julho de 2011, e foi finalizada no momento em que os dados empíricos possibilitaram a compreensão do objeto de estudo, contando com oito mulheres participantes do MUCAMA. 
Foram esclarecidos os objetivos da pesquisa, o anonimato e o direito de desistência em qualquer etapa da mesma, sem prejuízo às participantes e, após, solicitada assinatura do Termo de Consentimento Livre e Esclarecido (TCLE).

Primeiramente, foram separados prontuários de atendimento das mulheres que contemplaram os critérios de inclusão na amostra. O convite para participar da pesquisa foi feito pela pesquisadora, que já participa da equipe multiprofissional do MUCAMA, nos dias e horários de atendimento ou em outros dias e horários, por telefone.

Os dados pessoais, sociodemográficos, sobre tratamento e evolução no MUCAMA foram retirados do prontuário e mesclados com as informações obtidas com grupos focais, realizados no decorrer da coleta dos dados. Foram anotados em formulário específico, do qual constavam dados gerais sobre os tratamentos das participantes (dados de identificação como: iniciais do nome, data de nascimento, ocupação, escolaridade, estado civil, tipo e data da cirurgia, outros tratamentos e data de primeiro comparecimento ao MUCAMA ) e dados sobre as crenças e percepções das mulheres, tendo as categorias sido pré-definidas pautando-se nas dimensões do MCS: suscetibilidade e seriedade ao câncer de mama; benefícios e barreiras para participação no grupo de reabilitação (Apêndice A).

Antes da aplicação do instrumento de coleta de dados, este foi submetido à avaliação de juízes, ou seja, profissionais de saúde que prestam assistência às mulheres que frequentam o grupo de reabilitação e as sugestões de mudanças foram realizadas.

Anteriormente à coleta de dados, foi também efetuado um teste-piloto, com a realização de um grupo focal, para adaptação do instrumento de coleta, procedendo aos ajustes necessários, visando à completa compreensão das perguntas pelas participantes.

Na segunda etapa, teve início a investigação com grupos focais, que é um método de pesquisa qualitativa utilizado para identificar informações de um subgrupo de uma população específica. A discussão é planejada para obter informações num ambiente permissivo onde as participantes podem expor livremente suas ideias, percepções, comentários, além de se influenciarem mutuamente pelos diálogos que surgem durante a discussão (MORGAN, 1997).

Os grupos focais constituem um tipo de entrevista em grupo que valoriza a comunicação entre os participantes da pesquisa a fim de gerar dados. Os grupos focais verdadeiros são explicitamente projetados para valorizar a integração grupal para fornecer tipos distintos de dados (POPE; MAYS, 2009). Isso significa que, em vez de o pesquisador pedir a cada pessoa para responder a uma pergunta por vez, as pessoas são estimuladas a falar umas com as outras, a perguntar, a trocar histórias e a comentar sobre as experiências e os pontos de vista umas das outras. 
As atividades que envolvem a aplicação da técnica de grupo focal requerem envolvimento em ações diversas, tais como: organização do espaço físico, gravação das atividades e posterior transcrição do áudio obtido. Gatti (2005) recomenda que, mesmo obtendo-se gravação em áudio, sejam feitas anotações escritas, essenciais para auxiliar as análises. Tais anotações mostram aspectos importantes, momentos associados a falas significativas e, em outras palavras, questões cuja importância podem ser percebidas no registro geral. Assim, utilizamos um caderno para anotações das principais impressões advindas do debate.

Kind (2004) refere que, para a realização do grupo focal, são necessários um moderador e um observador, enquanto Levorlino e Pelicioni (2001) acrescentam a esses a figura do relator. Atendendo às recomendações da literatura, foram convidadas para as funções de observadora e relatora, respectivamente, duas graduandas em Enfermagem da mesma Instituição, participantes do MUCAMA, enquanto a pesquisadora atuou como moderadora.

Foram realizados três grupos focais, nas dependências da Escola de Enfermagem da Universidade Federal de Alfenas - UNIFAL/MG, com duração média de uma hora e meia cada, sempre com as mesmas integrantes, conforme orientações de Gatti (2005).

Para a conclusão, ao final do debate, foi solicitado às mulheres participantes fazerem comentários sobre o que acharam da atividade; informou-se a divulgação dos resultados do estudo a ser realizada mediante entrega de exemplares da dissertação para o MUCAMA e foi feito agradecimento pela participação de todas.

Para complementar os dados advindos da realização dos grupos focais, a pesquisadora procedeu à terceira etapa da pesquisa, em que agendou com as participantes entrevistas semiestruturadas, em domicílio, utilizando o mesmo formulário. Essa técnica de coleta de dados combina perguntas abertas e fechadas, em que o entrevistador tem a oportunidade de discorrer sobre o tema em questão sem se prender à indagação formulada (MINAYO, 2007).

Assim, percebeu-se uma complementação entre as diferentes técnicas de coletas de dados, que proporcionou, como comentam Barros, Lehfeld (2005), um diálogo entre as várias técnicas qualitativas, utilizadas e combinadas, visando a produzir um conhecimento mais profundo da realidade.

O conteúdo resultante da coleta de dados foi transcrito na íntegra, pela própria pesquisadora, e decodificado depois de leituras exaustivas do material, emergindo as questões relevantes para a apresentação e análise dos resultados. 


\subsection{Analisando os dados}

Os dados resultantes da aplicação dos grupos focais e das entrevistas foram analisados pela técnica de Análise de Conteúdo (BARDIN, 2004) que, como técnica de tratamento de dados, é derivada das metodologias quantitativas e busca sua lógica na interpretação do material de caráter qualitativo. Nesse tipo de análise, busca-se desconstruir a fala e buscar o “que está por trás dos conteúdos manifestos” (MINAYO 2007, p. 74).

Minayo (2007) acrescenta que a análise de conteúdo, em termos gerais, relaciona estruturas semânticas (significantes) com estruturas sociológicas (significados) dos enunciados.

Entre as várias técnicas para análise de conteúdo, encontram-se a análise de expressão, a análise de relações, a análise de enunciação e a análise temática. Esta última foi utilizada no presente estudo, e consiste em “descobrir os núcleos de sentido que compõem a comunicação, cuja presença ou frequência signifiquem alguma coisa para o objetivo analítico visado”. Além disso, é adequada à investigação qualitativa do material sobre saúde (MINAYO, 2007, p. 210).

Delimitam-se, primeiramente, as unidades de codificação ou as de registro, cuja ocorrência é anotada de acordo com as categorias levantadas e podem ser: a palavra; a frase; o tema, sendo este último o adotado no presente estudo. Para Bardin (2004, p. 105), tema é “a unidade de significação que se liberta naturalmente do texto analisado segundo os critérios relativos à teoria que serve como guia à leitura”; no caso do presente estudo, as dimensões de suscetibilidade, seriedade, benefícios e barreiras percebidos do MCS. A seguir, conforme orienta Minayo (2007), as unidades de registro foram agrupadas por convergência de significados, classificadas e agregadas em categorias teóricas ou empíricas comandadas pelas especificações dos temas.

Em termos da organização da análise, no presente contexto de estudo, adotamos as seguintes etapas, em conformidade com Bardin (2004):

1) A pré-análise;

2) A exploração do material;

3) O tratamento dos resultados, a inferência e a interpretação. 


\section{A pré-análise}

Em primeira instância, é realizada a organização propriamente dita dos materiais. A préanálise corresponde, portanto, a um período de intuições, de buscas iniciais, mas tem por objetivo tornar operacionais e sistematizar as ideias dos primeiros contatos com os materiais, de maneira a conduzir a um esquema preciso do desenvolvimento das operações sucessivas e com vistas à elaboração de um plano de análise, ou seja, objetiva a organização (BARDIN, 2004). Essa etapa pode ser decomposta em tarefas:

a) A leitura flutuante: a primeira atividade da pré-análise consiste em estabelecer contato com os documentos a analisar e em conhecer o tema, deixando-se invadir por impressões, representações, conhecimentos, expectativas e orientações das mensagens neles contidas;

b) A escolha dos documentos - Constituição do Corpus: Trata-se da organização dos documentos selecionados para serem submetidos aos procedimentos analíticos, ou seja, a constituição de um corpus, o qual, neste estudo, se constitui de conteúdo expresso pelas falas das mulheres com câncer de mama, durantes os encontros. Para Bardin (2004), sua constituição implica escolhas, seleções e regras:

Regra da exaustividade: uma vez definido o campo do corpus (entrevistas de um inquérito, respostas a um questionário, etc), é preciso considerar todos os elementos desse corpus. Em outras palavras, não se pode deixar de fora qualquer um dos elementos por esta ou por aquela razão (dificuldade de acesso, impressão de não-interesse), que não possa ser justificável no plano do rigor. Complementando, é preciso direcionar todos os esforços para buscar informações complementares com o objetivo de configurar e esclarecer o contexto e as condições sociais, políticas e culturais contidas nas mensagens emitidas. Esse fato justifica a adoção neste trabalho da busca de dados em prontuários das características sociodemográficas das participantes do mesmo e da utilização do referencial teórico que trabalha com a causalidade do comportamento em saúde na visão dos sujeitos, no caso, das mulheres com câncer de mama.

Regra da representatividade: conforme Bardin (2004), a análise pode efetuar-se numa amostra desde que o material a isso se preste. A amostragem diz-se rigorosa, se a amostra for uma parte representativa do universo inicial. Nesse caso, os resultados obtidos poderão ser generalizados ao todo. 
Regra da homogeneidade: os documentos retidos devem ser homogêneos, quer dizer, devem obedecer a critérios precisos de escolha e não apresentarem demasiada singularidade que exceda os critérios e os objetivos definidos. Procuramos realizar a coleta de dados por meio de instrumento norteador mediante a utilização de abordagens semelhantes nos vários encontros, em situações igualmente semelhantes; todos com a participação dos mesmos sujeitos.

c) Formulação de hipóteses e objetivos: em relação ao material qualitativo, devem ser estabelecidos pressupostos iniciais para a formulação do objetivo, que é a finalidade geral a que se propõe o estudo. No caso, partimos do pressuposto de que as mulheres buscam o grupo porque veem nele um meio para cuidar de sua saúde e que, ao mesmo tempo em que elas podem encontrar barreiras para a participação no grupo e para a adesão às atividades propostas, acreditam nos benefícios que podem advir do grupo para sua reabilitação, pois percebem a seriedade da doença e sua suscetibilidade a ela. O objetivo final do estudo foi, portanto, o de analisar a percepção de mulheres com câncer de mama acerca da seriedade da doença, de sua suscetibilidade a ela e dos benefícios e barreiras para a participação em grupos de reabilitação.

\section{A exploração do material}

A exploração do material consiste, essencialmente, na operação de codificação, por meio da qual se realiza a transformação dos dados brutos, visando a alcançar o núcleo de compreensão do texto. Primeiramente, trabalha-se com recortes do texto em unidades de registro que podem ser uma palavra, uma frase, um tema, um personagem, um acontecimento tal como foi estabelecido na pré-análise (BARDIN, 2004).

Após, escolhem-se as regras de contagem ou de convergência dos dados, uma vez que, tradicionalmente, elas se constroem em marcadores que permitem de alguma forma a representatividade das dimensões do MCS. A partir dessa fase, realizam-se a classificação e a agregação dos dados, escolhendo as categorias teóricas ou empíricas que comandarão a especificação dos temas (BARDIN, 2004). Desse modo, a exploração do material não é mais do que a administração sistemática das decisões tomadas.

Ocorre a operação classificatória, buscando-se alcançar o núcleo de compreensão do texto. A classificação em categorias deve obedecer às seguintes regras de acordo com Bardin (2004): homogeneidade: os documentos devem ser homogêneos; exaustão: esgotar a totalidade do texto; exclusivas: um mesmo elemento do conteúdo não pode ser classificado, 
aleatoriamente, em duas categorias diferentes; objetivas: codificadores diferentes devem chegar a resultados iguais; adequadas e pertinentes: isto é, adaptadas ao conteúdo, ao objetivo e ao quadro teórico definido.

\section{0 tratamento dos resultados obtidos e a interpretação}

Os resultados brutos são submetidos a operações que permitem colocar em relevo as informações obtidas. Prosseguindo, o pesquisador realiza interpretações previstas no seu quadro teórico ou abre outras pistas em torno de dimensões teóricas sugeridas pela leitura do material (BARDIN, 2004).

Procuramos, por meio das falas das mulheres, organizadas em categorias, discutir e interpretar quais seriam as percepções das entrevistadas acerca da suscetibilidade e da seriedade do câncer de mama e a ameaça percebida da doença; quais foram os fatores modificadores dessas percepções e os estímulos para a ação e a probabilidade de ação que vislumbraram em tomar medidas preventivas no cuidado com sua saúde em participar do grupo de reabilitação, buscando, assim, alcançar o objetivo do estudo.

Desse modo, emergiram dois temas dos relatos e as respectivas categorias responsáveis pela especificação dos mesmos: mulheres portadoras de câncer de mama: percepções acerca da suscetibilidade e seriedade da doença - crenças sobre a suscetibilidade ao câncer de mama; a visão da seriedade do câncer de mama; os estímulos para a ação: a busca de apoio no grupo de reabilitação - e Benefícios e barreiras percebidos na decisão sobre participar do grupo de reabilitação - o retorno às atividades cotidianas e a reabilitação psicossocial; percepção das dificuldades para participar do grupo e/ou aderir às atividades propostas.

\subsection{Procedimentos éticos}

Foram respeitados os procedimentos éticos para pesquisas com seres humanos, contidos na resolução 196/96, do Conselho Nacional de Saúde (BRASIL, 1996). O desenvolvimento do projeto de pesquisa foi aprovado pelo Comitê de Ética da Escola de Enfermagem de Ribeirão Preto - EERP/USP, sob o parecer 1200/2010 (Anexo A), e pela coordenação do MUCAMA para a sua realização naquele local (Anexo B). Todas as participantes do estudo assinaram o Termo de Consentimento Livre e Esclarecido (TCLE) (Apêndice B). 
Apresentando e Discutindo os Resultados 


\section{APRESENTANDO E DISCUTINDO OS RESULTADOS}

\subsection{Breve descrição das mulheres participantes do estudo}

\section{Entrevistada 1}

Mulher de 67 anos, casada, mora com o esposo e tem uma filha que reside em outro Estado. É católica, do lar, residente e domiciliada em Alfenas - MG, possui ensino fundamental completo. Participa do serviço (MUCAMA) há 05 anos, desde a fundação. A principal atividade no grupo é a drenagem linfática, uma vez que possui linfedema. Realizou mastectomia total com reconstrução mamária. É alegre, bem disposta e possui boa interação com a equipe multiprofissional.

\section{Entrevistada 2}

Mulher de 60 anos, divorciada, morava com a mãe, mas, após o falecimento dela reside sozinha, não possui filhos. É católica praticante, aposentada, residente em Alfenas - MG, possui ensino superior completo. Participa do grupo desde a fundação, tendo como atividade principal os exercícios em grupo. Submeteu-se à quadrantectomia, com tratamento complementar com radioterapia e quimioterapia. É assídua no grupo, bem disposta e esclarecida.

\section{Entrevistada 3}

Mulher de 50 anos, casada, mora com o marido e não possui filhos. É católica, do lar, residente em Alfenas - MG, possui ensino médio completo. É membro do grupo há 03 anos, participando efetivamente dos exercícios em grupo. Submeteu-se à quadrantectomia, com tratamento adjuvante com sessões de quimioterapia. É sempre lembrada pelo seu bom humor e pela visão otimista da vida. Sempre procura ajudar as iniciantes e animar as atividades do grupo.

\section{Entrevistada 4}

Mulher de 67 anos, viúva, reside com as netas e possui quatro filhos. Católica praticante, aposentada, mora em Alfenas - MG, possui ensino fundamental completo. Foi casada por duas vezes, sendo que ambos os maridos eram etilistas crônicos, o que, segundo ela, colaborava para uma vida atribulada. Comparece ao grupo há, aproximadamente quatro anos, tendo sido encaminhada por uma amiga. Pratica exercícios individuais e em grupo. 
Realizou mastectomia tipo Patey e tratamento complementar com quimioterapia e hormonioterapia. É calma e procura acatar as orientações fornecidas no grupo.

\section{Entrevistada 5}

Mulher de 63 anos, casada, reside com o marido em Alfenas-MG. Teve cinco filhos, sendo uma falecida por câncer de mama. É católica, aposentada, possui ensino fundamental incompleto. Está no segundo casamento e trabalhava antes como faxineira. Relata que vivia uma vida atribulada com o primeiro marido, do qual é viúva, mas que com o atual tem um relacionamento amistoso. Comparece ao grupo desde sua criação, em 2006, tendo sido encaminhada pela Associação Vida Viva e por uma amiga. Realizou mastectomia total com radioterapia, quimioterapia e hormonioterapia. É receptiva, bem humorada e assídua no grupo.

\section{Entrevistada 6}

Mulher de 55 anos, casada, católica, residente em Alfenas - MG. Possui 05 filhos, sendo dois casados e três solteiros que moram com ela e o esposo. Cursou até o $4^{\circ}$ ano do ensino fundamental e trabalhava como auxiliar de laboratório, estando afastada por causa do adoecimento. Cuida dos pais idosos que moram no mesmo terreno. Frequenta o grupo há, aproximadamente, 06 meses. Realizou quadrantectomia e quimioterapia. É calma e relata receber apoio da família e de amigos para o enfrentamento da doença.

\section{Entrevistada 7}

Mulher de 54 anos, casada, do lar, católica, possui três filhos e cursou o ensino fundamental. Nascida em Alfenas - MG, retornou à cidade quando diagnosticada por câncer de mama. Realizou mastectomia total e se submeteu a sessões de radioterapia e de quimioterapia. Também é cardiopata já tendo sido submetida a duas cirurgias. Veio ao grupo encaminhada pela Associação Vida Viva e o frequenta desde sua criação.

\section{Entrevistada 8}

Mulher de 63 anos, divorciada, do lar, residente em Alfenas-MG, católica, tem 5 filhos. Possui o ensino médio. Conta que se separou do marido após uma traição e acredita que esse fator esteja relacionado à gênese do câncer de mama. Fez reposição hormonal dos 49 aos 52 anos. Comparece ao grupo há, aproximadamente 01 ano, tendo sido encaminhada por uma amiga que já frequentava o grupo. Realizou nodulectomia e, depois, quadrantectomia, com tratamento adjuvante de radioterapia e de quimioterapia. 


\subsection{Identificando as percepções}

A partir da transcrição das entrevistas e após a leitura exaustiva das falas, surgiram conteúdos referentes ao papel do grupo de reabilitação nas vidas das mulheres que o frequentam, sendo identificadas as percepções sobre seriedade da doença e sua suscetibilidade a ela, bem como sobre os benefícios e as barreiras para a participação no grupo e a adesão às atividades propostas. Durante o processo analítico das falas, à luz do Modelo de Crenças em Saúde, emanaram categorias dentro das dimensões do referencial teórico.

Quadro 2: Apresentação das categorias identificadas nas dimensões do MCS

\begin{tabular}{|c|c|}
\hline Temas & Categorias \\
\hline $\begin{array}{l}\text { 5.2.1 Mulheres portadoras } \\
\text { de câncer de mama: } \\
\text { percepções acerca da } \\
\text { suscetibilidade e seriedade } \\
\text { da doença }\end{array}$ & $\begin{array}{l}\text { 5.2.1.1 Crenças sobre a suscetibilidade ao câncer de } \\
\text { mama } \\
\text { 5.2.1.2 A visão da seriedade do câncer de mama } \\
\text { 5.2.1.3 Os estímulos para a ação: a busca de apoio no } \\
\text { grupo de reabilitação }\end{array}$ \\
\hline $\begin{array}{l}\text { 5.2.2 Benefícios e } \\
\text { barreiras percebidos na } \\
\text { decisão sobre participar do } \\
\text { grupo de reabilitação }\end{array}$ & $\begin{array}{l}\text { 5.2.2.1 O retorno às atividades cotidianas e a reabilitação } \\
\text { psicossocial } \\
\text { 5.2.2.2 Percepção das dificuldades para participar do } \\
\text { grupo e/ou aderir às atividades propostas }\end{array}$ \\
\hline
\end{tabular}

\subsubsection{Mulheres portadoras de câncer de mama: percepções acerca da suscetibilidade e seriedade da doença}

A suscetibilidade percebida refere-se à percepção subjetiva do indivíduo acerca dos riscos existentes ou de sua vulnerabilidade em apresentar um determinado problema de saúde. Nos casos de agravos já estabelecidos, inclui a aceitação do diagnóstico e a avaliação pessoal de sua re-suscetiblidade e da suscetibilidade para doenças em geral (ROSENSTOCK, 1990). A aceitação de ser suscetível é variável entre os indivíduos que podem negar qualquer 
possibilidade de contrair uma doença, admitir que exista possibilidade, porém pouca probabilidade de ocorrência, ou de percepção de um risco real de contraí-la (ROSENSTOCK, 1974).

Outra dimensão do MCS, abordada nesse tema, é a seriedade do câncer de mama que está relacionada ao estímulo emocional criado pelo pensamento acerca de um problema de saúde e às consequências que o indivíduo acredita que este poderia provocar em sua vida. Sentimentos relativos à seriedade de uma doença, ou sua recidiva, ou deixá-la sem tratamento levariam o indivíduo a avaliar as consequências clínicas e físicas resultantes das complicações, como dor, redução das funções físicas e mentais, temporária ou permanentemente, possíveis consequências sociais, como implicações no trabalho, na vida familiar e ou relações sociais, ou mesmo a morte (ROSENSTOCK, 1990).

Nessas dimensões, identificamos as categorias: crenças sobre a suscetibilidade ao câncer de mama; a visão da seriedade do câncer de mama; os estímulos para a ação: a busca de apoio no grupo de reabilitação.

\subsubsection{Crenças sobre a suscetibilidade ao câncer de mama}

Nesta categoria, independentemente das formas como se sentiam suscetíveis ou não ao câncer, os depoimentos das mulheres qualificam a doença como casual e democrática, uma vez que não pode ser evitada, e incide em qualquer que seja a classe social, a raça ou a escolaridade:

“O câncer é assim, ele não escolhe quem ele 'pega' independente se a pessoa é preta ou branca, rica ou pobre” E3

“Sabe, eu vejo que o câncer não dá só em pessoas simples como a gente, ele é ‘democrático', pode acontecer com qualquer um” E5

"No começo eu tive revolta, revolta comigo mesma, eu pensava assim, eu falava coisas que não tinha nada a ver, eu falava: poxa! por que comigo? Mas não é bem assim, ninguém tá livre, essa doença não escolhe pessoa, não diz: ah, eu vou escolher esse aqui porque esse aqui é pobre... não, não existe isso" E2

Na sociedade ocidental, as crenças historicamente construídas sobre o câncer são de uma doença que invade o corpo, incurável, misteriosa, que gera sofrimento e perdas. Embora 
os progressos dos meios diagnósticos e das terapêuticas tenham ampliado a sobrevivência dos pacientes, essa percepção persiste, contribuindo com reações de revolta e de resignação após o diagnóstico (BERGAMASCO; ÂNGELO, 2001).

Considerando que o câncer é uma das principais causas de morte no Brasil, não é difícil compreender a percepção negativa e o sentimento de medo que envolve os assuntos relacionados à patologia. A “doença maligna”, cujo nome na maioria das vezes não é sequer pronunciado, vem se tornando cada vez mais expressiva e, a cada ano, acomete um número maior de pessoas (BRASIL, 2012).

A suscetibilidade ao câncer de mama foi atribuída por algumas mulheres a variáveis sócio-psicológicas, como as características de personalidade e ou estados psicológicos, como repressão de sentimentos, conforme exposto nas falas a seguir:

\footnotetext{
"Ah, (acho que eu tive câncer porque...) eu sou assim muito quieta, não sou de ficar contando as coisas, sofro calada!” E6

"Tudo eu sofria ficava calada e não contava a minha família entendeu? Guardava tudo e um dia isso explode. Se você fica guardando, guardando, um dia adoece mesmo, é o que eu acho. (...) Minha doença foi toda isso. O desgosto da separação, muitas mágoas guardando, guardando, guardando acaba nisso” E2
}

Assim, ainda nos dias atuais, no imaginário popular, o surgimento do câncer de mama está relacionado com eventos emocionais negativos vivenciados ao longo da vida da mulher (TAVARES; TRAD, 2005). Parece que qualquer comportamento ou traço de personalidade avaliado como prejudicial para as participantes está associado à gênese do câncer. Dessa forma, são apontados não só traços depressivos e melancólicos da personalidade de quem adoece como também aqueles de ansiedade, como possíveis causas da doença:

\footnotetext{
"Eu sou assim, muito ansiosa, mas é que sempre tive que segurar as pontas lá em casa calada” E4

"Eu acho que você ficar ansiosa, só envolvida com problemas pode contribuir para você ter câncer” E5
}

Culturalmente, as mulheres são orientadas para suportar o sofrimento e dar prioridade às necessidades dos outros, sendo socializadas para reprimir e ocultar suas mágoas e dores (FERNANDES; MAMEDE, 2004). A maneira como as mulheres deste estudo viveram até o aparecimento do câncer evidencia um tipo de criação com muitas repressões, ainda muito presente em nossa sociedade, em que a mulher vive em função da família, responsabilizando- 
se por tudo o que, muitas vezes, faz com que deixem os cuidados com sua saúde para último plano:

"A minha vida sempre foi de muitas preocupações, cuidar dos filhos, do marido e da casa, nunca sobrava tempo pra mim” E5

"Eu fiquei muito tempo pensando só na minha família, por isso acabava me cuidando menos do que deveria” E8

Observamos, no entanto, que a ênfase dada até pouco tempo sobre a concepção de que determinados estados psicológicos e certas características de personalidade do doente eram importantes fatores predisponentes ao câncer, atualmente tem sido questionada, uma vez que se pode denotar uma forma punitiva ao processo saúde-doença, da mesma forma como se deu no passado a noção da doença como um castigo (AMBRÓSIO, 2010).

Estudo desenvolvido por Fernandes e Mamede (2004) revela que, para as mulheres participantes daquele estudo, a causa da doença sempre esteve relacionada a algum tipo de punição por um mau comportamento, comumente ligado à falta de cuidado com o corpo.

Na presente investigação, o discurso das participantes mostra que, para elas, a doença é um castigo pela conduta de negligência com a saúde. A falta de conhecimento adequado sobre a doença e sua prevenção, a falta de tempo ou ainda as dificuldades para conseguir marcar uma consulta (fator modificador) são citados como fatores que aumentaram a probabilidade de emissão de comportamentos não saudáveis do ponto de vista de prevenção e de detecção precoce da doença:

"A falta de conhecimento de a gente não saber como prevenir. Como eu não sabia da importância dos exames, eu não procurava o médico, também nunca tinha tempo" E6

“A gente não se cuidava, não é mesmo?! Eu mesma não sabia de quanto em quanto tempo tinha que fazer a mamografia” E4

"Eu não me tocava certinho, não tinha aquele zelo de estar sempre apalpando os meus seios, o dia que eu achei o caroço, ele já estava grandinho” E8

“A gente não ter assim um plano de saúde ou uma maior facilidade de conseguir uma consulta, também desmotivava muito, mas agora eu corro atrás e consigo tudo que preciso” E7

A realidade do câncer de mama traz à consciência das mulheres o quanto o cuidado consigo mesmas é colocado em segundo plano, revelando, portanto, que fatores modificadores como os socioculturais podem estar envolvidos nos processos de saúde e de 
doença. Para Almeida et al. (2001), diante da situação vivida, muitas mulheres passam a refletir acerca das ações tomadas com relação à sua saúde e percebem o descaso que tiveram com o próprio corpo.

Diante do exposto, é importante salientar que atualmente, devido às permanentes taxas altas de morbi-mortalidade para o câncer de mama, em nosso país, ele é considerado umas das prioridades da atenção à saúde (BRASIL, 2006), e esforços do governo têm sido empreendidos na tentativa de conscientizar a população feminina da importância dos programas de prevenção. Porém, parte significativa das mulheres ainda não obtém informações claras sobre as medidas preventivas que devem adotar em relação à neoplasia de mama, contribuindo para a demora na procura pelos serviços de saúde, conforme observamos pelas falas. E, ainda, outro fator que contribui para a detecção do câncer de mama em fases avançadas é a dificuldade e o limitado acesso da população a serviços de saúde.

As crenças sobre a importância da detecção precoce na visão das estudadas pode influenciar o modo como elas agem diante da doença:

“Antes eu era ignorante, pensava: quem procura demais, acha! Mas, hoje eu vejo que quando o câncer tem de aparecer, ele acontece de qualquer jeito, daí é melhor a gente se cuidar pra descobrir mais cedo, não é?!” E5

De acordo com o MCS, um indivíduo pode acreditar que uma dada ação seja efetiva em reduzir a ameaça à saúde, porém, ao mesmo tempo, considerar que há percalços para sua efetivação, ou seja, considerá-la inconveniente, onerosa, desconfortável, dolorosa ou geradora de ansiedade (ROSENSTOCK, 1990).

Outro determinante da ausência de comportamento preventivo em saúde, detectado nas falas das mulheres participantes de nosso estudo, remete-nos à identificação de hábitos culturais, historicamente construídos, como aqueles de que as mulheres devem ser recatadas, evitarem se tocar e se olhar no espelho, como uma forma de repressão de sua sexualidade. Dessa forma, nos seus discursos, identificaram-se, como comentam Talhaferro, Lemos e Oliveira (2007), características de uma educação de base familiar que as coíbia não somente de questões relacionadas à prática sexual, mas de todo o exercício da sexualidade, como a segurança, a exploração da autoimagem, do prazer, do desejo, da sensação de bem-estar consigo e com seu corpo:

"Eu acho que um dos motivos da gente demorar a perceber o caroço, porque o médico disse que ele já estava lá fazia tempo, era que eu não tinha costume de me tocar, sei lá a gente foi educada pra isso” E5 
"A gente é criada de uma forma muito tímida, por isso não tínhamos costume de ficar nos tocando” E8

Corroborando ainda com os achados do estudo de Fernandes e Mamede (2004), as mulheres deste estudo atribuíram a causalidade do câncer de mama à influência do meio cultural no qual foram criadas e estão inseridas.

Entendemos, portanto, que uma assistência adequada às mulheres com câncer de mama irá ocorrer num contexto em que as suas concepções e experiências em relação à sua doença sejam consideradas, discutidas e esclarecidas, e que o grupo de reabilitação se revela como um espaço em que elas podem ser estimuladas a falar sobre suas vivências e dúvidas a respeito da doença e de seus tratamentos, permitindo-lhes uma participação efetiva nesse processo.

As mulheres deste estudo mostraram, ainda, que suas crenças sobre a suscetibilidade ao câncer estavam relacionadas também a alguns marcadores comportamentais como: realização de terapia de reposição hormonal; uso de anticoncepcional oral; não amamentação; ingestão de alimentos ricos em gorduras; exposição à poluição; estilo de vida sedentária; ocorrência de eventos estressantes e grande número de preocupações:

"Dizem que quem tomou muita pílula para prevenir filhos tem mais chance de ter o câncer e eu tomei. A moça do postinho ainda me disse que, como eu amamentei pouco os meus filhos, isso foi ruim pra mim” E4

"O médico falou que eu tinha que fazer reposição hormonal, mas eu não quis, só que daí como eu tinha muita onda de calor acabei fazendo e não deu seis meses apareceu o câncer” E8

A percepção da suscetibilidade e da seriedade da doença como um mecanismo de forte componente cognitivo (LESCURA; MAMEDE, 1990) mostra-se mesmo que parcialmente, dependente do conhecimento que as mulheres adquiriram sobre o câncer de mama. Nesse sentido, o conteúdo das falas das estudadas revelou que a percepção delas sobre o grau de suscetibilidade a que estiveram expostas à aquisição da doença, bem como das suas consequências foram influenciados pelas suas crenças individuais acerca do câncer de mama e seus fatores de risco. De acordo com a abordagem de campo psicológico de Kurt Lewin, as estudadas representaram seus campos psicológicos naquele momento da entrevista como constituídos de fatos passados que, para elas, seguramente influíram na sua percepção sobre a suscetibilidade à doença, e, consequentemente, na protelação de tomada de ação em relação a comportamentos dirigidos à proteção da saúde. 
Tais achados reforçam a necessidade de os profissionais de saúde buscarem estratégias de implementação de orientações à população sobre os fatores de risco para o câncer de mama, fornecendo esclarecimentos consistentes e de fácil entendimento para as mulheres. Dentre os esclarecimentos, o INCA estabelece o aleitamento materno e a prática de atividade física, bem como a manutenção do peso corporal, como fatores protetores para a mulher em todo o curso de vida (BRASIL, 2009).

Portanto, o sinergismo do comportamento humano relacionado à saúde, como elucidado pela Teoria de Campo (LEWIN, 1965), se mostrou evidente nas falas das entrevistadas, uma vez que foi possível identificar que as percepções individuais no presente psicológico das mulheres sofreram influências de fatores modificadores de percepção da ameaça sobre a doença, e na determinação de comportamentos preventivos em saúde, como pressupõe o MCS. Nesse sentido, na categoria em análise, os fatores modificadores de percepção de suscetibilidade e ameaça à doença identificados foram: variáveis sóciopsicológicas, como traços de personalidade e a maneira como foram educadas, e variáveis sociais como conhecimentos sobre os fatores de risco da doença.

\subsubsection{A visão da seriedade do câncer de mama}

Ao serem questionadas sobre o que o câncer de mama mudou em suas vidas, as mulheres anunciaram os vários graus de seriedade da doença em suas vidas e de suas famílias. Elas retomaram o caminho percorrido diante do diagnóstico e dos tratamentos, deixando evidente que a seriedade da mesma é muito mais abrangente e complexa do que a simples seriedade clínica ou médica da doença, como afirmam Lescura e Mamede (1990).

A seriedade do câncer de mama, para as estudadas, é perceptível em quase todas as facetas da existência humana, trazendo implicações na mobilização de sentimentos emocionais a respeito de si mesmas, nas relações sociais e familiares, no funcionamento físico entre outros. Dessa forma, apontaram a neoplasia como uma doença impactante, desafiadora e que despertou nas mesmas o sentimento de finitude da vida.

Nessa categoria, a maioria das participantes revelou que nunca havia parado para refletir sobre a possibilidade de ser diagnosticada com câncer.

A partir da leitura dos relatos das mesmas, observamos que, antes do aparecimento da neoplasia de mama, muitas delas se sentiam invulneráveis à doença. Prova disso é a 
perplexidade que apresentaram no momento do diagnóstico, pois, para elas, aquela doença ruim só aconteceria com outras pessoas:

"A hora em que o médico falou que era mesmo aquilo, parece que o mundo desmoronou na minha cabeça. Eu falei: mas não é possível?!” E1

"A gente sempre pensa que nunca vai acontecer conosco, por isso eu assustei muito quando o médico disse que eu tinha câncer” E3

"Dá muito desespero na gente, porque quando uma pessoa tem câncer, todo mundo acha que vai morrer” E1

“É muito difícil, no início você fica assim pensando que a doença não vai ter cura” E5

Essa forma de interpretar a doença grave é considerada uma representação proveniente do senso comum, entre diferentes grupos sociais, pois diversas construções culturais acerca do diagnóstico da doença ainda fazem com que a mulher sinta que está recebendo uma sentença de morte. Diante da descoberta do câncer, o medo do desfiguramento e as preocupações relacionadas à finitude da vida e à condição de saúde, bem como a angústia associada ao tratamento são comuns nas mulheres que enfrentam esse tipo de diagnóstico (PINHO et al., 2007).

A pessoa acometida por uma doença grave questiona sua existência e atribui significados para essa patologia e para seu tratamento. O câncer traz, invariavelmente, a ideia do fim da vida. O medo que se faz presente, a fragilidade sendo vivenciada de perto e o fato de refletir sobre a própria existência, o tratamento e a desejada reabilitação, remetem o indivíduo a pensar nas questões existenciais (KÓVACS, 2003).

Assim, a percepção da seriedade do câncer é verificada entre as mulheres que acreditam na possibilidade de que a doença possa resultar em morte (ameaça física $e$ existencial) e se torna também uma ameaça de natureza social, evidenciada pelo preconceito experimentado por muitas delas:

"Eu não me importava de contar pra outras pessoas, mas tem gente que é até ignorante, acha que o câncer é uma doença que pega” E6

"Lá na minha cidade, quando alguém fala que tá com câncer, todo mundo já acha que vai morrer” E4

"A gente não sabia o que era câncer, como eram os cuidados, porque na cabeça de muita gente acha que vai morrer num instantinho, deu câncer vai morrer" E1 
De acordo com Barbosa, Ximenes e Pinheiro (2004), é esperado que a mulher sofra preconceito após o diagnóstico de câncer de mama, uma vez que são vários os valores e metáforas culturalmente construídos ao longo da história a respeito do câncer. Acrescentam os autores que isso contribui para que o câncer seja considerado uma sentença de morte; suas representações remetem a uma doença cruel, corrosiva, estigmatizante e degradante:

“O que você (E1) está falando é verdade, todo mundo acha que a gente vai morrer” E2

“As pessoas veem o câncer como uma sentença de morte” E8

"Eu penso assim, tem gente que fala que não tem o que dizer pra quem está com câncer (porque acha que a pessoa vai morrer), mas isso é, na verdade, preconceito, porque uma palavra, uma oração, ajuda muito” E3

“As pessoas deixam de ajudar porque já vão logo pensando que a gente vai morrer, criam um bloqueio, ficam pensando que vamos deixar nossa família desamparada” E1

Seffner (1995), estudando o estigma e o corpo, caracteriza socialmente um estigmatizado como aquele que possui um traço que chama a atenção, uma marca que pode afastar as outras pessoas desse indivíduo, destruindo a possibilidade de atenção para outros atributos seus, fazendo com que esse ser perceba que é rejeitado pelas demais pessoas. Weihermann (2000) define preconceito como um termo que revela julgamento prévio e pejorativo dos indivíduos mesmo após esclarecimentos e surgimento de alguns fatos que o contradigam.

A interpretação que as entrevistadas fizeram do contexto social vivido diante do câncer de mama nas suas relações com outras pessoas, especialmente naquelas que permeiam visões preconceituosas sobre a doença, revela que essas mulheres foram capazes de configurar um campo de forças, de forma a resgatar o passado psicológico, projetar o futuro psicológico e viver o presente psicológico, definindo uma das dimensões do seu espaço de vida existindo num determinado momento.

As percepções das mulheres acerca da seriedade da doença não se limitaram ao momento do diagnóstico e ao estigma do câncer de mama. Elas evidenciaram que o modo como a seriedade era percebida no presente psicológico também estava relacionado a fatores modificadores, como aqueles concernentes aos tratamentos a que foram submetidas, e que se expressaram principalmente na forma de variáveis clínicas e psico-socioculturais ao longo do processo de enfrentamento do câncer de mama. 
Dependendo do tipo de câncer e do grau de estadiamento, define-se o planejamento do tratamento a ser realizado, no qual a cirurgia é largamente utilizada. De acordo com Ambrósio (2010), a representação psíquica que esse tratamento assume para as mulheres compreende, principalmente, um momento de intenso medo da morte, assim como de insegurança em relação à convivência com a falta da mama e suas consequências para o relacionamento conjugal, pois perderam um órgão que é símbolo da feminilidade, da sexualidade, da maternidade e da estética e, quando se deram conta disso, desencadearam sentimentos de tristeza e dor.

Para Cantinelli et al. (2005), por ser a mama um símbolo feminino por excelência, seu acometimento expõe as pacientes a uma série de questões emocionais, dentre elas, o seu posicionamento como mulher, atraente e feminina, e como mãe que amamenta representações comumente associadas ao gênero feminino e que são altamente valorizadas pela cultura ocidental.

Esses sentimentos podem ser observados em vários depoimentos quando questionadas sobre a reação que tiveram ao receber a notícia da mastectomia:

"Depois, eu não sabia que eu ficar sem, que ia tirar tudo, aí depois que eu vi, eu falei: ai meu Deus do céu! Aí que foi duro mesmo pra eu aceitar” E4

“A gente se sente muito mal com a falta da mama, afinal, é literalmente a falta de um pedaço da gente. Mesmo não tendo muitas vaidades, somos mulheres, não é?!” E8

"É muito difícil sabe, porque a mama é a identidade feminina. É difícil você se sentir mulher faltando um seio seu” E5

A perda da mama tem um significado construído a partir da crença social e individual a respeito da simbologia do seio feminino na sociedade ocidental, alcançando contornos significativos nos discursos das mulheres estudadas que nos mostram o quão difícil é enfrentar o sentimento da mutilação. Para Almeida et al. (2001), as reações das mulheres com câncer de mama diante da mutilação também estão relacionadas à subjetividade atribuída por elas ao sentido da mama, sendo, portanto, determinadas pela maneira como elas vivem e convivem com os seus corpos desde a infância.

Com o passar do tempo, as mulheres passam a assimilar as consequências da cirurgia, aprendem a conviver com a falta da mama, a lutar para aceitar um corpo mutilado e para se readaptar à sua nova condição (CAETANO; GRADIM; SANTOS, 2009).

Essa visão da realidade subjetiva de ser portadora do câncer de mama traduzida pelas ideias e sentimentos que as estudadas expuseram a respeito da seriedade da doença pode ser 
considerada um importante fator para mobilizar a participação e a adesão dessas mulheres em programas de saúde e de reabilitação:

"Tem horas que a gente começa a pensar, mas evita pensar porque precisamos aceitar, porque não tem outro jeito e lutar para ficar curada, que é o mais importante” E6

"Você fica abalada, mas tem que se adaptar e lutar pra vencer, por isso eu aceitei que tinha mesmo que tirar a mama” E5

"Eu achei que tirando a mama ia ser bom, eu pensei que, com certeza, se retirasse a mama às vezes resolvia o problema, não ia ter problema mais, daí retirou” E7

As mulheres, ao passar pelo processo de remoção da mama, criam uma expectativa de que não precisam mais se preocupar com a doença, como se o problema estivesse localizado unicamente no órgão afetado; assim, todas as questões relacionadas ao câncer estariam sob controle (VIEIRA; LOPES; SHIMO, 2007).

No entanto, interpretam as pesquisadas que após constatar que essa percepção era irreal, conscientizaram-se de que a seriedade percebida até então sobre a doença não era tão simples. Esse processo de objetivar uma realidade subjetiva de convivência com a doença e com seus tratamentos vai se consolidando à medida em que as mulheres identificam tratamentos a que foram submetidas como indutores de traumas de ordem física e psicológica. Muitas delas relataram que apesar das dificuldades que enfrentaram no decorrer dos tratamentos para o câncer de mama, buscaram motivações para tomada de ações positivas para a saúde:

"Esse tratamento é bem difícil, se a gente não tiver força de vontade... a gente passa muito mal, é muito pesado o tratamento... a minha fé é muito forte, mas a gente fica bem acabadinha mesmo, fica acabadinha fisicamente” E6

"O tratamento foi doloroso, sofri muito. Sofri porque fiquei doente, tive que enfrentar de cabeça erguida e graças a Deus tô aqui firme e forte” E1

"A radioterapia desgasta muito a gente, principalmente pelo fato da gente ter que ir e voltar todos os dias e a gente chega lá é muito triste, eu olhava aquele pessoal e falava assim: Nossa! Parece que tá todo mundo coma feição caída e eu não estou, será que eu tenho que ficar assim? Abatida assim?” E2

"Cada vez que eu ia fazer a quimioterapia, eu voltava muito mal. Embora na segunda quimioterapia eu já tinha tido a primeira reação, eu não gostei de fazer, mas eu sabia que se eu não fizesse o pior seria pra mim” E7

"Eu não sentia bem com o remédio (Tamoxifeno) eu tomo ele, mas daí o médico falou que pode dar umas reações mesmo, que amarga a boca, que pode dar alguma reação, daí ele (o médico) até cortou agora” E8 
De acordo com o MCS, o grau de percepção e motivação que se tem sobre uma realidade é influenciado pelo passado, pelo presente e pelo futuro psicológico do indivíduo. Os depoimentos das mulheres retratam tal assertiva na medida em que fatos passados, presentes e futuros foram identificados por elas como elementos determinantes que as levaram à percepção da real situação de saúde a que estavam submetidas e, a partir da qual, foram capazes de criar um reservatório de energias assimiláveis às necessidades percebidas.

Assim, o câncer de mama e seus tratamentos impõem à mulher uma nova rotina de vida, que exige adaptações e grandes esforços, tanto dela como daqueles que lhe são próximos, para que esse processo não maximize o sofrimento já causado pelo fato de estar acometida pela doença.

O tratamento com a quimioterapia, que provoca a queda dos cabelos, emagrecimento ou aumento de peso, entre outros eventos adversos; a cirurgia de mama, com retirada total ou parte dela, além de algumas complicações, como o linfedema de braço, modificam a imagem corporal e, muitas vezes, provocam o isolamento da mulher, pelo fato de ela se sentir constrangida em ter de dar explicações sobre a doença que a acometeu e sobre seus desdobramentos (PINHO et al., 2007).

Passados os períodos de choque da notícia do diagnóstico de câncer de mama e da realização dos tratamentos, apesar do medo de o câncer reaparecer, as mulheres se sentem mais fortes por já terem vencido algumas etapas (CAETANO; GRADIM; SANTOS, 2009). Isso aparece nas falas abaixo:

\footnotetext{
"Eu fiquei com muito medo quando fiquei sabendo da notícia da doença. Fui pra casa e chorei muito, mas depois levantei a cabeça e fui à luta, e daí eu fui vencendo os problemas” E5

"Na hora que eu fiquei sabendo eu fui andando, andando e só chorava, mas depois aceitei, porque eu sabia que deveria fazer tudo certo e confiar que ia me curar" E7
}

Esse processo de mobilização de percepções de seriedade sobre a doença é explicado pelos pressupostos do MCS. Ao avançarem nas fases do tratamento, as percepções mudam porque as etapas atravessadas se tornam passado psicológico, fazendo-as projetar um futuro psicológico que as conduza a um melhor enfrentamento de todo o processo desencadeado pela doença (LESCURA; MAMEDE, 1990).

Assim, as próprias mulheres começaram a se mobilizar assumindo a doença, quebrando tabus e enfrentando o preconceito; passaram a ser ativas, querendo ajudar as pessoas e mostrar sua condição para os outros indivíduos. De acordo com os fundamentos do 
MCS, as mulheres deixam em evidência que a consciência e a percepção da situação de suscetibilidade e de seriedade impostas pela doença favoreceram sobremaneira a promoção de mudança de posição nos seus espaços de vida, evidenciada nos relatos a seguir:

"Chegou um momento que eu decidi que não ia me esconder, ia sair normalmente de lenço, ia contar para quem quisesse saber” E4

"Depois você acaba é ajudando, quando chega alguém no grupo que tá lá naquela fase horrível, na fase inicial disso tudo, você vai lá e dá uma palavra de conforto, de quebrar preconceitos” E3

Assim, a partir do início do processo de enfrentamento do câncer de mama, desde o diagnóstico até a realização dos tratamentos, a noção de seriedade do câncer de mama passa a ocupar uma posição central no espaço de vida das mulheres acometidas, no entanto não mais movida por vetores negativos como aqueles de natureza cognitiva e cultural relacionados à doença. O desejo e a esperança de curar-se e a própria convivência com a doença provocaram mudanças substanciais em seus espaços de vida e, consequentemente, uma mudança comportamental em seus estilos de vida.

Desse modo, elas se mostraram confiantes na cura e se descobriram dispostas a lutar pela vida. No processo de enfrentamento da patologia, consideraram-se, sim, suscetíveis e necessitadas de auxílio. As estratégias que adotaram na luta contra o câncer foram, primeiramente, prender-se à fé em Deus, seguida da aceitação de auxílio da família e de apoio social de uma maneira geral.

A fé em Deus se mostra nas falas a seguir:

"Eu não fiquei com depressão, não fiquei preocupada porque eu sou uma pessoa assim que eu confio muito em Deus” E2

"Eu falo que tudo na minha vida é Deus, se não fosse a minha fé, eu me apegar a Ele, não tinha vencido” E8

Para Pinho et al. (2007), ao afirmar que a religião ajuda a vencer o medo da morte, das perdas, do sofrimento e na afirmação da expectativa da cura das doenças, as mulheres afirmam a restituição do significado da vida, estimulando a tomada para a ação.

Já a importância do auxílio dos familiares como suporte para o enfrentamento do câncer, aparece nos relatos das mulheres quando afirmam que eles ajudaram, tanto financeiramente, quanto no desempenho de afazeres domésticos, além de oferecerem o apoio emocional de que elas tanto necessitaram nesse período conturbado da vida. 
Biffi e Mamede (2010) apontam que, a partir do diagnóstico do câncer de mama e de seus tratamentos, ocorrem mudanças em relação ao desempenho de papéis assumidos pelas mulheres, principalmente naqueles desenvolvidos junto ao lar, em função da restrição das atividades domésticas, em decorrência da limitação de movimentos imposta pela cirurgia e da debilidade física provocada pelos tratamentos invasivos, o que leva ao desempenho de novos papéis para portadoras da doença, gerando um processo de reorganização da estrutura familiar.

Já em relação aos comprometimentos emocionais da doença, Biffi e Mamede (2010) afirmam que o apoio dos familiares, de amigos ou de outras pessoas são de suma importância durante o tratamento e a reabilitação da mulher, pois contribuirão positivamente no trajeto da mesma nesse período. Acrescentam as autoras que o afeto familiar auxilia a mulher a lutar contra a doença, conseguindo suprir suas carências emocionais e alcançando uma maior aceitação e estabilidade comportamental (BIFFI; MAMEDE, 2009).

No contexto do presente estudo, compreendemos que, para as mulheres, a família é considerada um sistema social humano com características distintas, composta por indivíduos com atributos igualmente singulares, que mantêm entre si laços de consanguinidade ou socioafetivos, como afirma Szymanski (2002): “Hoje a gente tem muito apoio, tive apoio da minha família, do meu esposo,
das pessoas amigas. Eu tive apoio de muita gente e acho que isso aí ajuda
muito” E1

"Quando a gente tá numa situação desta, os amigos, as visitas, são muito importantes, acho que a amizade nestes momentos faz muito bem pra gente. Minhas amigas iam em minha casa e arrumavam tudo, deixavam tudo muito limpo e o meu esposo até hoje lava louças para mim” E3

“Tem amigo que é mais chegado que um irmão” E3

"As amizades são muito importantes num momento desses, de enfrentar a doença, tem amigos que são como se fossem da família mesmo” E2

Dessa forma, para elas, foi importante poder contar tanto com pessoas da família quanto com amigos, pois estes são essenciais num momento em que, de acordo com Souza e Espírito Santo (2008), os familiares, abalados com a presença da doença e com os efeitos indesejáveis do tratamento, podem perder sua capacidade de oferecer o apoio de que a mulher tanto necessita.

Apesar disso, de modo geral a literatura corrobora que a família, esteio fundamental para o crescimento interior da pessoa, é uma força positiva para a tomada de decisões e para a 
transformação de conceitos e comportamentos (AMBRÓSIO, 2010; CAETANO; GRADIM; SANTOS, 2009).

No tratamento e na reabilitação psicossocial da mulher com câncer de mama, torna-se primordial, portanto, o apoio proporcionado pelos familiares, amigos ou outras pessoas que exerçam influências favoráveis sobre a paciente (HOFFMANN; MULLER; FRASSON, 2006).

Para Biffi e Mamede (2009) e Santos (2008), as relações familiares estabelecidas a partir do diagnóstico de uma doença grave são inevitavelmente modificadas, sendo que pode ocorrer aumento do cuidado e proximidade entre os indivíduos da família - vivências positivas - ou isolamento, depressão e vergonha, o que constitui experiências negativas. Ou seja, uma doença como o câncer de mama pode fortalecer ou fragilizar os vínculos afetivos e, consequentemente, o envolvimento da família no cuidado, o que, por sua vez, pode contribuir de modo positivo ou negativo no enfrentamento da enfermidade.

Tais aspectos da vida cotidiana no contexto familiar foram identificados e percebidos pelas mulheres deste estudo como elementos de motivação para superar os obstáculos no processo de recuperação da doença:

“Em casa, a doença só uniu a gente (família), todos me deram muito apoio” E6

"Todos da minha família ajudavam como podiam. Mesmo a gente tendo nossas desavenças, é na doença que a gente vê que família é tudo” E2

"Mesmo sofrendo, a minha família nunca deixou de me ajudar, tinha horas que eu via que minha filha não estava aguentando o sofrimento, mas, do jeito que ela podia e aguentava, ela me dava forças” E8

"Eu ficava tranquila sabe, sabia que agora era o momento de me cuidar que, mesmo o pessoal de casa trabalhando, na hora que desse, eles cuidavam da casa pra mim” E4

“A minha nora foi um anjo, ela tomou toda a responsabilidade da casa pra ela” E7

Outras vezes, mesmo entendendo a seriedade da doença e a necessidade de ajuda para as atividades cotidianas, algumas mulheres mostraram que nem sempre se sentiram confortáveis com a situação instalada na dinâmica familiar, durante o processo de reabilitação:

"Ficava muito pesado pra minha família ter que cuidar de tudo, sempre que antes, tudo era por minha conta, mas eu estava limitada” E6 
"Eu tinha que deixar eles cuidarem da casa para mim para eu me tratar, ficava difícil pra eles, nem sabiam como era o meu sistema de ajeitar as coisas, mas eu tive de deixar por conta deles” E5

Por outro lado, algumas participantes deste estudo não puderam contar com esse apoio dos familiares ou amigos, e comentam que tiveram de buscar forças e formas para enfrentar sozinhas algumas situações, como por exemplo, as que se seguem:

"Quando você chega à quimioterapia, sempre tem um pai ou uma mãe, ou uma irmã junto, mas não tinha jeito de ninguém ir comigo porque minha mãe já era assim mais idosa, a minha irmã tinha que trabalhar, então, eu busquei forças pra encarar sozinha, mas preferi assim, porque não tem como a família da gente ficar sem trabalhar” E2

"Daí, ele (o médico) perguntou: mas você não tem família? Porque eu sempre tava sozinha na quimio, aí eu falava: eu tenho família, graças a Deus, não tem como a minha família ficar comigo o tempo todo, eles (filhos) precisam trabalhar. Sei lá, é Deus que dá uma força assim que você nunca imaginava que tinha e a esperança faz a gente assim” E4

Entendemos que essas falas não retratam uma postura indiferente das mulheres diante dessa situação, nem mesmo a ausência de necessidade do apoio da família, mas, sim, revelam a utilização de estratégia de enfrentamento, ou seja, de assumir uma postura de aceitação apesar da percepção das dificuldades de estar sozinha nesse momento. À luz do MCS, nos é permitido entender que a percepção exata, pelas mulheres, da dimensão da seriedade da doença, as motivou a enfrentar as dificuldades e barreiras para a adesão aos tratamentos propostos.

Acrescentamos que a tentativa de fazer com que a doença não desestabilizasse a rotina familiar, e também não levasse a uma sobrecarga (física e/ou emocional) dos que as rodeavam, e ainda a busca pela resolução de outras dificuldades que foram surgindo no processo de reabilitação levou as mulheres a procurar outra forma de apoio social, além da família, da religião e dos amigos. Assim, a tomada de decisão por buscar apoio em um grupo especializado em reabilitação foi percebida como uma alternativa, especialmente por considerarem a necessidade de orientações especializadas para o enfrentamento das dificuldades a serem vivenciadas.

\footnotetext{
"Eu estava muito sensível, chorava muito e, muitas vezes, achava que a minha família somente e os amigos não teriam como me ajudar. Além de ficar firme em Deus, eu precisava de um atendimento especializado” E2

"Eu busquei o grupo porque ninguém na minha casa sabia mexer com essas coisas, curativo, dreno, e tudo assustava muito a gente” E3
} 
Assim, a busca pelo grupo de reabilitação mostrou-se como uma forma de suprir necessidades de cuidados que somente uma equipe profissional poderia oferecer.

Esses resultados nos permitem compreender que os determinantes dos comportamentos das mulheres em relação ao enfrentamento da doença são de distintas naturezas, ou seja, alguns de natureza psicológica (perplexidade com o diagnóstico, medo da morte, perda da mama e traumas advindos dos outros tratamentos); outros, de natureza sociológica (interferência nas relações sociais e familiares); e, ainda, outros de natureza situacional (rearranjos sociais e familiares), em função do grau de seriedade com que elas perceberam seu mundo subjetivo naquele momento de suas vidas.

\subsubsection{Os estímulos para a ação: a busca de apoio no grupo de reabilitação}

Rosenstock (1990) aponta que os níveis de suscetibilidade e seriedade fornecem força e energia para o indivíduo agir e a percepção dos "benefícios menos barreiras” direciona o curso da ação. Entretanto, a combinação desses fatores, apesar de alcançar níveis consideráveis de intensidade, pode não resultar em uma ação, necessitando de um evento instigante para estimular o comportamento apropriado de saúde. Na área da saúde, tais eventos ou estímulos para a ação podem ser internos, como a percepção do estado corporal, ou externos, como as interações interpessoais, o impacto da mídia e sociedade, nesse caso apontando a seriedade do câncer de mama, os lembretes de profissionais de saúde, como avisos médicos, e o conhecimento de alguém que foi afetado pelo problema.

A intensidade do estímulo necessário para iniciar a ação dependerá da percepção da suscetibilidade e de seriedade da doença. Assim, uma baixa aceitação da suscetibilidade e da seriedade da doença necessitará de estímulos mais intensos para desencadear uma resposta e vice-versa.

A ciência da motivação se debruça na perspectiva de que os comportamentos de promoção à saúde são determinados a partir das considerações que a pessoa faz em relação às possibilidades ou às expectativas de problemas ou ameaças à sua saúde e acima de tudo sobre a probabilidade de redução de tais ameaças por meio de atitudes consideradas adequadas àquela questão em particular (LESCURA; MAMEDE, 1990).

Os achados do presente estudo trazem importantes revelações para o entendimento de como se configura o processo motivacional para a adesão de mulheres com câncer de mama a 
grupos de apoio em reabilitação. As participantes revelaram o quanto perceberam a sua suscetibilidade aos agravos à doença e à seriedade dos mesmos, o que as levou a pensar em novas maneiras de organizar suas vidas e a estabelecer nos seus espaços de vida novas prioridades. Assim, procuraram ampliar sua rede de suporte para além das relações familiares, religiosa e com amigos. A participação em grupo especializado em reabilitação foi apontada por elas como fundamental para a reconfiguração de um espaço de vida saudável.

Desse modo, na busca de novas formas de auxílio para enfrentar a doença e seus tratamentos e os abalos em seus modos de viver, as mulheres recorreram ao MUCAMA. De acordo com Zimerman e Osório (1997), o grupo de reabilitação se caracteriza por um grupo terapêutico e homogêneo, que visa congregar pessoas que passam por sofrimento idêntico, oferecendo atendimento especializado em reabilitação.

As mulheres estudadas referiram alguns fatores que serviram de estímulo para buscarem participar do grupo de reabilitação, como a própria vivência do câncer de mama e a necessidade de orientações que se constituíram em poderosos estímulos internos para a prevenção e para a detecção precoce de possíveis complicações e de recidiva da doença:

"Se a gente já teve a doença não pode deixar de cuidar, porque eu sei o que já passei e não quero ter que enfrentar tudo de novo” E7

"Eu procuro me cuidar, faço todos os exames certinho, sempre aqui no grupo as enfermeiras me orientam de que eu não posso deixar de me cuidar” E5

"Você vê que tem que sempre continuar se cuidando, a gente tira experiência pelas colegas que, infelizmente, tiveram metástase” E2

As orientações dos profissionais de saúde e a troca de experiências com as pessoas da rede social, citadas como fontes de referência para seu conhecimento, podem atuar como estímulo externo (LESCURA; MAMEDE, 1990). A existência de membros da família e de pessoas conhecidas que tiveram câncer pode atuar como fator determinante para a conduta dessas mulheres ao adotarem um comportamento preventivo em saúde e aderirem às orientações fornecidas no grupo de reabilitação, pois puderam vivenciar o sofrimento experimentado por essas pessoas na trajetória da doença:

"Sempre a gente é orientada pelos profissionais aqui do grupo e as próprias colegas estimulam a gente que não podemos deixar de vigiar, de sempre fazer as consultas de retorno”E1

“Na minha família tem casos, por isso eu sei que preciso sempre me cuidar” E7

“Eu vi muita gente sofrer com o câncer, por isso não deixo de me cuidar” E4 
Desse modo, o fato de conhecerem pessoas que passaram por sofrimento semelhante parece ser um fator propulsor (estímulo para a ação) para as mulheres se cuidarem, assim como no estudo realizado por Caetano, Gradim e Santos (2009), no qual as mulheres, ao discorrerem sobre o enfrentamento do câncer de mama, revelaram que a vivência do câncer na família influenciou as formas como enfrentaram também a sua doença.

Além do conhecimento sobre a vivência da doença em algum membro da família ou amigo, outras crenças individuais relativas à seriedade da doença, como a percepção de que o câncer pode resultar em consequências negativas na sua vida familiar, social e ou sexual ou mesmo levar à morte, foram expressas pelas estudas como uma forte motivação para elas buscarem ajuda profissional no grupo de reabilitação e adotarem comportamentos preventivos diante de qualquer alteração percebida.

Da mesma forma, as complicações relacionadas aos tratamentos são igualmente percebidas pelas mulheres como sérias consequências advindas do câncer de mama. A presença da dor, para muitas delas, foi percebida como uma valência de forte poder negativo próximo à região central de seus espaços de vida, levando-as a identificar necessidades de atenção e, portanto, de locomoção. Assim, tais necessidades as motivaram a comparecer no grupo de reabilitação:

\footnotetext{
“Eu vim porque eu tive muita dor, sentia muita dor mesmo” E4

"Depois de eu fazer a cirurgia, tive dor, daí como sabia do MUCAMA resolvi começar a frequentar e a gente vê que melhora mesmo" E6

"Quando eu estou com dor, venho aqui e a mão da fisioterapeuta é santa pra mim! As massagens são muito boas” E5

"A primeira coisa que penso quando estou com dor é chegar logo o dia de vir para o projeto porque, após o atendimento, eu não sinto mais nada” E4
}

Esse achados também estão de acordo com os resultados encontrados por Prado et al. (2004) de que a melhora da dor é apontada como um grande estímulo que leva as mulheres mastectomizadas a aderir à realização de atividades físicas, especialmente porque a literatura científica enfatiza que a prática de exercícios físicos como um hábito é de difícil incorporação.

Em um trabalho desenvolvido por Silva e Gradim (2010), no mesmo grupo de reabilitação do presente estudo, as autoras referiram que sintomas dolorosos eram queixas comuns e causa principal da procura pelo serviço. 
Outro elemento de forte impacto para a procura pelo grupo de reabilitação foi o medo de outra complicação como o linfedema, ou seja, o “braço inchar”, assim referido pelas mulheres:

"Eu tinha muito medo de o meu braço inchar, como eu vi o caso de outras mulheres que tiveram o câncer de mama” E4

"Eu achei que frequentando o MUCAMA iria ser bom, porque daí a gente prevenia de o braço inchar” E6

"Eu gosto muito que aqui vocês cuidam do braço da gente, a semana que eu não venho eu já sinto a diferença, parece que o braço fica mais pesado” E1

"Ah, com a gente vindo aqui, fica menos preocupada, porque medem o braço da gente e daí a gente fica com menos preocupação dele inchar” E8

A possibilidade de aparecer o linfedema foi, portanto, objeto de preocupação para essas mulheres, visto que, diante de sua ocorrência, simbolicamente ele se constitui num sinal visível e representativo da doença (ALMEIDA et al., 2001).

Assim, mesmo no pós-operatório tardio em que havia a melhora do quadro álgico, as mulheres se preocuparam com sua reabilitação e buscaram o grupo por causa do medo de adquirir o linfedema.

A possibilidade da reincidência também é traduzida pelas mulheres como medo; apontando experiências vivenciadas por outras mulheres com a recorrência da doença cujos relatos sinalizavam certo temor, reforçando a seriedade da doença, mobilizando-as à aderência aos tratamentos e à prática do autocuidado. A busca pela não reincidência da doença trouxe a elas consciência da necessidade de mudar os hábitos de vida, implicando a valorização delas mesmas e o cuidado com sua saúde.

Assim, a preocupação constante com as complicações ou com a reincidência, como forma de expressar a percepção da seriedade da doença, serviu como força para que as mulheres adotassem comportamentos de promoção à saúde, adesão às atividades oferecidas pelo grupo de reabilitação e introdução de mudanças nos seus hábitos de vida.

Cabe destacar que outras forças identificadas por elas como de valências positivas para a tomada de decisão em procurar o grupo de reabilitação foram as orientações e as recomendações de profissionais de saúde, integrantes de redes de apoio social, como a Associação Vida Viva, e de familiares que estimulavam as mulheres a frequentarem e a aderirem às orientações empreendidas no grupo de reabilitação:

“Eu vim porque o médico me encaminhou” E4

"Eu recebi muita ajuda da Vida Viva, inclusive quando eles me encaminharam pra cá” E5

"A minha nora me trouxe ao serviço e me deu muito apoio para eu participar, porque sabia que seria bom pra mim” E6 
A possibilidade de participação em um grupo especializado em reabilitação de mulheres com câncer de mama foi considerado, pelas participantes, como um campo de forças dirigidas para uma mesma região, anunciando, portanto que a inserção definitiva no grupo é um objetivo vivencial e de grande relevância em suas vidas. As falas a seguir revelam a dimensão percebida sobre a participação no grupo:

\footnotetext{
“Agora é mais difícil dele (câncer) me pegar, porque agora eu faço tudo certinho” E3

"Sabe, a gente acha que ele (câncer) sumiu, mas ainda assim eu tomo o remédio (Tamoxifeno) e faço o que vocês orientam aqui no grupo, porque vejo que tem umas colegas que ele volta depois de muito tempo, não podemos deixar de vigiar” E5
}

\subsubsection{Benefícios e barreiras percebidos na decisão sobre participar do grupo de reabilitação}

A percepção da suscetibilidade e da seriedade da doença pode motivar o indivíduo a tomar uma determinada conduta, porém não define o curso da ação a ser realizada. O que direciona a ação são as crenças pessoais relativas à eficácia das alternativas conhecidas e disponíveis para diminuir a ameaça da doença, ou seja, a percepção dos benefícios de se tomar a ação e não os fatos objetivos que mostram a eficácia da ação (ROSENSTOCK, 1990).

Os achados deste estudo mostram a presença de vários benefícios identificados pelas estudadas em participar de grupos de reabilitação assim como barreiras para a inserção e manutenção regular às atividades ali propostas foram descritas.

\subsubsection{O retorno às atividades cotidianas e a reabilitação psicossocial}

Na dimensão dos benefícios relativos à sua participação no grupo de reabilitação, as mulheres expuseram a melhora do desempenho físico e a possibilidade de retorno às atividades cotidianas:

"Pra mim, o melhor do grupo é a gente poder voltar a cuidar das coisas da gente, da casa da gente e ter mais disposição” E5 


\begin{abstract}
"Os exercícios, não é?! Eu fico mais bem disposta quando venho aqui me exercitar” E3

“Eu adoro os exercícios, fico mais relaxada e motivada” E8

“Com os exercícios a gente fica mais disposta e até dorme melhor” E2

"Eu gosto muito dos exercícios porque senti que depois que eu comecei a praticá-los, eu melhorei os movimentos do braço, porque quando a gente faz a cirurgia, acha que tem que ficar com ele quietinho, ninguém avisa pra gente” E7
\end{abstract}

Fernandes et al. (2005) apontam a retirada da mama como um processo cirúrgico agressivo, sendo que a cirurgia expõe as mulheres a uma série de dificuldades que envolvem mudanças físicas, como a limitação dos movimentos do membro superior correspondente à mama afetada, chegando a impossibilitá-las de realizar atividades domésticas e profissionais. Assim, o trabalho desenvolvido no grupo por uma equipe multiprofissional pode contribuir sobremaneira para o retorno das mulheres ao seu cotidiano e às suas atividades.

No grupo de pacientes mastectomizadas, os profissionais podem atuar de maneira preventiva, por meio de atividades grupais, exercícios dinâmicos e de incentivos para que as mulheres passem a ter uma rotina de atividades. Desse modo, podem relembrar de forma continuada os cuidados diários necessários à nova situação de vida (STUMM et al., 2009).

De acordo com Gutiérrez et al. (2007), a principal meta da reabilitação física em mulheres que sofreram uma mastectomia é prevenir possíveis complicações, possibilitando a elas o aumento da amplitude dos movimentos do membro superior homolateral à cirurgia. Os benefícios dessa prática podem ir além da dimensão física, obtendo-se também resultados promissores para o ajustamento psicossocial devido ao fato de elas conseguirem o retorno, mesmo que não por completo, às suas atividades cotidianas.

Corroborando com o estudo realizado por Prado et al.(2004), os benefícios da reabilitação física são os mais bem avaliados pelas mulheres com câncer de mama e a sua prática regular promove o seu retorno às atividades cotidianas, proporcionando, consequentemente, um bem-estar psicossocial e uma melhora da qualidade de vida.

A percepção da melhora física atribuída pelas mulheres deste estudo ao fato de o membro homolateral à cirurgia permanecer sem alterações também mostrou a importância atribuída por elas aos benefícios de aderir às orientações fornecidas no grupo pela equipe multiprofissional.

Assim, o conhecimento sobre a percepção dos benefícios e das barreiras a respeito das atividades físicas empreendidas no grupo pode ser um importante indicador para o 
desenvolvimento de programas de reabilitação de mulheres em risco de apresentar limitações físicas, como é o caso das mastectomizadas.

Em consonância com os pressupostos do MCS, a percepção das mulheres sobre os benefícios da adesão às atividades do grupo de reabilitação funcionou como uma mola propulsora para a tomada de decisão sobre sua participação sistemática no grupo, favorecendo a assimilação das orientações empreendidas no grupo de reabilitação, a aquisição de práticas saudáveis e de promoção à saúde:

\footnotetext{
"Eu acho que se você vem aqui no grupo e faz certinho o que as profissionais orientam, a sua vida após o câncer fica muito melhor e você tem menos chance de ter uma recorrência da doença” E1

"Eu considero que é muito importante seguir as orientações aqui no grupo, isso faz a gente se sentir melhor, sentir que está se cuidando e que tem mais chances de ficar livre da doença” E4
}

Outro benefício identificado pelas mulheres diz respeito à possibilidade de esclarecimentos de dúvidas pelos profissionais do grupo, uma vez que a falta de informações durante o curso da doença e seus tratamentos foi uma realidade vivenciada como identificado nas falas abaixo:

\footnotetext{
"Ninguém (profissionais de saúde) explicava nada direito pra mim, foi somente depois que vim participar do grupo é que entendi muita coisa da minha doença” E8

"A gente não tinha assim antes uma orientação como a que conseguimos aqui no grupo” E7

"Sabe, eu fiquei muito chateada na época do meu tratamento porque as informações que recebia eram muito vagas, não entendia direito” E4
}

Assim, percebemos que o temor das complicações, como a recidiva, aliado à percepção dos benefícios físicos da adesão às atividades e às orientações empreendidas no grupo, colaboram para a tomada de ação das mulheres em adotar comportamentos saudáveis em suas vidas. Encontraram apoio no grupo de reabilitação, ampliaram o nível de cognição sobre a patologia que as acometeu e buscaram conscientizar-se sobre a realidade subjetiva e, consequentemente, qualificaram o seu papel de mentora da sua própria história e de sua saúde.

Portanto, conscientes da vulnerabilidade e da seriedade a que estavam sujeitas, e esclarecidas sobre a possibilidade de complicações, elas incluíram em seus espaços de vida o grupo de reabilitação de forma a fazer parte de seu cotidiano. 
Estudos revelam que as mulheres se abalam não somente pelo choque do diagnóstico de câncer de mama, mas também por não terem recebido um suporte informativo e emocional durante o tratamento da doença (CAETANO; GRADIM; SANTOS, 2009; RODRIGUES; SILVA; FERNANDES, 2003).

A existência de lacunas quanto à prestação de informações claras às mulheres mostra o relevante papel dos profissionais de saúde, especialmente dos enfermeiros, em oferecer estratégias de acolhimento e atendimento humanizado às mulheres mastectomizadas de forma a facilitar o processo de reabilitação física e psicossocial (FUGITA; GUALDA, 2006).

A partir dos relatos das estudadas, percebemos que estas percebem a participação no grupo como forma de atendimento às suas expectativas na resolução de muitos de seus problemas, especialmente aqueles relacionados à melhoria de qualidade de vida:

“Aqui no grupo é muito bom porque toda dúvida sua é esclarecida, aí você não fica com bobagens à toa na cabeça” E8

"Eu me sinto segura aqui, vejo que toda vez que eu tiver uma dúvida, posso vir e perguntar sem receio” E1

"É muito bom saber que podemos contar com vocês para retirar nossas dúvidas. Eu mesmo quando tenho uma coisa que está me inquietando, fico bem quando venho aqui e vocês me orientam” E4

O desenvolvimento de grupos de apoio a mulheres com câncer se deu com o intuito inicial de fornecer informações a pacientes sobre diagnósticos terminais e tratar de assuntos como a qualidade de vida e as necessidades psicossociais dos pacientes no planejamento do tratamento. Nos dias atuais, os efeitos psicossociais da terapia de grupo em pacientes com câncer se revelam positivos, incluindo melhora no estado de espírito e no ajustamento (GOMES et al., 2003).

Assim, foi possível identificar que há um consenso sobre os benefícios e a eficácia da participação em grupos de reabilitação, em cujo espaço as mulheres podem encontrar segurança e respostas para as suas dúvidas e inquietações sobre a doença, sobre os tratamentos e suas consequências.

"Eu gosto, eu acho bom. É ruim ter um caso desse e viver isolada. Às vezes a gente está cheia de problemas em casa, chegando aqui passa tudo” E2

"Estava muito sensível, qualquer coisa eu estava chorando, me aborrecendo facilmente. Não queria ser um peso para a minha família, eles me ajudavam demais, mas eu via que faltava uma orientação, uma ajuda, daí foi quando a minha nora, que é enfermeira, me convidou” E6 
"A minha filha e eu, logo que ficamos sabendo do MUCAMA, decidimos que eu deveria vir. Eu logo achei bom, porque eu, mesmo sofrendo com o tratamento, estava decidida a procurar toda a forma de ajuda para me curar, eu ainda tinha muitos planos” E5

Ao expressarem os benefícios percebidos em sua participação no grupo, foi marcante também a satisfação com que cada qual falava sobre o papel da equipe multidisciplinar.

\begin{abstract}
"Eu precisava muito da fisioterapia, cheguei aqui e encontrei tudo que eu precisava. As enfermeiras também foram logo me acolhendo e as alunas preenchendo toda a fichinha pra saber do meu caso e vendo a cicatriz como estava, foram muito atenciosas” E4

"Gostei muito de toda a equipe, você fica feliz em se sentir acolhida, em ter toda aquela atenção dos profissionais para o seu problema” E6
\end{abstract}

Percebemos que as mulheres expõem o quanto é importante a relação com a equipe e como se sentem amparadas com os cuidados despendidos pelos profissionais. Franco (2011) comenta que a qualidade do cuidado integral dar-se-á com as informações coordenadas pela equipe multiprofissional e isso dependerá da confiança que tais mulheres depositam no cuidado ali recebido.

Desse modo, reforçam Popim e Boemer (2005) que, no cuidar em oncologia, da fragilidade que emana de cada paciente e da disposição pessoal do profissional para atender as suas necessidades vai se construindo uma relação de compromisso, permeada por solidariedade, ternura e apego mútuos, para que os significados deixam de ser individuais para configurar um sentido social:

"Os profissionais são muito atenciosos e se preocupam com o nosso bemestar; aqui eu me sinto acolhida” E2

"Eu acho que os profissionais gostam mesmo de trabalhar com a gente, porque eles não fazem por obrigação, fazem porque gostam, eu acho” E3

"Eu acho legal como os profissionais trabalham aqui, me sinto bem porque aqui somos como uma turma, a gente conversa, ri e se cuida” E4

"Eu acho que os profissionais são bem dedicados e preparados, mesmo as alunas que ainda não são formadas sabem orientar a gente” E1

"Pra mim é bom demais o trabalho que vocês fazem aqui, a gente fica muito satisfeita” E5

O processo de reabilitação depende em larga medida da formação de uma equipe multiprofissional que trabalhe de forma integrada e mantenha um relacionamento satisfatório 
com a mulher portadora de câncer de mama e com seus familiares. A equipe deve estar disponível para oferecer informações sobre a doença e sobre suas possíveis complicações, além de estar preparada para acolher essa paciente em suas dificuldades (CHO; YOO; KIM, 2006).

Os relatos das entrevistadas demonstraram também que elas perceberam a integralidade da assistência prestada pelos profissionais que as atendem no grupo, contemplando suas necessidades físicas e psicossociais. Sentiram uma energia positiva emergir das conversas entre elas e das discussões no grupo, como a “roda da dúvida” e a “conversa terapêutica”. Participar do grupo, para elas, é uma oportunidade singular de falarem e serem ouvidas sobre os sentimentos e vivências de serem portadoras de câncer de mama:

"Eu gosto muito da atenção de vocês, sempre estão preocupadas em saber como a gente está e do que tá precisando” E5

"Me sinto muito bem aqui, aqui eu posso falar, ser ouvida pelos profissionais e também escutar” E7

Para Sant’anna et al. (2010), os fatores determinantes para a adesão aos programas de reabilitação são os relacionados principalmente à confiança, adquirida pela mulher para com o profissional envolvido no seu cuidado, conquistada na medida em que ela encontra acolhimento e compromisso do profissional em seu processo de reabilitação.

As mulheres revelaram ainda que, transcorrida a fase de adaptação no grupo, conseguiram se visualizar como membros dele e passaram a perceber benefícios psicossociais de sua participação no serviço, benfeitorias observadas por meio da convivência com outras pessoas, também portadoras de uma doença estigmatizante, que as ajudaram a se encontrarem em meio a iguais e a compartilhar experiências.

"No grupo, eu encontrei um refúgio sabe, vi que eram muitas pessoas que passavam por uma situação como a minha” E3

"Eu achei muito valiosa a participação no grupo porque aqui a gente convive com pessoas como nós mesmas, passando pelos mesmos problemas, aí você vê que não está sozinha” E5

"Quando eu cheguei aqui (MUCAMA) e percebi que tinha muita gente como eu, eu fui confortada e ainda as colegas me ajudaram muito, sempre falando das experiências delas” E8

Pereira et al. (2006) revelaram que as mulheres, ao compartilhar suas experiências, percebem que não estão sozinhas na luta contra o câncer de mama, falam da doença e da 
cirurgia, sem medo da rejeição e do preconceito, muitas vezes emanando verdadeiras amizades.

Os benefícios emocionais e psicossociais da prática grupal em reabilitação são bem documentados na literatura como reconhecidos pelas próprias mulheres. Gottlieb e Wachala (2007) realizaram uma revisão na qual apontaram que a participação em grupos de suporte e de reabilitação para mulheres com câncer de mama é um tipo de experiência que propicia aos seus integrantes sentir-se confortados pela vivência grupal e afastar sentimentos de solidão.

As falas abaixo confirmam essas ponderações:

"Aqui parece que eu me sinto mais perto de uma identidade. Estar perto de quem vivencia o problema da gente é bom” E7

“Aqui eu nunca me sinto sozinha, tenho as colegas pra desabafar” E4

Os seres humanos são seres sociais por natureza e a doença "câncer" faz a pessoa acometida se sentir diferenciada e excluída da sociedade. Para que isso se reverta, Pinheiro et al. (2010) consideram necessário o trabalho de grupos especializados em reabilitação, que ajudem a mulher a se encontrar novamente entre os seres “iguais”. Assim, ela perceberá que não está só, saberá que pode trocar experiências de dor, de sentimentos de tristeza e de alegria e redescobrir a vontade de viver.

Conforme reforçam Pereira et al. (2006) e Fernandes et al. (2005), a convivência com outras mulheres que receberam diagnóstico de câncer de mama estimula a transformação do medo, uma energia negativa, em força vital, incentivando o autocuidado e valorizando cada mulher como um ser único. O benefício gerado nesses encontros pode proporcionar às suas integrantes uma enorme energia que pode ser carregada para o seu espaço de vida, colaborando para a sua ressocialização e recuperação:

\footnotetext{
"Para mim, é bom demais estar aqui, você fala do seu problema e escuta o problema da colega, a gente chega a um ponto de amizade que, mesmo quando estou em casa, penso no problema da outra, se ela já está melhor ou não. Você tem oportunidade de falar o que está sentindo e o que precisa. Aqui, todo mundo se ajuda” E3

"É interessante porque você vai vendo as outras pessoas que têm câncer e você mesmo vai percebendo que a gente forma um grupo que se ajuda. Com as colegas aqui a gente dá risada e desabafa. Uma escuta a outra, sabe como estão indo os exames, as consultas” E2
}

Em uma revisão realizada por Gomes et al. (2003), os autores, após a análise da literatura científica sobre a utilização de grupos para mulheres com câncer de mama, 
afirmaram que a convivência em grupos constituídos por pessoas que atravessam problemas semelhantes proporciona uma experiência que pode desenvolver resultados extremamente benéficos para a reabilitação das pacientes.

Assim, a receptividade e a posterior convivência com as demais mulheres e com os profissionais propiciou a interação grupal. Isso ajudou atravessar possíveis barreiras que poderiam ser criadas por sentimentos de solidão e de isolamento social. Algumas entrevistadas comentaram que, na primeira vez que entraram em contato com o núcleo e com as outras mulheres, sentiram-se estranhas ao ambiente, fato que talvez seja atribuído ao estigma que as próprias mulheres reconhecem antes da imersão no grupo. Quando elas encontravam mulheres portadoras de câncer de mama sorrindo e bem dispostas no grupo, isso lhes provocava uma estranheza:

\footnotetext{
"Nas primeiras vezes que eu vim, estranhei muito, todo mundo alegre. Eu pensava: mas, como é possível?! Fiquei até um pouco nervosa com aquilo, mas depois eu vi que ali era um local de superação, todas as meninas recebendo a gente muito bem. Engraçado que desde a primeira vez que eu vi a moça que conduz os exercícios, eu tive uma afinidade muito grande com ela, não sei o porquê” E4

"No início, a gente estranha aquela alegria toda das meninas, mas depois vê que é porque o grupo faz a gente ficar melhor” E6
}

Portanto, chegar ao grupo pela primeira vez parece tê-las obrigado a entrar em contato com a doença novamente, o que poderia fazer aflorar seus conceitos de câncer como uma patologia letal, mas, mesmo com o sentimento de estranheza, ao perceberem que a patologia também se fazia presente na vida de outras mulheres que ali estavam, aos poucos foram se sentindo parte desse grupo e o considerando como local de superação. Assim, ao continuarem a participar dos atendimentos, perceberam os benefícios de sua adesão às atividades empreendidas no grupo.

Muitas das estudadas disseram que atualmente empreendem mais tempo no cuidado de si, inclusive participando do grupo, pois no passado esse tempo era dedicado a outros afazeres, como cuidar dos filhos, do marido, da casa, mas que, agora, cuidar de seu bem-estar é algo fundamental para seu processo de saúde:

"O grupo me fez muito bem sabe, antes eu não tirava tempo pra mim, só ficava pensando em cuidar de casa e de marido, hoje eu cuido de mim” E7

"Hoje em dia não é qualquer coisa que me tira do sério, pois eu enfrentei coisa muito pior, o câncer!” E3 
Desse modo, compreendemos que as mulheres estudadas, conscientes da seriedade do câncer que as acometia, retomaram as suas vidas, procurando conhecer mais sobre a doença e suas consequências, procurando ser mais compreensivas, pacientes e disciplinadas em relação aos cuidados com sua saúde, e dessa forma, o desenvolvimento de hábitos saudáveis adquiriram posições mais centrais em seus espaços de vida, contribuindo na recuperação da sua saúde.

Fernandes, Rodrigues e Cavalcanti (2004) identificaram que a experiência do câncer de mama possibilitou às mulheres se beneficiarem de comportamentos mais positivos em suas vidas, dentre eles: ir ao encontro de desejos não realizados, buscar uma melhor qualidade de vida, exprimir sentimentos dantes reprimidos, satisfazer necessidades, desenvolver a capacidade de dizer não e perceber mais claramente a finitude da vida. Em nosso estudo, observamos essas novas atitudes, evidenciadas nas falas:

"Eu evito fazer as coisas na correria e faço aos poucos, agora eu penso que quem gosta da gente é a gente” E1

"Hoje eu penso no que eu quero fazer: sair, passear, eu passeio, mas eu escolho o lugar que eu quero ir, eu falo que agora, depois de tudo que eu já passei, agora eu faço o que eu quero, se eu não quero sair, eu não saio, se eu não quero ir a determinado lugar, eu não vou... antes a gente ia porque era social... Minha cabeça mudou porque eu acho que não vale a pena a gente viver de aparências. Com certeza, me ensinou algumas coisas, não veio por acaso” E2

Assim, alterar o cotidiano permitiu às mulheres pesquisadas incorporar um novo padrão de vida em que atividades de lazer e bem-estar que antes eram pouco valorizadas fossem consideradas alternativas para uma vida melhor.

Essa observação assemelha-se à de Almeida (2006) de que apesar da experiência tida como sofredora de passar por um câncer de mama e por seu tratamento, após ele, as mulheres passam a se concentrar em aspectos positivos da vida e descobrem o quão valiosa e gratificante ela ainda poderia ser.

Assim, as mulheres participantes deste estudo revelaram sentir-se ajudadas com a oportunidade de dividir experiências e fatos, podendo também ajudar outras mulheres, oferecendo estímulos e compartilhando dúvidas e inseguranças, dados também encontrados por Franco (2011) e Pinheiro et al. (2008), ao investigarem a experiência de mulheres com câncer de mama participantes de grupos de reabilitação:

"É uma troca sabe, tem dias que uma colega não está bem e você oferece um ombro amigo, ou tem dia que é você quem não está bem, aí vem a fisioterapeuta e faz uma massagem e aí a gente já melhora (risos)” E8

"Eu sou muito feliz aqui, não troco isso por nada! Aqui eu tenho verdadeiras amizades” E7 
Rotineiramente, nas reuniões do MUCAMA, são reservados momentos em que as mulheres interagem, particularmente, entre si. Nessas ocasiões, elas percebem que não são as únicas a ter câncer. A partir dessa percepção, descobrem que podem se ajudar mutuamente, uma vez que uma mais experiente pode esclarecer dúvidas da outra, aconselhá-la e até mesmo apoiá-la, dependendo da ocasião. Fernandes et al. (2005) reforçam que o compartilhamento de sentimentos e de reações, a partir de um relacionamento que favoreça a discussão e a exploração de ideias constitui uma forma poderosa de terapia para o câncer de mama.

Assim, no espaço oferecido no MUCAMA, as mulheres encontram oportunidade para extravasar alegria ou sofrimentos juntas, encontrando ânimo para suas vidas e segurança, respeitando-se mutuamente. Desse modo, podem ajudar e ser ajudadas:

"Eu sinto assim sabe, que também tenho um papel, por isso procuro ajudar também que vem precisando de ajuda, a gente conversa com as colegas e dá força pra elas também” E1

"Eu gosto de ajudar quem chega, sei que não é fácil porque passei por isso" E3

O ato de ajudar, esclarecer, informar aquelas mulheres que ainda irão se submeter ao tratamento, provavelmente, diminuirá a expectativa e as tensões oriundas do próprio desconhecimento (PINHEIRO et al., 2008).

Fabbro, Montrone e Santos (2008) afirmam que a vivência do câncer de mama e seus tratamentos é dolorosa e causa ansiedade e medo, especialmente para aquelas que ainda estão nas fases iniciais do tratamento. Contudo, a oportunidade de dialogar com outras mulheres possibilita que elas conheçam as experiências de outras e suas estratégias para enfrentar os eventos adversos. Em nosso estudo, esse benefício de serem ajudadas por quem enfrentou a mesma situação também foi apontado pelas mulheres, o que fica claro no relato de uma participante ao ouvir a preocupação da colega, que fala:

"Quando eu cheguei ao grupo, eu só pensava nas sessões de quimioterapia que eu tinha que fazer, porque tenho pressão alta e ficava com medo dela subir e ser perigoso demais” E4

E comenta:

"Se essa é sua preocupação, pode ficar tranquila porque eu também tenho pressão alta, mas ela sobe, mas depois estabiliza e o pessoal lá da quimio monitora a gente” E2 
Pinheiro et al. (2008), que trabalharam com grupos de mulheres mastectomizadas, esclarecem que as mulheres reconhecem a importância das atividades grupais, e que cada uma delas utiliza diferentes formas de superação, além da liberdade de expressão, uma vez que o ambiente criado no grupo estimula as mulheres a exporem o que pensam, desejam e sentem.

A percepção de um ambiente psicológico propício ao acolhimento, à humanização e ao respeito ao outro também foi identificado no presente estudo:

"Aqui você não tem constrangimento em falar sobre o seu problema, todas estão ali a te ouvir e dar apoio” E8

"É muito bom estar aqui, você desabafa, sempre tem alguém para lhe escutar” E4

Assim, a participação no grupo leva as mulheres a adquirir habilidades para enfrentar as dificuldades relacionadas ao câncer e para expor seus problemas, estimulando-as a modificar atitudes e reações, além de favorecer o conhecimento de si (PINHEIRO et al., 2008).

Em relação à descontração, as mulheres revelaram que:

"Venho à tarde pra cá, a gente conversa muito, joga muita conversa fora e isso é muito bom, faz muito bem pra gente. É uma diversão” E4.

E, ainda, o diálogo entre elas configura-se como forma de lazer e de passar o tempo, reforçando a ideia de que o grupo é percebido como espaço de prazer, de encontros e de reencontros que favorecem o bem-estar geral de cada uma delas (FERNANDES at al., 2005). É nesse convívio que o espaço físico dos grupos de reabilitação se transforma em um locus social destinado a possibilitar que cada uma delas procure se ocupar consigo mesmas, fazendo com que o prazer ocupe posições cada vez mais centrais em seus espaços de vida.

Assim, fazer do grupo um espaço de interação e amizade é um benefício altamente percebido e valorizado pelas mulheres:

"Às vezes, a gente vem aqui é para passear mesmo, para encontrar com as amigas” E5

"Aqui a gente ri muito, são momentos prazerosos e quando temos que falar das nossas dores ou das outras, uma ajuda a outra” E7

Os aspectos positivos da inserção no MUCAMA também foram definidos por elas como sendo um espaço de entretenimento e lazer. Muitas enfatizam que o tempo que passam no grupo é um dos poucos momentos de suas vidas em que se sentem bem e se divertem. Vale 
ressaltar que a maioria não dispõe de condições socioeconômicas que favoreçam qualquer tipo de lazer. Assim, ocorreram mudanças em suas atividades, ampliaram e enriqueceram os seus espaços de vida com elementos positivos para a qualidade de seu viver.

"Eu gosto muito de vir pra cá. Saio de casa, me distraio, sinto como se estivesse indo para um passeio" E7

"É muito divertido, veja quando tem as nossas festinhas é muito legal. O amigo oculto mesmo eu quase nunca havia brincado fora daqui” E3

O lazer, configurado como atividade que visa ao divertimento, ao entretenimento e à distração, foi destacado como elemento de grande importância e repercussão nas vidas das mulheres, agindo como poderoso recurso terapêutico. Desse modo, o lazer é apontado como uma forma de buscar a cura da doença, visto que, como comentam Pinheiro et al. (2008) ao se distrair, a mente é ocupada de forma prazerosa, afastando os pensamentos persistentes e negativos quanto à doença.

As mulheres relataram, ainda, que o MUCAMA é um grupo que não tem o foco somente sobre a doença, mas sobre a pessoa que é acometida por ela, e tem também um poder acolhedor, curativo e tranquilizador. Sendo assim, externam sua satisfação, afirmando que não querem ter alta, pois, comparecendo ao serviço, elas amenizam muito mais que as dores ou desconfortos físicos, mas também encontram alento para suas angústias:

"Aqui a gente se sente acolhida porque você vê que, tanto os profissionais como as colegas, não estão preocupados somente com a sua doença, mas também com você, de como você está” E4

"Pra mim, tudo o que vocês fazem aqui é ótimo, a gente só tem a agradecer porque se sente bem, se sente acolhida” E5

Portanto, as intervenções psicossociais empreendidas no grupo são apontadas como benéficas pelas participantes do estudo, o que as estimula a permanecer no grupo de reabilitação. Esses achados são semelhantes a um estudo desenvolvido em um núcleo de reabilitação de mastectomizadas, conduzido por Almeida (2006), o qual revelou que as intervenções físicas e psicossociais parecem obter resultados satisfatórios, uma vez que lá o retorno das mulheres é livre e, mesmo assim, o comparecimento das mesmas é crescente e assíduo.

Pesquisas mostram que a satisfação do paciente, revelada por meio de seu comportamento em saúde, em relação a cuidados com sua recuperação após um agravo já instalado, é determinada pela interação entre suas expectativas, ou seja, suas crenças sobre a 
doença, sua gravidade e as características do cuidado recebido. Essas características incluem itens relacionados à acessibilidade dos serviços, aos custos, à natureza das instalações e dos cuidados recebidos, bem como a sua continuidade (FRANCO, 2011; OMAR; CHIFFMAN; BINGHAM, 2001).

Acreditamos que o conjunto dessas características, também identificadas pelas participantes desse estudo, quanto às orientações e atividades fornecidas no grupo influenciaram sobremaneira para a adesão a comportamentos e a atitudes positivas para a reabilitação.

Portanto, corroboramos com Rodrigues, Silva e Fernandes (2003) com a ideia de que os grupos de reabilitação, nesse contexto, são considerados elementos relevantes e necessários para o processo de recuperação da mulher e de aceitação do câncer de mama e da mastectomia, possibilitando o compartilhar de experiências de vida a respeito da convivência com a enfermidade e a procura coletiva de meios de resolução para os seus problemas, além de se constituírem em um local de prazer e descontração.

Nessa categoria, as mulheres ainda demonstraram perceber os benefícios de sua participação no grupo de reabilitação, ao afirmar a importância do atendimento gratuito e especializado, conforme observamos nas falas a seguir:

\footnotetext{
"Eu gosto muito do atendimento, pois além de a gente ser tratada por quem sabe (especialistas), ainda é de graça, porque se fosse pra pagar a gente não teria condição” E1

“É muito bom a gente ter um serviço deste aqui na cidade porque antes só pra fazer a quimio a gente tinha que ir lá em Varginha (município vizinho) o que cansava e desgastava muito a gente” E2
}

O acesso aos serviços de saúde e a possibilidade de atendimento específico para suas necessidades ainda é um obstáculo para o controle efetivo e para a detecção precoce do câncer de mama em nosso país. Pinho et al. (2007) recomendam que o tratamento desse câncer seja abordado por uma equipe multidisciplinar, sendo realizado de uma forma integral e em conjunto para fornecer melhores subsídios de recuperação às pacientes.

Sabemos que são poucos os programas de reabilitação disponíveis para mulheres submetidas à cirurgia por neoplasia maligna de mama, além de serem restritos, em geral, a centros especializados. E, infelizmente, há razões que inviabilizam o acesso de muitas mulheres a esses centros no Brasil, como a dificuldade de locomoção por motivos financeiros ou até mesmo de ordem operacional, por ser a localização desses centros, geralmente, concentrada apenas nas grandes cidades, como afirmam Amaral et al.( 2005). 
Assim, os grupos de reabilitação emanaram como uma possibilidade de atender às demandas das mulheres mastectomizadas e suprir a carência de serviços especializados que atendam à demanda dessa clientela. Por isso, autores como Pereira et al. (2006) e Silva e Santos (2008) afirmam a necessidade de criação de mais espaços de reabilitação integral permanente.

À luz do MCS, a explicação de tais transformações que culminam em atitudes positivas em relação à saúde e à vida está na dependência de duas classes de variáveis: o estado psicológico da pessoa para a tomada de ação específica àquela condição de saúde ou de vida e a sua percepção sobre o potencial daquela ação para a redução de ameaças à sua saúde e ao seu bem-estar. Cabe complementar ainda que, segundo a perspectiva da existência de um campo psicológico, a consciência de uma diferenciação das várias dimensões do espaço de vida é uma condição relevante para aumentar a percepção sobre as dimensões de realidade e de irrealidade (LESCURA; MAMEDE, 1990).

Portanto, na análise das falas das mulheres, apreende-se que elas, ao participar do grupo especializado em reabilitação, transcenderam o nível de irrealidade de um passado psicológico, ocasião em que identificavam diversos desejos e medos do futuro, para um nível de realidade do futuro psicológico que para elas corresponde às esperanças e às expectativas positivas de um projeto de vida condizente com sua condição existencial.

\subsubsection{Percepção das dificuldades para participar do grupo e/ou aderir às atividades propostas}

O indivíduo pode acreditar na eficácia de uma determinada ação em reduzir a ameaça da doença e, ao mesmo tempo, perceber essa ação como inconveniente, dispendiosa, dolorosa, desconfortável ou que consuma muito tempo. Esses aspectos negativos das ações de saúde ou de percepção de barreiras podem agir como impedimentos para a adoção dos comportamentos recomendados e podem gerar conflitos na tomada de decisão (ROSENSTOCK, 1974, 1990).

$\mathrm{Na}$ presente pesquisa, as mulheres colaboradoras identificaram barreiras para participação no grupo de reabilitação e de adesão às atividades e às orientações fornecidas.

Desse modo, ao serem questionadas sobre o que achavam das rotinas do serviço, as mulheres afirmaram a respeito do horário de funcionamento: 
"Eu gosto do horário, porque se fosse muito cedinho ou na volta do dia, ficava difícil deu vir porque, às vezes, a gente tem outros compromissos e as coisas de casa pra cuidar, mas se tivessem mais horários, seria muito bom” E1

"Para mim, o horário é bom, mas se tivessem outros, daí dava pra gente ter mais opção. Mas, mesmo assim, eu esforço e compareço no dia que tem o atendimento porque sei que é o melhor dia e horário para a maioria” E5

O propósito de um grupo, como comentam Pinheiro et al. (2010), é atingir a meta ou os objetivos que motivaram a sua formação. Para que isso seja alcançado, é necessário que o grupo também desenvolva relacionamento e estruturas que apoiem o alcance de seus objetivos. Os relacionamentos entre os membros do grupo se caracterizam por elevado grau de confiança e apoio, numa interação em que são livres para opinar sem temer críticas ou rejeições (ZIMMERMAN, 2000).

Assim, as mulheres desenvolveram uma relação tal que procuraram estar de acordo com as estruturas que compõem o processo de trabalho do grupo. Essas composições incluem as normas de funcionamento, como os dias, os horários e a estrutura do local.

Portanto, para a maioria delas, o horário de atendimento é favorável, principalmente, devido ao fato de já estarem dispensadas dos principais afazeres domésticos, como cozinhar e direcionar os membros da família para suas atividades, porém expressam que poderia haver mais dias e horários de atendimentos, para diversificar e facilitar o comparecimento:

“O horário não é ruim não, pena que seja somente uma vez na semana, a gente queria mais (risos)” E3

"Como aqui é longe da minha casa, eu prefiro mesmo que seja à tarde, mas se a gente falta por algum motivo, daí é só na outra semana, porque só tem atendimento na quinta-feira” E4

"Eu não acho o horário ruim, mas é uma pena que é uma única vez na semana” E7

Assim, ressaltamos a necessidade de documentar os trabalhos do serviço de reabilitação para angariar subsídios para solicitar apoio institucional e almejarmos uma ampliação do trabalho do mesmo. As demandas do serviço também se fazem presentes quando as mulheres relatam a necessidade de um maior espaço físico para comportar todas as participantes e conferir maior dinamismo às atividades, conforme fica exposto nas falas que se seguem:

"Eu gosto do número de pessoas, aqui a gente não se sente só, sente que estamos todas no mesmo barco, porém, às vezes fica meio difícil fazermos todas as atividades por causa do espaço” E7 
"É bom o número de pessoas, uma ajuda a outra, às vezes a sua dúvida é a mesma da colega e tem também muita gente pra esclarecer as coisas pra gente, mas quando tem mais gente, às vezes fica um pouco apertado” E8

Esses achados também foram encontrados por Franco (2011), ao estudar a importância de um grupo de reabilitação para as mulheres que o frequentam.

As colaboradoras do estudo afirmaram, ao manifestar críticas e sugestões, que consideravam insuficiente o espaço físico oferecido pelo serviço, por causa do número crescente de participantes. Assim, afirmamos que, apesar de o comparecimento ser assíduo e de as mulheres identificarem mais benefícios que barreiras para aderir às atividades empreendidas no grupo, são necessárias adaptações para o atendimento eficaz e satisfatório às necessidades das mesmas, fornecendo maiores subsídios que as motivem para a tomada de ação em participar do serviço de reabilitação.

Quando questionamos as mulheres entrevistadas sobre a regularidade de sua participação no grupo e quais seriam os motivos de ausências, elas reconheceram como principal barreira a necessidade de fazer o tempo e a disposição:

“Às vezes, a gente falta porque fica desanimada, falta mais força de vontade, eu acho” E6

“Tem dias que eu não venho porque, pra falar a verdade, eu desanimo de vir de casa até aqui, mas depois que a gente falta, a gente vê que era melhor ter vindo, sente a necessidade” E4

As mulheres justificaram que é necessário ter disposição para aderir às atividades empreendidas no grupo e participar regularmente. Esses resultados estão de acordo com os de Prado et al. (2004) que, em seu estudo, ressaltaram a necessidade de as mulheres mastectomizadas dedicarem um tempo para si mesmas e que, caso contrário, com a incorporação de novas atividades em seus cotidianos, ficariam prejudicadas.

As participantes deste estudo reforçaram que procuram vencer o desânimo e manter-se assíduas no grupo participando das atividades, pois, para elas, a percepção de melhora de sua condição de saúde, resultado da noção de suscetibilidade e de seriedade da doença, só é alcançada quando promovem mudanças comportamentais:

“Ah, eu esqueço o desânimo, costumo dizer que eu não perco por nada, eu já deixo avisado em casa que na quinta à tarde largo tudo e tenho que sair” E7

"A gente tem consciência que se deixarmos o desânimo vencer é pior pra saúde da gente, por isso a gente esforça e vem pra cá” E1 
Portanto, percebemos, ao analisar as respostas das entrevistadas que o conhecimento e percepção a respeito das repercussões da adesão às atividades e às orientações fornecidas no grupo de reabilitação para a sua saúde são identificadas como positivas e benéficas para as mulheres. Prado et al. (2004) reforçam que isso se deve ao fato de elas reconhecerem que a adesão às atividades era condição para obterem maior disposição corporal, fortalecimento dos músculos, boa movimentação do membro homolateral à cirurgia, além de favorecer o sono, prevenir o estresse e ajudar na saúde mental.

Outro fator considerado relevante pelas mulheres para dificultar a adesão ao programa do grupo de reabilitação é o compromisso com os afazeres domésticos, conforme demonstrado pelas falas que se seguem:

“A gente já melhorou muito esta parte que eu vou te falar, mas tem dias que a gente distrai tanto com os afazeres de casa que quando vê já perdeu a hora de ir pro grupo" E6

"Tem dia que eu trabalho tanto em casa que quando vejo estou cansada e desanimo de ir ao grupo" E4

"Se eu tenho muito serviço em casa, tem dias que não dá para comparecer” E5

O compromisso das mulheres com as atividades do lar é um fator determinante para a realização ou não de qualquer atividade complementar. Essa dificuldade é reflexo do papel de cuidadoras historicamente construído ao gênero feminino. Conforme reforçam Ambrósio (2010) e Caetano, Gradim e Santos (2009), mesmo nos dias atuais, devido a um forte componente cultural, as mulheres têm dificuldades em priorizar outras atividades que não sejam as domésticas e ligadas ao cuidado com o lar.

Assim, as orientações empreendidas no grupo de reabilitação podem ser um ponto chave para que as mulheres reconheçam a importância da adesão às atividades e se esforcem para a promoção de mudanças comportamentais e estilos de vida, transformando em valências positivas o cuidado consigo próprias, mobilizando-o para posições centrais de seus espaços de vida. 
Síntese dos resultados do estudo e Considerações finais 


\section{SÍNTESE DOS RESULTADOS DO ESTUDO E CONSIDERAÇÕES FINAIS}

O quadro abaixo sintetiza os resultados do estudo.

Quadro 3: Modelo de Crenças em Saúde como determinante do comportamento em saúde aplicado a mulheres integrantes de um grupo de reabilitação.

PERCEPÇÕES INDIVIDUAIS

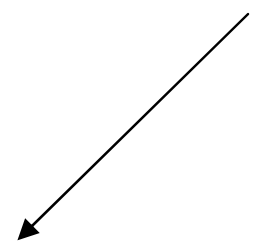

- $\quad$ Suscetibilidade percebida para o câncer de mama: doença democrática; aspectos culturais da doença (doença de caráter punitivo); falta de conhecimento sobre a doença.

- $\quad$ Seriedade percebida do câncer de mama: perplexidade diante do diagnóstico; medo do desfiguramento e da finitude da vida; preconceitos, traumas advindos da perda da mama e dos outros tratamentos; interferência com papéis sociais da mulher.

FATORES MODIFICADORES

PROBABILIDADE DE AÇÃo

- Variáveis sócio psicológicas: traços de personalidade; educação de base familiar; falta de cuidado com o corpo e do exercício da sexualidade.

- Variáveis sociais: crenças sobre os fatores de risco da doença. Novos conhecimentos sobre a doença e seus tratamentos adquiridos ao longo dos tratamentos. Crença na esperança da cura pela fé, família e apoio social.

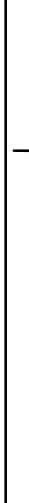
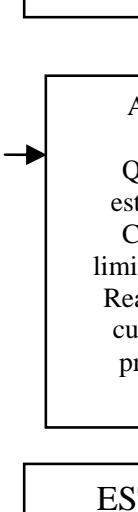

AMEAÇA PERCEBIDA DO CÂNCER DE MAMA: Questionamentos existenciais, estigma, reorganização familiar; Complicações da doença (dor, limitação de movimentos, recidiva) Realização correta do tratamento, cuidado com o corpo, a mente e prática da prevenção (diminuir ameaça)

ESTÍMULOS PARA AÇÃO

- Conselhos de familiares e amigos;

- Encaminhamentos médicos e da rede de apoio social;

- Doença de um membro da família;

- Recomendações dos profissionais de saúde;

- Crença no papel da equipe (atendimento especializado).
- Benefícios percebidos: melhora no desempenho físico com possibilidade de retorno às atividades cotidianas; esclarecimentos de dúvidas; compartilhamento de experiências, liberdade de expressão; descontração; atendimento gratuito e especializado.

- Barreiras percebidas: dias e horários de atendimento limitados; afazeres domésticos; necessidade de demandar tempo e disposição; melhora da estrutura física do serviço.

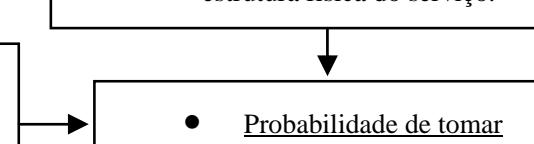
medidas de ações preventivas em saúde (obtenção de informações e aprendizado sobre a doença e a reabilitação com resultante mudança de hábitos de vida). 
As percepções individuais das entrevistadas acerca do câncer de mama foram influenciadas pelas suas crenças sobre suscetibilidade e seriedade ao longo de suas experiências com a doença e seus tratamentos, o que as levou a um comportamento em saúde de participarem do grupo de reabilitação porque o consideraram um meio para cuidarem da saúde.

O comportamento das mulheres atingiu um caráter dinâmico, ou seja, o presente psicológico das mesmas foi influenciado por suas crenças advindas do passado psicológico e de expectativas do futuro psicológico. Esse comportamento demonstrou forte componente motivacional determinado por fatores modificadores, nos quais as variáveis sociais (conhecimento sobre a doença, contato anterior com a mesma, dentre outros) foram as prevalentes.

As percepções de seriedade da doença e suscetibilidade a ela sofreram um dinamismo acentuado na medida em que as mulheres enfrentaram as várias etapas do processo de serem portadoras do câncer de mama. Elas perceberam várias ameaças, não apenas à sua integridade física, como, por exemplo, a perda da mama, mas também outras de natureza social, como o estigma do câncer na sociedade, e familiar, como a necessidade de reorganização na estrutura do lar.

Os estímulos para a ação que reduziram a ameaça percebida da doença e aumentaram a probabilidade de tomar medidas de ações no cuidado em saúde em participarem do grupo de reabilitação foram os encaminhamentos ao serviço por membros da rede de saúde e social, como os médicos e a Associação Vida Viva; conselhos da família e as recomendações e o vínculo com os profissionais de saúde do grupo, bem como a experiência da doença em algum membro da família.

A prática da ação em participarem do grupo de reabilitação se concretizou no momento em que vislumbraram maiores benefícios (melhora da disposição física, reabilitação psicossocial) que as barreiras percebidas (disposição e disponibilidade de tempo; rotinas e estrutura do serviço).

Assim, as mulheres, conscientes dos benefícios, comparecem ao serviço tanto por causa da prática de exercícios e de sua reabilitação física, quanto por causa do vínculo estabelecido com os profissionais de saúde e com as demais mulheres participantes do grupo, por considerarem o local como um espaço de troca de experiências e lúdico. O grupo propiciou o fortalecimento físico, mental e psicossocial de suas participantes, que o consideraram como um espaço em que são ajudadas e podem oferecer ajuda. 
Ficou evidente a importância da busca de interrelações dessas dimensões conceituais do MCS que são indispensáveis para fundamentar o planejamento da Educação em Saúde na prática de enfermagem, nesse caso, especificamente, na atuação no grupo de reabilitação.

Assim, por meio da educação em saúde, o grupo de reabilitação pode funcionar como um local de acesso a informações. A inserção de mulheres mastectomizadas nesses espaços pode proporcionar-lhes um suporte que muitas vezes não recebem em outros tipos de serviços, cabendo aos profissionais que as atendem, especialmente aos de enfermagem, assegurar-lhes uma boa compreensão acerca da doença, do tratamento a ser seguido, dos procedimentos e efeitos colaterais.

Para se obter resultados satisfatórios em grupos, é importante atentar-se para a utilização de uma linguagem única e familiar. Nesse sentido, a receptividade, o estímulo e o apoio dos organizadores contribuíram para o crescimento pessoal das mulheres integrantes do grupo, ressaltando suas potencialidades para a superação das limitações.

O processo de reabilitação é facilitado pelos grupos, na medida em que têm a possibilidade de incorporar os recursos de outros serviços ao processo terapêutico adotado para o plano de cuidados da mulher. Assim, os parâmetros de sucesso na assistência à mulher mastectomizada não se relacionam apenas aos cuidados restritos ao controle da doença, à movimentação do braço e ombros e à redução do linfedema, mas também àqueles de ajustamento à sua nova imagem corporal, à sua nova condição de saúde, à satisfação no relacionamento familiar e social, dentre outros.

Compreendemos, desse modo, que se deve avaliar a qualidade dos serviços de reabilitação sob a ótica das usuárias para estabelecer metas e definir prioridades, enfocando a reabilitação integral, sendo necessária a criação de novos espaços e equipes multiprofissionais, considerando-se a complexidade da atenção ao paciente oncológico. 
Referências 


\section{REFERÊNCIAS}

ALMEIDA, A. M. A reabilitação de mulheres com câncer de mama: uma análise descritiva no Núcleo de Ensino, Pesquisa e Extensão na Reabilitação de Mastectomizadas. 2006. 104 f. Tese (Livre docência) - Escola de Enfermagem de Ribeirão Preto, Universidade de São Paulo, Ribeirão Preto, 2006.

ALMEIDA, A. M.; MAMEDE, M. V.; PANOBIANCO, M. S.; PRADO, M. A. S.; CLAPIS, M. J. Construindo o significado da recorrência da doença: a experiência de mulheres com câncer de mama. Revista Latino Americana de Enfermagem, Ribeirão Preto, v. 9, n. 5, p 63-69, 2001.

AMARAL, M. T. P. do.; TEIXEIRA, L. C.; DERCHAIN, S. F. M.; NOGUEIRA, M. D.; PINTO e SILVA, M. P.; GONÇALVES, A. V. Orientação domiciliar: proposta de reabilitação física para mulheres submetidas À cirurgia por câncer de mama. Revista de Ciências Médicas, Campinas, v. 14, n. 5, p. 405-13, 2005.

AMBRÓSIO, D. M. Mulheres com câncer de mama: a vivência do apoio social e familiar durante o tratamento. 2010. 185 f. Dissertação (Mestrado) - Faculdade de Filosofia, Ciência e Letras de Ribeirão Preto, Universidade de São Paulo. Ribeirão Preto, Ribeirão Preto, 2010.

BARBOSA, R. C. M; XIMENES, L. B.; PINHEIRO, A. K. B. Mulher mastectomizada: desempenho de papéis e redes sociais de apoio. Acta Paulista de Enfermagem, São Paulo, v. 17, n. 1, p. 18-24, 2004.

BARDIN, L. Análise de conteúdo. Rio de Janeiro: Edições 70, 2004.

BARROS, A. de J. P. de; LEHFELD, N. A. S. Projeto de Pesquisa: propostas metodológicas. 16 ed. Petrópolis: Vozes, 2005.

BERGAMASCO, R. B.; ÂNGELO, M. O sofrimento de descobrir-se com câncer de mama: como o diagnóstico é experienciado pela mulher. Revista Brasileira de Cancerologia, Rio de Janeiro, v. 47, n. 3, p. 277-82, 2001.

BIFFI, R. G.; MAMEDE, M. V. Dinâmica familiar: percepção de famílias de sobreviventes de câncer de mama. Escola Anna Nery. Revista de Enfermagem, Rio de Janeiro, v. 13, n. 1, p. 131-139, 2009.

BIFFI, R. G.; MAMEDE, M. V. Perception of Family Functioning Among Relatives of Women Who Survived Breast Cancer: Gender Differences. Revista Latino Americana de Enfermagem, Ribeirão Preto, v. 18, n. 2, p. 269-277, 2010 
BITTENCOURT, J. F. V.; CADETE, M. M. M. Vivências da mulher a ser mastectomizada: Esclarecimentos e orientações. Revista Brasileira de Enfermagem, Brasília, v. 55, n. 4, p. 420-423, 2002.

BRASIL, CNS - Conselho Nacional de Saúde. Ministério da Saúde. Resolução nº 196/1996. Fixa diretrizes e normas regulamentadoras para a pesquisa envolvendo seres humanos. Brasília, 1996. Disponível em: http://conselho.saude.gov.br/resolucoes/reso_96.htm. Acesso em: 29 de set. 2010.

BRASIL, INCA - Instituto Nacional de Câncer. Ministério da Saúde. Ações de Enfermagem para o controle do câncer: uma proposta de integração ensino-serviço. $3^{\text {a }}$ Ed. Rio de Janeiro: INCA, 2008.

INCA - Instituto Nacional de Câncer. Ministério da Saúde. Câncer de Mama. Rio de Janeiro: INCA, 2011a. Disponível em: http://www2.inca.gov.br/wps/wcm/connect/ tiposdecancer/site/home/mama. Acesso em: 20 de set. 2011.

INCA - Instituto Nacional de Câncer. Ministério da Saúde. Controle do Câncer de Mama: Documento de Consenso. Rio de Janeiro: INCA, 2004. 39p.

INCA - Instituto Nacional de Câncer. Ministério da Saúde. Estimativa 2012: incidência de câncer no Brasil. Rio de Janeiro: INCA, 2012. Disponível em: http://www1. inca.gov.br/estimativa/2012/. Acesso em: 23 jan. 2012.

INCA - Instituto Nacional de Câncer. Ministério da Saúde. Programa Nacional de Controle do Câncer de Mama. Rio de Janeiro: INCA, 2011b. 15p. Disponível em: http://www2.inca.gov.br/wps/wcm/connect/acoes_programas/site/home/nobrasil/programa_co ntrole_cancer_mama/. Acesso em 30 de out. 2011.

INCA - Instituto Nacional de Câncer. Ministério da Saúde. Sumário Executivo. Políticas e Ações para Prevenção do Câncer no Brasil. Alimentos, Nutrição e Atividade Física. Rio de Janeiro: INCA, 2009. 16 p.

BRASIL. Ministério da Saúde. Secretaria Executiva. Departamento de Apoio à Descentralização. Coordenação-Geral de Apoio à Gestão Descentralizada. Diretrizes operacionais dos Pactos pela Vida, em Defesa do SUS e de Gestão. Brasília, 2006. 76p.

CAETANO, E. A.; GRADIM, C. V. C.; SANTOS, L. E. S. Câncer de mama: reações e enfrentamento ao receber diagnóstico. Revista Enfermagem UERJ, Rio de Janeiro, v. 17, n. 2, p. 257-61, 2009.

CANTINELLI, F. S.; CAMACHO, R. S.; SMALETZ, O.; GONSALES, B. K.; BRAGUITTONI, E.; RENNÓ JR, J. A. oncopsiquiatria no câncer de mama: considerações a respeito de questões do feminino. Revista de Psiquiatria Clínica, São Paulo, v. 33, n.3, p. 124-133, 2005. 
CHO O. H.; YOO, Y. S.; KIM, N. C. Efficacy of comprehensive group rehabilitation for women with early breast cancer in South Korea. Nursing and Health Sciences, Carlton, v. 8, n.3, p. 140-146, 2006.

COUTO, A. J. O modelo de crenças na saúde e a Teoria do comportamento planeado na educação para a saúde. Revista Referência, Coimbra, v. 1, p. 5-9, 1998.

DALEY, A. J .; CRANK, H.; MUTRIE, N.; SAXTON, J. M.; COLEMAN, R. Determinants of adherence to exercise in women treated of breast cancer. European Journal of Oncology Nursing, Edinburgh, v. 11, n. 5, p. 392-9, 2007.

DELA COLETA, M. F. O Modelo de Crenças em Saúde. In: DELA COLETA, M. F. e cols. Modelos para pesquisa e modificação de comportamentos de saúde: teorias, estudos e instrumentos. Taubaté: Cabral Editora e Livraria Universitária, 2004.

DeLISA, J.A. A history of cancer rehabilitation. Cancer. Supplement: Cancer Rehabilitation in the New Millennium, Philadelphia, v.92, n.4, p. 970-4. 2001.

DUARTE, T. P.; ANDRADE, N. A. Enfrentando a mastectomia: análise do relato de mulheres mastectomizadas sobre questões ligadas à sexualidade. Estudos de Psicologia, Natal, v.8, n.1, p. 155-163, 2003.

EDELMAN, S., CRAIG, A., KIDMAN, A. D. Group intervention with cancer patients: efficacy of psychoeducational versus supportive groups. Journal of Psychosocial Oncology, New York, v. 18, n. 3, p. 67-85, 2000.

FABBRO, M. R. C.; MONTRONE, A. V. G.; SANTOS, S. Percepções, conhecimentos e vivências de mulheres com câncer de mama. Revista Enfermagem UERJ, Rio de Janeiro, v. 16, n. 04, p. 532-7, 2008.

FERNANDES, A. F. C.; CAVALCANTI, P. P.; BONFIM, I. M.; MELO, E. M. M. Significado do grupo de autoajuda na reabilitação da mulher mastectomizada. Revista Mineira de Enfermagem, Belo Horizonte, v.9, n.1, p.47-51, 2005.

FERNANDES, A. F. C.; MAMEDE, M. V. O surgimento do câncer de mama na visão de um grupo de mulheres mastectomizadas. Texto \& Contexto Enfermagem, Florianópolis, v. 13, n. 01, p. 35 - 40, 2004.

FERNANDES, A. F. C.; RODRIGUES, M. S. P.; CAVALCANTI, P. P. Comportamento da mulher frente às atividades grupais. Revista Brasileira de Enfermagem, Brasília, v. 57, n. 1, p. 31-4, 2004. 
FOLGUEIRA, M. A. K.; BRENTANI, M. M. Receptores de estrógeno e progesterona em câncer de mama. In: BRENTANI, M. M.; COELHO, G. C.; KOWALSKI, L. P. Bases da Oncologia. 2 Ed. São Paulo: Lemar, 2003, cap. 9, p. 147-166.

FRANCO, A. H. J. A experiência de participar de um grupo de reabilitação integral para mastectomizadas. 2011. 96 f. Dissertação (Mestrado) - Escola de Enfermagem de Ribeirão Preto, Universidade de São Paulo, Ribeirão Preto, 2011.

FUGITA, R. M. I.; GUALDA, D. M. R. A causalidade do câncer de mama à luz do Modelo de Crenças em Saúde. Revista da Escola de Enfermagem da USP, São Paulo, v. 40, n. 4, p. 501-6, 2006.

GATTI, B. A. Grupo focal na pesquisa em ciências sociais e humanas. Brasília: Liber Livro, 2005, 75 p.

GERBER, L. H. Cancer rehabilitation into the future. Cancer. Supplement: Cancer Rehabilitation in the New Millennium, Philadelphia, v.92, n. 4, p. 975-9, 2001.

GOMES, F. A.; PANOBIANCO, M. S.; FERREIRA, C. B.; KEBBE, L. M.; MEIRELLES, M. C. C. Utilização de grupos na reabilitação de mulheres com câncer de mama. Revista Enfermagem UERJ, Rio de Janeiro, v. 11, n. 3, p. 292-5, 2003.

GOTTLIEB, B. H.; WACHALA, E. D. Cancer support groups: a critical review of empirical studies. Psycho-Oncology, Chichester, v. 16, n. 5, p. 370-400, 2007.

GRADIM, C. V. C. Sexualidade de casais que vivenciaram o câncer de mama. 2005. 182 f. Tese (Doutorado) - Escola de Enfermagem de Ribeirão Preto, Universidade de São Paulo, Ribeirão Preto, 2005.

GUIRRO, R. Fisioterapia dermato-funcional: fundamentos, recursos, patologias. 3 ed. São Paulo: Manole, 2002.

GUTIÉRREZ, M. G. R.; BRAVO, M. M.; CHANES, D. C.; De VIVO, M. C. R.; SOUZA, G. O. de. Adesão de mulheres mastectomizadas ao início precoce de um programa de reabilitação. Acta Paulista de Enfermagem, São Paulo, v. 20, n.3, p. 249-57, 2007.

HOFFMANN, F. S.; MULLER, M. C.; FRASSON, A. L. Repercussões psicossociais, apoio familiar e bem-estar espiritual em mulheres com câncer de mama. Psicologia, Saúde \& Doença, Lisboa, v. 7, n. 2, p. 239-254, 2006.

JANZ, N. K.; BECKER, M. H. The health belief model: a decade later. Health Education Quarterly, New York, v. 11, n.1, p. 1-47, 1984. 
JUÁREZ, G. M. R. Reabilitação em Oncologia: análise de conceito. 2003. 115f. Dissertação (Mestrado) - Escola de Enfermagem de Ribeirão Preto, Universidade de São Paulo, Ribeirão Preto, 2003.

KIND, L. Notas para o trabalho com a técnica de grupos focais. Psicologia em Revista, Belo Horizonte, v. 10, n. 15, p. 124-136, 2004.

KÓVACS, M. J. Bioética nas questões da vida e da morte. Psicologia USP, São Paulo, v. 14, n. 2, p. 115-16, 2003.

LESCURA, Y.; MAMEDE, M. V. Educação em Saúde: abordagem para o enfermeiro. São Paulo: Sarvier, 1990.

LEVORLINO, A. S.; PELICIONI, M. C. F. A utilização do grupo focal cmo metodologia qualitativa na promoção da saúde. Revista da Escola de Enfermagem da USP, São Paulo, v. 35, n. 2, p. 115-21, 2001.

LEWIN, K. Teoria de Campo em Ciência Social. Tradução: C. M. BORI. São Paulo: Pioneira, 1965.

MAIMAN, L. A.; BECKER, M. H. The health belief model: origins and correlates in psychological theory. Health Education Monographs, New York, v. 2, n. 4, p. 336-353, 1974.

MELCHIOR, F. O. Efeitos da ginástica postural global do método Isostretching na recuperação dos movimentos de flexão e abdução do braço homolateral à cirurgia de mulheres tratadas de câncer de mama. 2007. 81 f. Dissertação (Mestrado) - Escola de Enfermagem de Ribeirão Preto - Universidade de São Paulo, Ribeirão Preto, 2007.

MINAYO, M. C. S. Pesquisa social: teoria, método e criatividade. 26 ed. Petrópolis: Vozes, 2007, p. 79-108.

MORGAN, D. L. Focus group as qualitative research. 2 ed. London (UK): Sage University Paper; 1997.

OLIVEIRA, M. S.; SOUZA, A. M. A.; FERNANDES, A. F. C. Grupo apoyo/soporte: espacio de rehabilitación para mujeres mastectomizadas. Revista Eletrônica de Enfermagem, Goiânia, v. 10, n. 3, p. 16-22, 2008 [Internet]. Disponível em: http://www.fen.ufg.br/revista/ v10/n3/v10n3a27.htm. Acesso em 09 de agosto de 2011.

OMAR, M. A.; SHIFFMAN, R. F.; BINGHAN, C. R. Development and testing of the patient expectations and satisfaction with prenatal care instrument. Research in Nursing \& Health, New York, v. 24, p. 218-229, 2001. 
OPAS - Organização Pan-Americana da Saúde. Doenças crônico-degenerativas e obesidade: estratégia mundial sobre alimentação saudável, atividade física e saúde. Brasília: OMS - Organização Mundial de Saúde, 2003. p. 35-42.

OTAKE, A. H.; CHAMMAS, R.; ZATZ, R. Novos alvos na luta contra o câncer. Revista Ciência Hoje (SBPC). v. 38, p.28-33, 2006.

PANOBIANCO, M. S.; MAMEDE, M. V.; ALMEIDA, A. M.; CLAPIS, M. J.; FERREIRA, C. B. Experiência de mulheres com linfedema pós-mastectomia: significado do sofrimento vivido. Psicologia em Estudo, Maringá, v. 13, p. 807-816, 2008.

PANOBIANCO, M. S.; MAMEDE, M. V. Complicações e intercorrências associadas ao edema de braço nos três primeiros meses pós mastectomia. Revista Latino Americana de Enfermagem, Ribeirão Preto, v. 10, n. 4, p. 544-551, 2002.

PEREIRA, S. G.; ROSENHEIN, D. P.; BULHOSA, M. S.; LUNARDI, V. L.; FILHO, W. D. L. Vivências de cuidados da mulher mastectomizada: uma pesquisa bibliográfica. Revista Brasileira de Enfermagem, Brasília, v. 59, n. 6, p. 791-5, 2006.

PETERSSON, L-M.; BERGLUND, G.; BRODIN, O.; GLIMELIUS, B.; SJODEN P-O. Group rehabilitation for cancer patients: satisfaction and perceived benefits. Patient Education and Counseling, Limerick, v.40, n. 3, p. 219-29, 2000.

PINHEIRO, C. P. O.; SILVA, R. M. da.; MAMEDE, M. V.; FERNANDES, A. F. C. Participação em grupos de apoio: experiência de mulheres com câncer de mama. Revista Latino Americana de Enfermagem, Ribeirão Preto, v.16, n.4, p. 733-38, 2008.

PINHEIRO, C. P. O.; FERNANDES, A. F. C.; MAMEDE, M. V.; SILVA, R. M. da. Redescoberta da vida: apoiando a mulher com câncer de mama. Campinas: Saberes Editora, 2010. cap. 06, 103 p.

PINHO, L. S.; CAMPOS, A. C. S.; FERNANDES, A. F. C.; LOBO, S. A. Câncer de mama: da descoberta à recorrência da doença. Revista Eletrônica de Enfermagem (on line), Goiânia, v. 9, n. 1, p. 154-165, 2007. Disponível em: http://www.fen.ufg.br/revista/v9/n1/ v9n1a12.htm. Acesso em: 25 de set. 2010.

PITA, A. M. F. Reabilitação Psicossocial no Brasil. São Paulo: HUCITEC, 1996.

POPE, C.; MAYS, N. Pesquisa qualitativa na atenção à saúde. 3 ed. Porto Alegre: Artmed, 2009.

POPIM, R. C.; BOEMER, M. B. Cuidar em Oncologia na perspectiva de Alfred Schutz. Revista Latino Americana de Enfermagem, Ribeirão Preto, v. 13, n. 5, p. 677-85, 2005. 
PRADO, M. A. S.; MAMEDE, M. V.; ALMEIDA, A. M.; CLAPIS, M. J. A prática da atividade física em mulheres submetidas a cirurgia por câncer de mama: percepção de barreiras e benefícios. Revista Latino Americana de Enfermagem, Ribeirão Preto, v. 12, n. 3, p. 494-502, 2004.

RODRIGUES, D. P.; SILVA, R. M.; FERNANDES, A. F. C. O processo adaptativo de mulheres mastectomizadas: grupo de apoio. Revista Enfermagem UERJ, Rio de Janeiro, v. 11, n. 1, p.64-9, 2003.

ROGERS, L. Q.; COURNEYA, K. S.; SHAH, P.; DUNNINGTON, G.; HOPKINS-PRICE, P. Exercise stage of change, barriers, expectations, values and preferences among breast cancer patients during treatment: a pilot study. European Journal of Cancer Care, Oxford, v. 16, n.1, p. 55-66, 2007.

ROSENSTOCK, I. M. The health belief model and preventive health behavior. Health Education Monographs, New York, v.2, n.4, p. 354-387, 1974.

The health belief model: explaining health behavior through expectancies. In:

GLANZ, K. Health behavior and health education: theory, research and practice. San Francisco: Jossey-Bass, chap. 3, p. 39-62, 1990.

SALVAJOLI, J. V.; SILVA, M. L. G. Radioterapia. In: CARVALHO, V. A.; FRANCO, M. H. P.; KOVÁCS, M. J.; LIBERATO, R. P.; MACIEIRA, R. C.; VEIT, M. T.; GOMES, M. J. B.; BARROS, L. H. de C. (Orgs.), Temas em Psico-oncologia. São Paulo: Summus, 2008, p. 150-4.

SANT’ANNA, D. V.; ALMEIDA, V.; PETITO, E. L.; GUTIÉRREZ, M. G. R. Adesão à prática de exercícios para reabilitação funcional de mulheres com câncer de mama: revisão de literatura. Ciencia y Enfermería, Concepcion, v. 16, n. 1, p. 97-104, 2010.

SANTOS, S. C. A. S. A importância e a influência da fé, da religiosidade e da espiritualidade na experiência do câncer de mama em mulheres mastectomizadas. 2008. 96 f. Dissertação (Mestrado) - Pontifícia Universidade Católica de São Paulo, São Paulo, 2008.

SEFFNER, F. A. AIDS, estigma e corpo. In: LEAL, O. (org.). Corpo e significado. Porto Alegre: Ed. Da Universidade, 1995.

SILVA, G.; SANTOS, M. A. "Será que não vai acabar nunca?”: perscrutando o universo do pós-tratamento do câncer de mama. Texto \& Contexto Enfermagem, Florianópolis, v. 17, n. 3, p. 561-568, 2008.

SILVA, L. C. da. Câncer de mama e sofrimento psicológico: aspectos relacionados ao feminino. Psicologia em Estudo, Maringá, v. 13, n. 2, p. 231-237, 2008 a. 
SILVA, M. P. P. Impacto de um programa de reabilitação em mulheres submetidas à biópsia do linfonodo sentinela ou linfadenectomia axilar por câncer de mama inicial. 2008. 100f. Tese (Doutorado) - Faculdade de Ciências Médicas, Universidade Estadual de Campinas. Campinas, 2008b.

SILVA, V. R.; GRADIM, C. V. C. Avaliação da dor em mulheres com câncer de mama submetidas à exérese da rede linfática axilar. Cogitare Enfermagem, Curitiba, v. 15, n. 4, p. 646-51, 2010.

SMELTZER, S. C.; BARE, B. G. Tratado de Enfermagem médico-cirúrgica. 10 ed. Rio de Janeiro: Guanabara Koogan; 2005. v 1.

SOUZA, M. G. G.; ESPÍRITO SANTO, F. H. O olhar que olha o outro. Um estudo com familiares de pessoas em quimioterapia antineoplásica. Revista Brasileira de Cancerologia, v. 54, n.1, p. 31-41, 2008.

STUMM, E. M. F.; MAÇALAI, C.; LEITE, M. T.; LORO, M. M. Mecanismos de coping utilizados por mulheres mastectomizadas para lidar com o estresse. Scientia Medica, Porto Alegre, v. 19, n.3, p. 108-114, 2009.

SZYMANSKI, H. Viver em família como experiência de cuidado mútuo: desafios de um mundo em mudança. Serviço Social \& Sociedade, Franca, v. 17, n.2, p. 09-25, 2002.

TALHAFERRO, B.; LEMOS, S. S.; OLIVEIRA, E. de. Mastectomia e suas consequências na vida da mulher. Arquivos de Ciências da Saúde, São José do Rio Preto, v. 14, n. 1, p. 17-22, 2007.

TAVARES, J. S. C.; TRAD, L. A. B. Metáforas e significados do câncer de mama na perspectiva de cinco famílias afetadas. Cadernos de Saúde Pública, Rio de Janeiro, v. 21, n. 2, p. 426-435, 2005.

TRINCAUS, M. R.; CÔRREA, A. K. A dualidade vida-morte na vivência dos pacientes com metástase. Revista da Escola de Enfermagem USP, São Paulo, v. 41, n. 1, p.44-51, 2007.

VARELA, B.; CAPORALE, B.; DELGADO, L.; VIERA, M.; GALAIN, A.; SCHWARTZMANN, L. Afrontando la posibilidad de tener cancer de mama. Ciencia y Enfermeria, Concepcion, v 13, n. 2, p.33-40, 2007.

VERONESI, U. Mastologia Oncológica. Rio de Janeiro: Medsi. 2002.

VIEIRA, C. P.; LOPES, M. H. B. M.; SHIMO, A. K. K. Sentimentos e experiências na vida das mulheres com câncer de mama. Revista da Escola de Enfermagem USP, São Paulo, v. 41, n. 2, p. 311-316, 2007. 
WEIHERMANN, A. M. C. Usando um referencial cultural para cuidar de mulheres que tiveram câncer de mama. Texto e Contexto Enfermagem, Florianópolis, v. 9, n. 2, p. 673-68, 2000 .

WHO. WORLD HEALTH ORGANIZATION. International Classification of Impairments, disabilities and handicaps: a manual of classification relating to the consequences of disease. Geneve, 1980.

ZIMERMAN, D. E. Fundamentos básicos das grupoterapias. Porto Alegre: Artes Médicas Sul, 2000. Cap. 6 e 7.

ZIMERMAN, D. E.; OSÓRIO. L.C. Como trabalhamos com grupos. Porto Alegre: Artes Médicas, 1997. 
Anexos e Apêndices 


\section{ANEXOS E APÊNDICES}

\section{ANEXO A - APROVAÇÃO DO CEP}

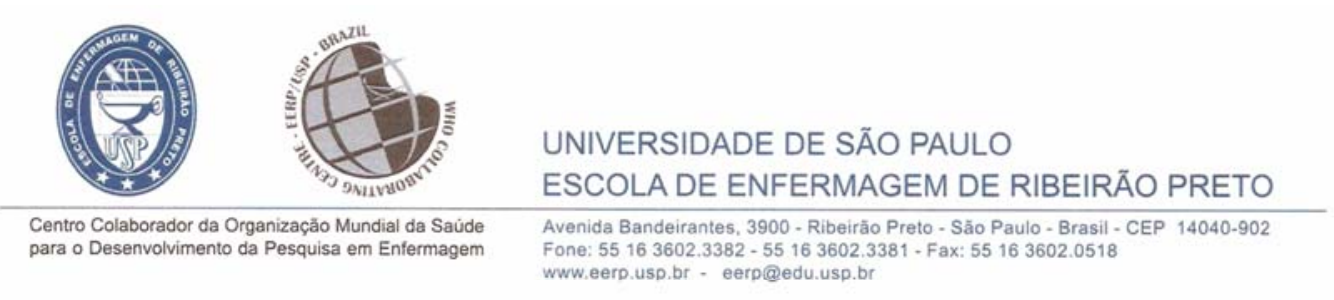

COMITÊ DE ÉTICA EM PESQUISA DA EERP/USP

Of.CEP-EERP/USP - 0194/2010

Ribeirão Preto, 03 de setembro de 2010.

Prezada Senhora,

Comunicamos que o projeto de pesquisa, abaixo especificado, foi analisado e considerado APROVADO AD REFERENDUM pelo Comitê de Ética em Pesquisa da Escola de Enfermagem de Ribeirão Preto da Universidade de São Paulo, em 03 de setembro de 2010.

Protocolo:

$n^{\circ} 1200 / 2010$

Projeto:

$$
\begin{aligned}
& \text { A PERCEPÇÃO DE MULHERES COM CÂNCER DE MAMA } \\
& \text { SOBRE SÜA PARTICIPAÇÃO EM UM GRUPO DE } \\
& \text { REABILITAÇÃO EAPOIO. }
\end{aligned}
$$

Pesquisadores: Marislei Sanches Panobianco

Edilaine Assunção Caetano

Em atendimento à Resolução 196/96, deverá ser encaminhado ao CEP o relatório final da pesquisa e a publicação de seus resultados, para acompanhamento, bem como comunicada qualquer intercorrência ou a sua interrupção.



Profa. Dra. Lucila Castanheira Nascimento Coordenadora do CEP-EERP/USP

IIma. Sra.

Profa. Dra. Marislei Sanches Panobianco

Departamento de Enfermagem Materno-Infantil e Saúde Pública Escola de Enfermagem de Ribeirão Preto-USP 


\title{
ANEXO B - APROVAÇÃO DA COORDENAÇÃO DO MUCAMA
}
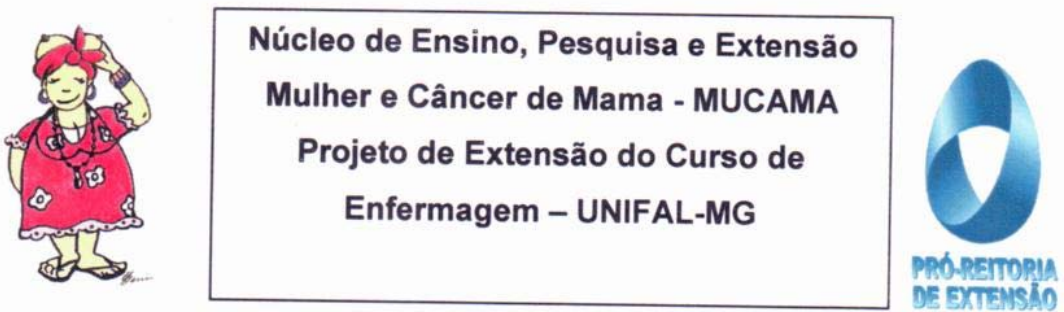

Alfenas (MG), 03 de dezembro de 2010.

\begin{abstract}
Autorização
Eu. Clícia Valim Côrtes Gradim, coordenadora do Núcleo de Ensino, Pesquisa e Extensão Mulher e Câncer de Mama - MUCAMA da Universidade Federal de Alfenas-Mg autorizo a coletada de dados, do projeto de pesquisa intitulado "A influência do grupo de reabilitação de mastectomizadas na vida das mulheres que o frequentam", de responsabilidade da mestranda Edilaine Assunção Caetano, sob orientação da Prof ${ }^{a} \mathrm{Dr}^{\mathrm{a}}$ Marislei Sanches Panobianco vinculado ao Departamento de Enfermagem Materno-infantil e Saúde Pública da Escola de Enfermagem de Ribeirão Preto (DEMISP - EERP/USP).
\end{abstract}

Por ser verdade, assino o presente,

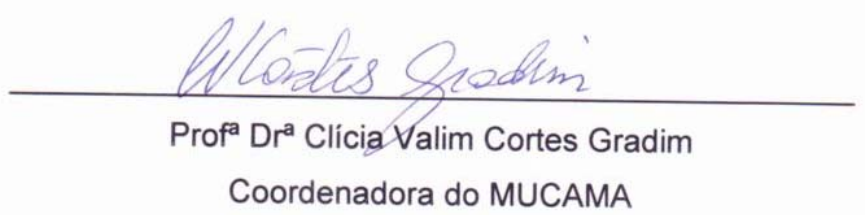




\section{APÊNDICE A - FORMULÁRIO DE COLETA DE DADOS}

Iniciais do nome:

Data de nascimento:

Ocupação:

Escolaridade:

Estado civil:

Tipo de cirurgia:

Data da cirurgia:

Tratamento com Radioterapia ( ) Sim ( ) Não

Há quanto tempo?

Tratamento com Quimioterapia ( ) Sim ( ) Não

Há quanto tempo?

Data de $1^{\circ}$ comparecimento ao MUCAMA:

\section{Questões norteadoras:}

\section{1- SUSCETIBILIDADE}

a) O que o câncer de mama representa em sua vida: ontem, hoje e amanhã.

\section{2- SERIEDADE}

a) Conte-me como você chegou ao MUCAMA: como soube de sua existência e por que veio.

\section{3- BENEFÍCIOS}

a) Que atividades você faz no MUCAMA?

b) Quais atividades você mais gosta ou mais te atrai?

c) De tudo que você faz e aprende aqui, o que você repete em casa, no trabalho ou no lazer?

\section{4- BARREIRAS}

a) Quais atividades que você menos gosta aqui no grupo?

b) Você participa regularmente? E quando falta você poderia me dizer o por quê?

c) Você se sente à vontade quando participa do grupo? Consegue falar, expor tudo que tem vontade?

d) Você se acha diferente aqui e na sua casa com seus familiares e amigos? Me explique melhor.

\section{PERCEPÇÃO DA SATISFAÇÃO}

\section{DEMANDAS E NECESSIDADES}

a) $\mathrm{O}$ que você acha do trabalho dos profissionais?

b) O que você acha do horário de atendimento?

c) O que você acha do número de pessoas?

d) O que você acha do atendimento? 


\section{APÊNDICE B - TERMO DE CONSENTIMENTO LIVRE E ESCLARECIDO}

Você está sendo convidada a participar da pesquisa intitulada "Participação de mastectomizadas em um grupo de reabilitação: benefícios e barreiras percebidos” que tem como objetivo analisar a percepção de mulheres com câncer de mama acerca da seriedade da doença, de sua suscetibilidade a ela e dos benefícios e barreiras para a participação em grupos de reabilitação. Acreditamos que os resultados deste estudo poderão melhorar o seu atendimento e o das outras mulheres que frequentam o MUCAMA. Para participar, você deverá responder a um formulário com dados pessoais, como iniciais do nome, data do nascimento, escolaridade, ocupação, estado civil e às questões relativas ao tratamento do câncer de mama, incluindo as cirurgias e os tratamentos adjuvantes. Deverá, ainda, responder às questões: Por que você procurou o MUCAMA? O que significa, para você, participar do MUCAMA? Conte-me como você considera o câncer de mama em sua vida: ontem, hoje e amanhã. Nossa conversa será gravada e durará em torno de uma hora, nas dependências da UNIFAL-MG, no dia e horário que você achar melhor. As fitas contendo as gravações, em som e imagem, ficarão guardadas sob nossa responsabilidade durante cinco anos e, após esse período, serão inutilizadas. Os resultados deste estudo serão divulgados apenas em artigos e eventos científicos. Sua identidade será mantida em segredo e os dados que julgar secretos não serão revelados. Você poderá recusar o convite ou deixar de participar da pesquisa no momento que desejar. Para participar você não receberá dinheiro, nem terá outros ganhos materiais e também nenhuma despesa financeira nem prejuízo ao seu atendimento no MUCAMA. Caso apresente algum desconforto emocional durante as entrevistas, estarei pronta a confortá-la ou encaminhá-la para atendimento psicológico, se necessário. Você e as pesquisadoras assinarão e ficarão com uma via assinada deste documento.

$\mathrm{Eu}$, concordo em participar da pesquisa realizada pela aluna Edilaine Assunção Caetano, sob orientação da Prof ${ }^{\mathrm{a}} \mathrm{Dr}^{\mathrm{a}}$ Marislei Sanches Panobianco. Endereço e telefone para contato com as pesquisadoras: Av. Bandeirantes, 3900 (Escola de Enfermagem de Ribeirão preto / USP) - (16) 3602-3480, (16) 8819-4528, (35) 9203-0407.

Assinatura

Marislei Sanches Panobianco

Edilaine Assunção Caetano 